\title{
Newspaper Ombudsmanship in Canada: The Rise and Fall of an Accountability System
}

\author{
A thesis submitted to the Faculty of Graduate and Postdoctoral Affairs \\ in partial fulfillment of the requirements for the degree of \\ Master of Journalism, Carleton University.
}

\section{By Carolina Quixadá}

B.A. Communication, Federal University of Ceara (Brazil), 2006

B.A. Communication, University of Fortaleza (Brazil), 2002

(C) Carolina Quixadá, 2010 
Library and Archives

Canada

Published Heritage Branch

395 Wellington Street Ottawa ON K1A 0N4 Canada
Bibliothèque et

Archives Canada

Direction du

Patrimoine de l'édition

395, rue Wellington

Ottawa ON K1A ON4

Canada
Your file Votre référence

ISBN: 978-0-494-79599-6

Our file Notre référence

ISBN: $978-0-494-79599-6$
NOTICE:

The author has granted a nonexclusive license allowing Library and Archives Canada to reproduce, publish, archive, preserve, conserve, communicate to the public by telecommunication or on the Internet, loan, distribute and sell theses worldwide, for commercial or noncommercial purposes, in microform, paper, electronic and/or any other formats.

The author retains copyright ownership and moral rights in this thesis. Neither the thesis nor substantial extracts from it may be printed or otherwise reproduced without the author's permission.
AVIS:

L'auteur a accordé une licence non exclusive permettant à la Bibliothèque et Archives Canada de reproduire, publier, archiver, sauvegarder, conserver, transmettre au public par télécommunication ou par l'Internet, prêter, distribuer et vendre des thèses partout dans le monde, à des fins commerciales ou autres, sur support microforme, papier, électronique et/ou autres formats.

L'auteur conserve la propriété du droit d'auteur et des droits moraux qui protège cette thèse. Ni la thèse ni des extraits substantiels de celle-ci ne doivent être imprimés ou autrement reproduits sans son autorisation.
In compliance with the Canadian Privacy Act some supporting forms may have been removed from this thesis.

While these forms may be included in the document page count, their removal does not represent any loss of content from the thesis.
Conformément à la loi canadienne sur la protection de la vie privée, quelques formulaires secondaires ont été enlevés de cette thèse.

Bien que ces formulaires aient inclus dans la pagination, il n'y aura aucun contenu manquant.

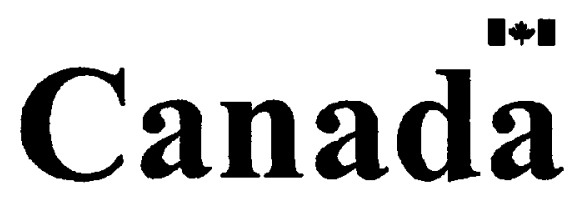




\begin{abstract}
Ombudsmanship is one means of media accountability that newspapers have adopted around the world, yet in small numbers. Of the eleven Canadian papers that have instituted ombudsmanship as an accountability tool in the past, only one still holds the position: the Toronto Star. This thesis examines the rise, roles and demise of newspaper ombudsmanship in Canada. This thesis draws from 76 interviews, including current and former publishers, editors, reporters, and ombudsmen of the eleven papers, along with dozens of columns written by the latter. The findings are examined within the theoretical concepts of ombudsmanship and media accountability. It concludes that ombudsmen served as an adequate, beneficial channel of accountability for the audiences of the publications, but the newspapers are not likely to adopt the system for the foreseeable future, for the same reasons that led to their widespread demise.
\end{abstract}




\section{ACKNOWLEDGMENTS}

I would like to express my thanks to all my interviewees for taking the time to share their recollections with me. This project would have not been possible without their collaboration. Grateful thanks to the School of Journalism and Communication and the Faculty of Graduate and Postdoctoral Affairs, Carleton University, for the generous funding provided.

Thanks to Professor Allan Thompson for the support he extended throughout the course and for his help in putting me in contact with the executive editors of the Toronto Star, where I started my research. Thanks to Professor Jeff Sallot, for whom I had the pleasure of working as a Research Assistant. The inspiration for this thesis arose from interviews I conducted with journalists regarding ethics as part of my tasks as his RA.

My sincere thanks to Professor Peter Johansen for helping me in some many ways in this project. His suggestions guided me not only as a student but also as a researcher and journalist. When I asked him to be my supervisor, I knew I had chosen the best.

Thanks to my MJ2 colleagues for sharing the challenges of this academic path: Gaaki Kigambo, Ebere Ahanihu, Yolande Cole, Amanda Pfeffer, Arthur Asiimwe, Ignatius Kabagambe, and especially Laurie Mackenzie, to whom I felt so connected that I would sometimes speak in Portuguese to her, thinking that she was also Brazilian.

And thanks to my husband, Verilo Sampaio, for keeping the confidence that our "sabbatical year" in Canada, which included the dream of a master's degree, would be all right. That one year became almost five, and we are now a family of four. Our sons, Arthur and Pedro, are certainly the most unexpected and successful part of this great experience abroad. 


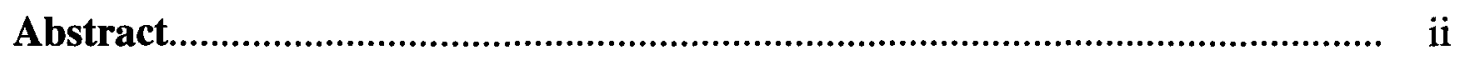

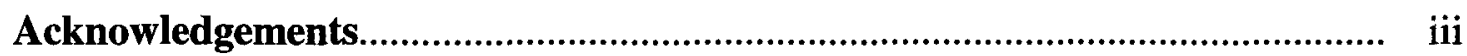

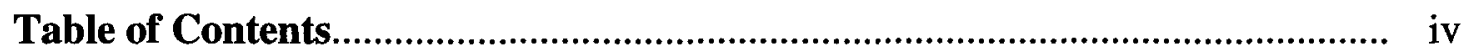

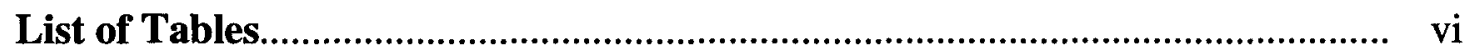

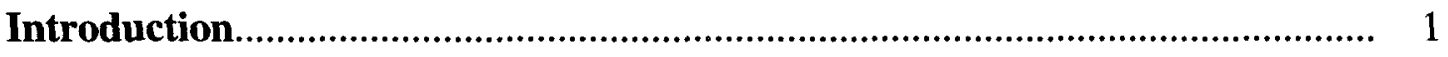

Chapter 1: Media Accountability....................................................................... 7

Accountability as a process $\quad 7$

Responsibility vs. Accountability 9

Public accountability 11

Accountability in business $\quad 12$

News media accountability 14

The power of the news media $\quad 16$

$\begin{array}{ll}\text { Vast audience } & 19\end{array}$

Types and classification $\quad 20$

The vulnerability within the systems 22

Press councils $\quad 23$

Journalism reviews $\quad 26$

Letters to the editor $\quad 27$

Codes of ethics $\quad 27$

Chapter 2: Ombudsmanship....................................................................... 29

A representative called ombudsman $\quad 29$

The news ombudsman 31

The reach and expansion of newspaper ombudsmanship 35

$\begin{array}{ll}\text { The academic research } & 37\end{array}$

The PR thing 38

The in-house critic and its influence on journalism ethics $\quad 43$

The ideal ombudsman and peer surveillance $\quad 44$

Everything but ombudsmen $\quad 46$

Chapter 3: National Context........................................................................... 49

Top executives' motives for ombudsmanship $\quad 52$

Conditions of employment $\quad 61$

Contract $\quad 61$

Unlimited time frame $\quad 65$

Job description $\quad 66$ 
Chapter 4: Who Ombudsmen Are and What They Do........................................ 69

Who are they? $\quad 69$

The tasks $\quad 73$

Columns $\quad 77$

The enforcement part of an ombudsman's job $\quad 78$

$\begin{array}{lr}\text { Frequency } & 81\end{array}$

Topics $\quad 83$

Styles and patterns $\quad 89$

The effectiveness of the position $\quad 95$

$\begin{array}{ll}\text { Other ombudsmen have their say } & 101\end{array}$

Chapter 5: The Fall of Newspaper Ombudsmanship......................................... 106

The reasons for termination 106

Toronto Star ombudsmanship not immune to problems 122

Interruptions in incumbency $\quad 122$

Conflicts 123

Position guaranteed, at least for the moment 130

A new time that came along 131

Chapter 6: Conclusion................................................................................... 134

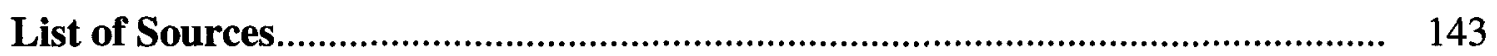




\section{LIST OF TABLES}

Table 1: News ombudsmen worldwide............................................................ 37

Table 2: Canadian newspaper ombudsmanship.................................................... 51

Table 3: Ombudsmen who held the job over four years........................................... 66

Table 4: Canadian papers' circulation at the time they employed an ombudsman.... 72 


\section{INTRODUCTION}

On an early May morning in 2010, a 15-year-old Toronto teen was shot in the face. He died shortly after the incident: a murder. Two city reporters at the Toronto Star wrote about the case that afternoon. Their story appeared on the front page of the paper next day:

Police are investigating a possible gang connection in the shooting death of a 15-year-old boy Monday morning.

The teen was shot in the face around 2 a.m. after he answered the door of an apartment above DJ Records and Clothing at 2508 Eglinton Ave. W. near Keele St.

He was taken to Sunnybrook hospital, where he was pronounced dead, EMS officials said. He would have been 16 on July 17 .

It was Toronto's 16th homicide of the year. ${ }^{1}$

Although police declined to release the victim's name, the reporters identified him later in the story as Devante Beard. They based their identification on witnesses, especially three teenagers who said at the scene the boy had been visiting them for a sleepover when the shooting happened. They also relied on other "friends" of the victim. But the reporters got the boy's name wrong. It was really Devonte Gondwe-Prosper.

Devante Beard, whose name was wrongly identified, and his family had a hell of a time after the episode. The teen went to school, despite the erroneousness of the front page story; but, of course, he didn't have a regular day. He received a massive wave of questions from his colleagues and teachers. "I kept telling them I'm here, I'm alive. It was

\footnotetext{
${ }^{1}$ Denise Balkissoon and Henry Stancu, "Gang connection investigated in killing of boy, 15," Toronto Star, May 18, 2010, p. 1.
} 
very frustrating and I got very annoyed - and I started to feel depressed. I didn't know why the paper would put that in when it wasn't the truth," the boy complained.

His mother, Charmaine Beard, was equally upset. "I had so many people calling me crying, everyone telling me my son is dead. If I had seen that in the paper and not known exactly where my son was, I would have had a nervous breakdown," she said.

The Star learned it had made a serious mistake. Charmaine Beard called Kathy English, the Toronto Star's public editor (or ombudsman, as the post was called for several years), to complain. She was not happy.

English investigated. She talked with many in the newsroom, especially Henry Stancu and Denise Balkissoon, the reporters who wrote the story, and city editor Graham Parley. She immediately wrote a correction for the paper's website. She then wrote an apology, publicized the next day, ${ }^{2}$ and dedicated her weekly column to the episode.

In it, English gave the details of how and why this failure had occurred and the paper's perspective on this "unforgiveable mistake." She also quoted Charmaine and Devante Beard, as cited above. There was an absolute collapse in newsroom communication, as she put it in her column:

Both reporters told me they believed they had communicated to the newsroom that the victim's identity was not yet verified. But a copy editor who spoke with both reporters misunderstood and thought the identity had been properly verified.

What makes this all the worse is that earlier in the day, another Star reporter had contacted Toronto Community Housing media relations manager Jeffrey Ferrier to verify that Beard was the murder victim. Ferrier immediately contacted Beard's mother who informed him that her son was alive and was, in fact, with her at that time.

Ferrier immediately called the Star to inform the newsroom that Beard was not the crime victim. The reporter then sent an email to two city assignment editors informing them of this

\footnotetext{
2 "Apology," Toronto Star, May 19, 2010, p. 2.
} 
important information. But that email came at a very hectic time in the daily newspaper production cycle and was somehow not seen by either editor.

"There was poor communication between reporters and editors that resulted in a piece of unchecked information being inserted into a story," Parley said. "Even then, a warning was passed to editors before publication, but the email was missed."

There was a time when no media outlet would report the identity of a murder victim until it had been officially released by police following notification of next of kin. Increasingly, the Star and other media organizations are seeking to learn such information independent of police verification.

Charmaine Beard questions why the Star did not contact her about her son. It's a fair question. Clearly, more reporting was needed here.

"In the past, we have always had identities confirmed by close friends or family of a victim," Parley said. "This did not happen in this case.

"We will not let this happen again. A big lesson was learned by all involved and our practices will be more rigorous in future," he said. "That means reporters need to be absolutely sure of the bona fides of so-called friends and family, and editors need to know the sources of the information.

"When in any doubt, we will not publish." ${ }^{3}$

In short, English gave an account - an explanation or justification - to readers (and in this case also to the wrongly named boy and his family) for what had happened. This thesis is an examination of ombudsmanship. It is important precisely because of the role ombudsmen have had in making the media accountable.

Although important, Canadian newspaper ombudsmanship isn't as robust as it used to be. Eleven newspapers have employed the position over the years; nowadays only the Toronto Star still does. The ten who dropped it are: the Winnipeg Tribune, the Edmonton Journal, the Ottawa Citizen, the Winnipeg Free Press, the Montreal Gazette, the Halifax Chronicle-Herald, the London Free Press, the Calgary Herald, the Sudbury Star, and the Toronto Sun.

\footnotetext{
${ }^{3}$ Kathy English, "The Star's 'unforgivable' error," Toronto Star, May 22, 2010, p. 6.
} 
This thesis examines why there has been such a decline, shedding light on the factors that led these newspapers to terminate the position. But it also examines the reasons for appointing ombudsmen in the first place, analyses who the ombudsmen were and the tasks they performed, and inspects why the Star still employs such a post.

In summary, this thesis argues that decline occurred because of the circumstances that each newspaper was going through at the time, including among them: 1) budgetary problems that led to downsizing in the newsroom; 2) declining readership engagement with the position, leading to a lack of complaints; and 3) change in the appreciation that top executives had of the job - management thought the role could be handled by other staff, or thought the ombudsman was an undesirable "buffer" between readers and journalists.

The main foundation of this thesis rests on interviews conducted with current and former publishers, executive editors, ombudsmen, and veteran journalists from each of the 11 newspapers. Altogether, I have conducted 76 interviews, which constitute my primary sources.

This thesis also draws from various ombudsmen's columns. I have analysed columns of each of the 27 incumbents that Canada has had so far - the number ranging from a minimum of six to a maximum of 30 per incumbent. I gathered the columns using micro-fiche and online search engines available through Carleton Library. For those columns not available at the university, I used the micro-fiches at Archives Canada. In selecting the columns, I looked for different subjects dealt by each ombudsman, along with their first and last columns as a way of measuring the length of each tenure. 
I also used a number of books and journal articles on the theoretical concept of media accountability and ombudsmanship, mostly from the United States. A few newspaper articles and websites related to the subject were also utilized.

In total, I have written six chapters.

Chapter 1 examines the concept of accountability, and specifically what media accountability is, including the reasons for being accountable. It is within this theoretical concept that ombudsmanship is analysed. Other media accountability systems employed in Canadian newspapers - press councils, journalism reviews, letters to the editor, and codes of ethics - are very briefly explored. The idea is to reveal how each system works and its principal vulnerabilities.

Chapter 2 examines the history of ombudsmanship worldwide: how the concept was created and its purposes, first in governmental agencies and later in newspapers. It also provides some statistics on newspaper ombudsmanship, and explores what the most important academic research on the subject has claimed, such as its function as a public relations device.

Chapter 3 focuses on the Canadian context, exploring the rise of ombudsmanship in the eleven papers and the conditions of employment ombudsmen had. As we shall see in this section, publishers or executive editors of the day named their ombudsmen for a variety of reasons, including official inquiries into the press, awareness of local market monopoly, need for a change in some key newsroom positions, and the avoidance of badtempered readers by publishers.

Chapter 4 brings a portrayal of Canadian newspaper ombudsmen: who they were and what they did, along with an examination of the most common topics and patterns of 
their columns. Here the particularities of Canadian ombudsmanship are compared with the general descriptions of the incumbents and their role worldwide. This section also explores how effective my interviewees feel the position has been, including the opinions of other news ombudsmen from such organizations as the CBC and Washington Post.

Chapter 5 examines the factors that led to the position's termination in ten Canadian newspapers. The main factor was budgetary constraints, but there was also a deep-seated change in what the job was accomplishing over the years. The chapter also studies difficult times that the post has had during its 38-year history at the Toronto Star, and what its future there looks like.

Chapter 6, the conclusion, summarizes the arguments presented, along with final considerations on the findings and implications of my research, and suggestions for future studies on the subject. 


\section{Chapter 1 \\ MEDIA ACCOUNTABILITY}

\section{Accountability as a process}

Newspaper ombudsmanship is one of several means of media accountability; others include press councils, ethics codes and the legal system. But what exactly is media accountability? What does the term imply? What are its functions? What are the reasons to implement any accountability tool? In this chapter I examine these questions, exploring the concept of accountability from its roots. I am going to look as well at the implications of the term and its definitions with respect to the news media specifically.

Accountability is not a simple concept. Many scholars have acknowledged that. Complicating that is the fact scholars tend to examine the concept from differing theoretical approaches, and thus also differ in classifying and evaluating its forms and mechanisms.

But let's start the discussion with the semantic roots of accountability. What is an account? Scott and Lyman define it as a:

linguistic device employed whenever an action is subjected to valuative inquiry. (...) a statement made by a social actor to explain unanticipated or untoward behaviour - whether that behaviour is his own or that of others, and whether the proximate cause for the statement arises from the actor himself or from someone else. ${ }^{1}$

\footnotetext{
${ }^{1}$ Marvin B. Scott and Stanford M. Lyman, "Accounts," American Sociological Review, Vol. 33, No.1, 1968, page 46.
} 
Such devices, the researchers explain, are a critical aspect of human relations because accounts can prevent disagreements by "verbally"2 overcoming the breach between action and expectation.

Fenstermacher writes that there are some "basic" features of accountability that are similar to the definition of accounts above. As he puts it, accountability happens between persons, who must hold regard for some standard of performance. The actors in this relationship must be required to provide or receive information. This obligation can be of two sorts. It can be simply a notification or updating that A makes to B - when banks, for example, publish statements of quarterly assets in local newspapers. Or, second, it can be an explanation, excuse or justification of A's conduct to $\mathrm{B}$ - this is the case, for instance, of congressional investigations into alleged misbehaviour.

Accountability is not only a dynamic process, but also a complex one,

Fenstermacher says:

To analyse the concept thoroughly, it would be necessary to delve into many complexities. For example, it would be necessary to determine how B gains and retains the entitlement to hold A accountable; that is, to determine precisely what it is that brings $\mathrm{A}$ and $B$ into an accountability relation (...) [and] how A and B reach mutual consent on the tasks to be performed and the standards to be met - if indeed such agreements are ever reached. ${ }^{3}$

\footnotetext{
${ }^{2}$ The scholars analyse one feature of talk, the account, and have the objective of explaining why and how excuses and justifications - the two general kinds of accounts, according to them - can counterbalance an act or its cost. Justifications, they write, are "vocabularies that neutralize an act or its consequences... [they are] accounts in which one accepts responsibility for the act in question, but denies the pejorative quality associated with it." Excuses are accounts for mitigating or relieving responsibility when conduct is questioned. It's when "one admits that the act in question is bad, wrong, or inappropriate but denies full responsibility." (Scott and Lyman, "Accounts," pages 47 to 51.$)$

${ }^{3}$ Gary D. Fenstermacher, "Educational Accountability: Features of the Concept," Theory Into Practice, Vol. 18, No.5, 2001, page 331.
} 
Other elements, such as trust and responsibility, count as well. According to the scholar, when we say that B holds A accountable, it is implied that B trusts in A's capabilities to perform a responsible job. He says:

The conferral of trust and responsibility are usually accompanied by discretionary authority - though not always. (...)Yet it is generally the case that when we trust others and are prepared to assign them responsible tasks, we also confer on them the authority necessary to accomplish these tasks. ${ }^{4}$

However, trust, responsibility and discretionary authority are not essential to accountability. As Fenstermacher explains:

A voter may cancel his trust in an elected official, yet still hold this official accountable. A corporate executive could be stripped of authority, but still be held accountable by stock-holders. The oldest sibling may never have been formally charged with the care of the younger children, but may nevertheless be called to account by an upset or angry parent. That trust can be withdrawn, discretionary authority curtailed, and responsibility unassigned, yet accountability still be in force. ${ }^{5}$

\section{Responsibility $v s$. accountability}

There is frequent confusion between accountability and responsibility. Often they are used as synonyms. Among European languages, as Höpfl puts it, "only English seems to distinguish the two by separate words." ${ }^{, 6}$ In some languages, such as Portuguese, there is not even an equivalent word for accountability, complicating its translation.

McQuail offers an explanation for the confusion. He says responsibility and accountability share a common etymology in English and in other languages because they

\footnotetext{
${ }^{4}$ Fenstermacher, "Educational Accountability: Features of the Concept," pages 331 and 332.

${ }^{5}$ Fenstermacher, "Educational Accountability: Features of the Concept," page 332.

${ }^{6}$ Harro M. Höpfl, "The Critical Issue of Accountability," in Critical Theory Ethics for Business and Public Administration, Charlotte, NC: Information Age Pub., 2008, page 138.
} 
are related to the verb answer. ${ }^{7}$ Indeed, as dictionary definitions demonstrate, accountability implies linguistic similarities with responsibility and also with answerability. Merriam-Webster Online Dictionary, for example, defines accountability as "the quality or state of being accountable; especially an obligation or willingness to accept responsibility or to account for one's actions. ${ }^{88}$ Dictionary.com describes accountability as "the state of being accountable, liable, or answerable."

Glasser ${ }^{10}$ and Hodges try to distinguish between the two concepts by writing that we are responsible for, but accountable to. That, according to them, makes all the difference. "Responsibility has to do with defining proper conduct, accountability with compelling it," Hodges writes. ${ }^{11}$

Indeed, Höpfl emphasizes that accountability "always” involves responsibility, while the opposite is not true. He argues that any relationship of accountability requires a couple of questions to be answered:

Who is accountable? To whom? For what? How, or by what procedure? And when? This relationship postulates an agent (the answer to who is accountable?) that has been entrusted by some principal (i.e., a superior in respect of this relationship: accountable to whom?) with a task. It must, moreover, be a task that requires the exercise of discretion, skill, and judgment in the agent's use of the principal's resource or authority (accountable for what?) ${ }^{12}$

\footnotetext{
${ }^{7}$ Denis McQuail, Media Accountability and Freedom of Publication, Oxford: Oxford University Press, 2003.

${ }^{8}$ In Merriam-Webster online dictionary, www.merriam-webster.com/dictionary/accountability (accessed August 15, 2009).

9 In Dictionary.com, www.dictionary.reference.com/browse/accountability (accessed August 15, 2009).

${ }^{10}$ Theodore L. Glasser, "Three Views on Accountability," in Media Freedom and Accountability, New York: Greenwood Press, 1989.

${ }^{11}$ Louis W. Hodges, "Defining Press Responsibility: A Functional Approach," in Responsible Journalism, Beverly Hills, Calif.: Sage Publications, 1986, page 173.

${ }^{12} \mathrm{Höpfl,} \mathrm{"The} \mathrm{Critical} \mathrm{Issue} \mathrm{of} \mathrm{Accountability,"} \mathrm{page} 138$.
} 


\section{Public accountability}

This brings us to the matter of authority or power. What conditions are necessary for authority to exist? Why would individuals or organizations accept others' questions as legitimate, and why would they feel they ought to provide answers? These queries are key elements not only in understanding public accountability, but also media accountability (to be discussed later). After all, the media are governed to some extent by government policy, so are subject to some governmental accountability measures; why do they feel their obligations extend any further?

In a democratic society such as Canada, it seems that public or governmental accountability is the easiest arena of accountability to comprehend. It is readily understood that government and its bureaucratic organizations have duties and tasks to perform related to each of their offices and roles. Citizens elect the government authorities (prime minister or president, mayors, etc.) to act, and the latter ought to give an account to the former for how they have completed the tasks with which they have been entrusted.

In this rationale, Axworthy writes that public accountability is also a question of how to advance democracy. "If citizens do not understand or cannot readily get information on how their representatives have used the power that they have been given, then the legitimacy of the government is deeply affected," he says. ${ }^{13}$

But Schedler states that governmental accountability entails more than information and explanatory aspects. It also holds components of enforcement, the imposition of sanctions:

\footnotetext{
${ }^{13}$ Thomas S. Axworthy, "The Accountability Ladder: Five Steps Toward Democracy," paper prepared for the World Forum on the Democratization of Asia, Taipei, Taiwan, September 15-17, 2005, page 2.
} 
It implies the idea that accounting actors do not just "call into question" but also "eventually punish" improper behaviour and, accordingly, that accountable persons not only tell what they have done and why, but bear the consequences for it, including eventual negative sanctions. ${ }^{14}$

The scholar doesn't discuss the varieties of sanctions that politicians can have - which, of course, will depend on the kind of offense - but he says that public exposure (with its consequent destruction of reputation) is a key tool in the public accountability process. As we shall see next, public exposure is also an important element in both business and media accountability.

\section{Accountability in business}

Can we even say that businesses are accountable? If so, to whom? For what? Why would they be willing to be accountable? And what is the extent to which they are accountable? These broad questions on business accountability are particularly relevant because the media are themselves businesses, and consequently share the characteristics of this category of accountability.

Axworthy acknowledges that there is a special rationale in the accountability of the private sector. Corporations have responsibilities to shareholders or stakeholders, even if "the books" [financial records] are not open to every person who demands to see them, he writes. ${ }^{15}$

However, Zadeck et al affirm that companies should be ethical and account for their ethics because reputation counts in the success of a business enterprise, a conclusion

\footnotetext{
${ }^{14}$ Andreas Schedler, "Conceptualizing Accountability," in The Self-Restraining State: Power and Accountability in New Democracies, London: Lynne Rienner Publishers, 1999, page 15.

${ }^{15}$ Axworthy, "The Accountability Ladder: Five Steps Toward Democracy," page 5.
} 
supported by a number of studies cited in their Building Corporate Accountability. The scholars introduce the rising business practice called Social and Ethical Accounting, Auditing and Reporting (SEAAR), a social auditing tool and accountability mechanism for private business.

Companies are finding, in a growing number of cases, that they need to respond to stakeholder concerns not only by changing their practices, but by being more open in reporting how they have performed against key social, ethical and environmental dimensions of their behaviour and impact. It is a short step from accepting the growing need for companies to account for their social, ethical and environmental performance to recognizing the need for rigorous, comprehensive, and externally verified SEAAR. ${ }^{16}$

SEAAR is complex, but it brings many rewards, including loyalty/productivity from staff and loyalty from customers. ${ }^{17}$

Kaler, who calls for similar auditing practices, adds that these practices can have both positive impact (such as consumer support and profit) or negative (such as when a reported wrongdoing leads to a loss of customers or to reluctance from shareholders to provide investment).

Moreover, Kaler highlights the connection between accountability and social control, which would be equivalent to the elements of enforcement mentioned by Schedler in the preceding section on public accountability. He writes:

Whether we are compelled to or not, the very act of the reporting on our conduct automatically lays us open to blame should our answers be thought to reveal misconduct and that blame is, in

\footnotetext{
${ }^{16}$ Simon Zadec et al., "Why Count Social Performance?" in Building Corporate Accountability: Emerging Practices in Social and Ethical Accounting, Auditing and Reporting, London: Earthscan Publications Ltd, 1997, page 15.

${ }^{17}$ Other reasons to engage in SEAAR: to survive and prosper in society; to influence what people are thinking about the organization, and to know what it is happening within the organization.
} 
itself, a form of punishment. (...) It is certainly the case that the threat of blame will inevitably accompany any reporting on

conduct and that blame is a powerful instrument of social control. ${ }^{18}$

\section{News media accountability}

After this brief discussion of the intrinsic elements of accountability in general, and of public and business accountability in particular, I now consider media accountability per se, the main focus of this chapter. Media accountability is a key concept for better understanding newspaper ombudsmanship, as the latter is one of several accountability systems that has been employed by Canadian newspapers. It is within the context of media accountability that the ombudsman system is going to be analysed.

Pritchard provides a succinct conceptualization:

Media accountability is the process by which media organizations may be expected or obliged to render an account [an explanation or justification] of their activities to their constituents [audience members, advertisers, news sources, peers in other media organizations, and regulatory agencies such as Federal Communications Commission]. ${ }^{19}$

Media accountability is not a simple concept, nor could it be. If accountability alone implies complexities - such as the status of actors, the reasons for A being accountable to $\mathrm{B}$, the conditions under which the process takes place - then media accountability should not be any different.

\footnotetext{
${ }^{18}$ John Kaler, "Responsibility, Accountability and Governance," Business Ethics: a European Review, Vol. 11, No.4, 2002, page 329.

${ }^{19}$ David Pritchard, "The Process of Media Accountability," in Holding the Media Accountable: Citizens, Ethics, and the Law, Bloomington: Indiana University Press, 2000, page 2. The brackets were inserted by me, but the words were taken directly from the author on the same page.
} 
In fact, it carries its own complexities, too. Among the complexities we could cite: the unusual place that news organizations, excluding public service broadcasting, have within the economic system (are they business and/or public service?); the power and responsibilities of news media to society and to some extent to democracy (what are those and who institutes them?); the vast audience with its diverse expectations of news content; and the various types of accountability mechanisms. I do not intend to explore each of these in detail. However, it is important to remind ourselves of every one in order to better understand the circumstances in which newspaper ombudsmanship is embedded.

But first of all, why do news organizations employ means of accountability? What are the benefits of doing such a thing?

According to scholars such as Pritchard, Nemeth, McQuail, and Bertrand, the answer is clear: accountability procedures are related to corporate self-interest of the news media, counting for business success. (This is very like what the business accountability authors mentioned earlier have said.) Media accountability tools can be seen as a form of handling customers' complaints, which eventually will lead to compensation - either financial or in the form of public admiration. They also have the functions of developing the quality of the news product or service and avoiding some harm to an individual or society. ${ }^{20}$

\footnotetext{
${ }^{20}$ For more details see David Pritchard, "The Future of Media Accountability," In Holding the Media Accountable: Citizens, Ethics, and the Law, Bloomington: Indiana University Press, 2000, page 191; Neil Nemeth, News Ombudsmen in North America: Assessing an Experiment in Social Responsibility, Praeger: Westport, Conn, 2003, page 63; Denis McQuail, Media Accountability and Freedom of Publication, page 309; and Claude Jean Bertrand, "The Arsenal of the M*A*S," In An Arsenal for Democracy: Media Accountability Systems, Cresskill, New Jersey: Hampton Press, 2003, page 32; and Media Ethics \& Accountability Systems, New Brunswick, N.J: Transaction Publishers, 2002, page 6.
} 


\section{The power of the news media}

News content is part of and has influence on our lives in various spheres - for work, leisure, education, consumption, etc. Scholars who have tried to delineate the functions of the news media tend to group them into categories. Bertrand, Schudson, and Hodges, for instance, suggest these media functions: 1) to watch the environment by reporting on events that take place around us; 2) to insure social communication by providing forums in which many discussions take place; 3) to provide a broad perception and understanding of the world; 4) to transmit the cultural legacy of a group through media content that can also influence people's lives; 5) to contribute to happiness, since entertainment is indispensable to human beings; and 6) to sell, through advertising that informs people about facts and things, though it also sometimes manipulates them. ${ }^{21}$

In addition, scholars have tried to situate the impact of news content in relation to democracy (or to the functions/importance that news outlets have in democratic regimes). Adam, for example, makes the claim that journalism has been linked with democracy throughout history. He writes:

In tracing the career of journalism in the English-speaking world, it becomes clear that it is intimately connected with the growth of democratic and urban culture. It is impossible to conceive of a modern democratic society without at the same time conceiving of the journalist enmeshed in its political events. ${ }^{22}$

Schudson agrees that journalism is important to democracy: "journalism can provide a number of different services to help establish or sustain representative

\footnotetext{
${ }^{21}$ Bertrand, Media Ethics \& Accountability Systems, pages 14 to 16; Michael Schudson, Why Democracies Need an Unlovable Press, Cambridge: Polity, 2008, page 12; and Hodges, "Defining Press Responsibility: a Functional Approach," pages 19 and 20.

${ }^{22}$ G. Stuart Adam, "The Journalistic Imagination," in Journalism Communication and the Law, Scarborough: Prentice-Hall, 1976, page 7.
} 
government." ${ }^{23}$ And McQuail focuses particularly on the news media function within the election process:

At the core of positive expectation facing the media is their contribution to democratic political processes. They are an essential intermediary (for both parties) between citizens and elected governments. The entire process of democratic election itself depends on several conditions that in turn depend on the media. $^{24}$

Democracy, they argue, demands communication of information to citizens if they are to be free and self-governing. It also demands that no government agency goes without scrutiny - the so-called watchdog function of the press. Democracy demands an independent press, and also an accountable one; after all, power entails duties.

At the same time, scholars acknowledge news organizations are private companies. In Canada, virtually all news outlets are privately owned businesses, the major exception being the $\mathrm{CBC}$. That is why scholars consider news organizations to be mixed enterprises. ${ }^{25}$

Media's social responsibility is hard to define exactly because of this dual nature. Among scholars there is no consensus on its definition, but many have cited the 1947 Commission on Freedom of the Press (the Hutchins Commission) as an important staking of claim for press responsibilities. ${ }^{26}$ In fact, its report is generally regarded as the origin

\footnotetext{
${ }^{23}$ Schudson, Why Democracies Need an Unlovable Press, page 12.

${ }^{24}$ McQuail, Media Accountability and Freedom of Publication, page 6.

${ }^{25}$ Among scholars who observe that news outlets are both an industry and a public service are: Everette $E$. Dennis, "Conclusion," In Media Freedom and Accountability, New York: Greenwood Press, 1989; Hodges, "Defining Press Responsibility: a Functional Approach"; McQuail, Media Accountability and Freedom of Publication; and Schudson, Why Democracies Need an Unlovable Press.

${ }^{26}$ See, for example: Christopher Dornan, "Free to Be Responsible: The Accountability of the Print Media," In Reporting the Campaign: Electoral Coverage in Canada, Toronto: Dundurn Press Limited, 1991; Clifford Christians, "Social Responsibility, Corporate Morality, and Codes of Ethics," In An Arsenal for Democracy: Media Accountability Systems, Hampton Press: Cresskill, New Jersey, 2003; Jo Bardoel and Leen
} 
of the "social responsibility theory" of the media, which says a news organization is a "public trustee" before it is a business. The commission emphasized that freedom of the press is in reality a right of the audience (the public) to be informed.

The commission concluded that to continue to be free, without external interference, the media should be accountable. But it failed to provide a good explanation of how the media could accomplish that. Some also argue that the Commission fell short in shedding light on what media accountability entails or even differentiating it from responsibility. ${ }^{27}$ Dornan notes there is an inevitable tension between media accountability and news media freedom:

This inquiry into accountability of the press is therefore an investigation of contradiction, incongruity and irresolution. It is an exploration of the tension between, on the one hand, the insistence on liberty of public expression and, on the other, the fiat that no authority, in a democracy, may go unchecked. (...) The problem of accountability persists because the press is answerable to no higher authority. But the press cannot be so answerable without compromising its essential freedom. This may be an uncomfortable fact, but it is also a fact of democracy. ${ }^{28}$

Other scholars have also discussed the problematic relation between media accountability and news media freedom. ${ }^{29}$ McQuail tends to have a positive perspective on the subject. He states that a "publication cannot ever be completely without constraint

D'Haenens, "Media Responsibility and Accountability: New Conceptualizations and Practices,"

Communications: The European Journal of Communication Research, Vol. 29, No.1, 2004, Pp. 5-25; Patrick Lee Plaisance, "The Concept of Media Accountability Reconsidered," Journal of Mass Media Ethics, Vol. 15, No.4, 2000, Pp. 257-268; McQuail, Media Accountability and Freedom of Publication; and Nemeth, News Ombudsmen in North America: Assessing an Experiment in Social Responsibility.

${ }^{27}$ Dornan, "Free to Be Responsible: the Accountability of the Print Media," pages 161 and 162; and Plaisance, "The Concept of Media Accountability Reconsidered," pages 257 and 258.

${ }^{28}$ Dornan, "Free to Be Responsible: the Accountability of the Print Media," pages 150 and 181.

${ }^{29}$ See, for instance: Clifford Christians, "Self-Regulation: a Critical Role for Codes of Ethics," in Media Freedom and Accountability, New York: Greenwood Press, 1989; William A. Henry III, "Freedom and Accountability: a Search for Solutions," in Media Freedom and Accountability, New York: Greenwood Press, 1989; Dennis, "Conclusion"; and Glasser, "Three Views on Accountability." 
or consequences" and even though almost all accountability mechanisms make reference to some kind of control, they should not be perceived as control itself.

He writes that media accountability does not diminish the freedom of the communicator and, on the contrary, can enlarge it. This occurs because accountability tools involve balance and access of different voices in the news media, and when they are self-chosen and adhered to, threats of intervention are less likely to be successful. The independence of the media is benefited, in this sense, by more accountability. He proposes:

Accountability can threaten freedom if it is enforced by censorship and repressive measures applied by the state, but in some manifestations it has positive effects. It is even possible to conceive accountability as the alternative, if not the reverse, of censorship and other forms of repression. In any case it is different and the aim should be to reconcile the two principles and try to identify forms of accountability and their implementation that do not restrict and may even promote freedom. ${ }^{30}$

\section{Vast audience}

For accountability to take place, prior expectations must be set between the actors in this process. In the media's case, one of the actors is the public; and even if one defines "public" narrowly as the audience of a particular news outlet, we still find lots of people with differing expectations.

Moreover, "public" can also be sources, advertisers, owners and shareholders of media firms, etc. This variety of potential claimants leads to what Plaisance terms "very subjective calls to account" for any news medium. ${ }^{31}$ The issue seems to be a catch 22 , as Merrill puts it:

\footnotetext{
${ }^{30}$ McQuail, Media Accountability and Freedom of Publication, page 185.

${ }^{31}$ Plaisance, "The Concept of Media Accountability Reconsidered," page 261.
} 
Even if all journalists conform to certain journalistic standards, the question as to whether what they are doing is 'responsible' will exist in the society. The general rules (and exceptions to them) will in the future, as they have been in the past and are today, have their proponents and opponents. There is no way in a free and open society to settle this question of press responsibility. A free press will be responsible to some people in some circumstances and to some degree. And, likewise, it will be irresponsible. ${ }^{32}$

Yet, claimants' diversity can get even more multifaceted. For instance, we can ask to whom within the audience the news media will respond first. Nemeth argues that newspapers tend to respond first to those readers who have higher status in society and higher levels of education. They know, for instance, how to articulate a complaint effectively. "The news media in general are solicitous of the powerful," he concludes. ${ }^{33}$

\section{Types and classification}

Regardless of these difficulties, the news media employ several kinds of accountability tools, especially in the United States, Canada and many European countries, according to Bertrand. ${ }^{34}$

In fact the scholar registers more than 60 types, such as codes of ethics, correction boxes, journalism reviews, ombudsmen and press councils. The list also includes less direct forms of accountability, such as higher education, opinion surveys on the media, and media literacy campaigns to educate and mobilize the public. Calling them $M^{*} A * S$ (meaning media accountability systems), Bertrand says these nongovernmental means are used to insure that media "provide public good." He writes:

\footnotetext{
${ }^{32}$ John C. Merrill, "Three Theories of Press Responsibility and the Advantages of Pluralistic Individualism," In Responsible Journalism, Beverly Hills, Calif.: Sage Publications, 1986, page 54.

${ }^{33}$ Neil Nemeth, "How a Typical American Newspaper Handles Complaints," in Holding the Media Accountable: Citizens, Ethics, and the Law, Bloomington: Indiana University Press, 2000, page 52.

${ }^{34}$ Bertrand, Media Ethics \& Accountability Systems; and "The Arsenal of the M*A*S."
} 
$\mathrm{M}^{*} \mathrm{~A} * \mathrm{~S}$ are expected to achieve their purpose by increasing the competence of journalists; by discovering (through observation and analysis) what media do and don't do, as compared to what they should do. And, mainly, $\mathrm{M}^{*} \mathrm{~A}^{*} \mathrm{~S}$ enable media to hear consumers' views, what they like, dislike, might like. And they enable media to discover, correct, explain their errors and mistakes, and apologize for them. $\mathrm{M}^{*} \mathrm{~A} * \mathrm{~S}$ are a mix of quality control, customer service, continuing education - and much more, certainly not just selfregulation. $^{35}$

Although $\mathrm{M}^{*} \mathrm{~A} * \mathrm{~S}$ are intended to increase the quality of journalism, Bertrand fails to show exactly how each system reflects an accountability process per se. That is, he doesn't take into consideration the basic elements of accountability in claiming that each of these are true examples of $\mathrm{M} * \mathrm{~A} * \mathrm{~S}$. Consider higher education (a university degree), for example. How does it offer an accountability system to the media? Who are the actors in this supposed accountability process? Who are the students accountable to? Who are the professors accountable to? What of the school administrators? At least on the face of things, the students are accountable to their professors, the professors are accountable to their supervisors, and the supervisors are accountable to the state, if the school is state run, or their trustees.

We can certainly understand Bertrand's point that a university degree is able to increase the competence of journalists, preparing them with news gathering and writing skills. Similarly, it is clear how an opinion survey can tell media what their consumers like most. But neither of these examples appears to fulfill the criteria that collectively define media accountability tools - who is accountable, to whom, for what, in which circumstances. Yet Bertrand is cited as an important scholar in proposing and discussing what quality journalism should be.

\footnotetext{
${ }^{35}$ Bertrand, "The Arsenal of the $M^{*} A * S$," page 17.
} 
The scholar classifies $\mathrm{M}^{*} \mathrm{~A} * \mathrm{~S}$ into three groups: 1 ) documents, such as written codes of ethics, correction boxes, and letters to the editor; 2) people, including groups like ethics committees and press councils, and individuals like ombudsmen; and 3) processes (long or short), such as higher education degrees, individual courses on media ethics, or regular opinion surveys. However, he notes that other classifications are possible. ${ }^{36}$ And, in fact, scholars apply different ones. According to McQuail, for example, three points should be observed in any categorization: the degree of voluntarism that is involved in the method; its external-internal aspect (does the process involve public or just peer scrutiny?); and its material dimension (whether decisions can be assessed by a third party and result in a penalty, especially monetary, as in lawsuits).

\section{The vulnerability within the systems}

Independent of the classification, scholars agree that no mechanism of media accountability is completely efficient, nor can it be. They all have their fragilities.

Bertrand, for instance, details the troubles with many accountability tools available to news organizations, including the legal system and the market. The former, he notes, although able to offer quick efficient protection against the "power of corporate giants," tends to favour the interests of the elites. The latter, despite some positive influences on the media, forces owners to focus on making money first, which means they do not necessarily act in accordance with the public interest; an example might be compromising the news gathering process by yielding to press releases or the pressures of advertisers or politicians. Bertrand asks:

\footnotetext{
${ }^{36}$ Among these are: 1) who is involved in the process (people within the medium, people external to the media, or both); 2) the level at which the systems operate (national, regional or local); and 3) method (criticism, feedback or training).
} 
Can you put total trust in the law? Can you put total trust in the market? Can you trust both combined? Of course not. Whatever the failings and insufficiencies of ethics and $M * A * S$, there is no choice. Thousands of words have been written and spoken to denounce free market or the law or ethics and $M^{*} A^{*} S$ - and many of the accusations are justified. But then what? Should we just sit and weep? ? $^{37}$

In reality, revealing the problems of specific accountability mechanisms can help in identifying solutions. As Pritchard (2000) puts it, "the first step in improving a system is to learn about its flaws. The next step is to build on the knowledge of a system's flaw to propose reforms." 38

Ombudsmanship has certainly its share of weaknesses, to be observed especially in the next two chapters. Meanwhile, we shall take a very brief look at some of the problems of four other systems employed by Canadian newspapers: press councils, journalism reviews, letters to the editor, and ethics codes.

\section{Press councils}

In Canada press councils were set up in the early 1970s and 1980s on a provincial or regional basis, Saskatchewan being the only exception. In total there are six press councils: Ontario (1972); Alberta (1972); Quebec (1973); Atlantic, which includes New Brunswick, Nova Scotia, Prince Edward Island and Newfoundland (1980); British Columbia (1983); and Manitoba (1983).

A council's main role is to consider complaints about the conduct of the press, trying to render accounts to the public. In general, councils meet three times a year; their membership includes both public and media people. Their power resides in "moral

\footnotetext{
${ }^{37}$ Claude Jean Bertrand, "Conclusion," in An Arsenal for Democracy: Media Accountability Systems, Cresskill, New Jersey: Hampton Press, 2003, page 396.

${ }^{38}$ Pritchard, "The Future of Media Accountability," page 8.
} 
condemnation," that is to say, in publicizing council rulings by the newspaper concerned in cases where the complainant is considered right. Their authority arises from public confidence in their fairness and impartiality. ${ }^{39}$

On the negative side, a press council's hearing process is slow, and the public is not often aware of their existence, as Christina Spencer, a professional member of the Ontario Press Council, observes:

The complaint comes into the press council and the first thing that the press council does is it sends the complaint to the newspaper because the newspaper has to be given an opportunity to resolve the problem. If the newspaper doesn't resolve the problem to the satisfaction of the person who is complaining, then the press council executive committee will take a look at the complaint and determine whether or not we are going to have a hearing. A lot of times we don't have a hearing. A lot of times the council will look at a complaint and say "This is not in our mandate" or "it is absurd," like a comment that a columnist should not be allowed to publish on something. They only do hearings three times a year. So that means it can be months before a complaint gets heard. The actual process of hearing a complaint, it is fairly simple, but there is this real time matter. But most newspapers will meet the deadlines, and show up at the hearings. And the reason they do is that if they lose, they have to publish the results, the judgment. Papers don't like to have to run what they have done wrong so they will take the exercise seriously to go to the press council.

Generally speaking, people who pursue a complaint as far as the council are usually very satisfied with the outcome, even if they don't win the case. If they lose, at least, they feel that someone had heard them and took them seriously. Lots of people don't know that it is there. Another problem is that they can take a long time to correctly point out [that a mistake was made]. ${ }^{40}$

\footnotetext{
${ }^{39}$ Bertrand, Media Ethics \& Accountability Systems, pages 127 to 129; and David Pritchard, "Structural Flaws in Press Council Decision-Making," in Holding the Media Accountable: Citizens, Ethics, and the Law, Bloomington: Indiana University Press, 2000, pages 90 to 92 . According to Pritchard, the impartiality is related to who sits on and who funds the councils.

${ }^{40}$ Christina Spencer, telephone interview, 30 Sep 2009.
} 
The timing issue, at least, is being discussed. Chairman Robert G. Elgie states the Ontario council is going through a renewal process and one of the steps will be to quicken the pace of hearing complaints:

Our constitution allows us to meet three times a year. We try to base our hearings around those three times of the year. The complaints get to be heard within three months usually. But many of my colleagues on the council think that is not quick enough, so we are now in a process of developing ways to shorten the time for those hearings. And like the newspaper industry, there are budgetary issues involved and we may start to do a lot more things by teleconference on the phone, not necessarily with hearings, although that might be necessary. We have tried to think of other ways that allow us to speed up the hearing process. ${ }^{41}$

The Ontario Press Council is the biggest in Canada with a membership of 228 newspapers (37 dailies and 191 community papers) at the beginning of $2009 .^{42}$ It also handles the most complaints: in 2007, there were 100 complaints, and 104 and 103 in 2008 and 2009 respectively. ${ }^{43}$

The British Columbia Press Council has handled 906 complaints and held 57 formal hearings since its creation in 1983. Executive Director Rollie Rose reports that, on average, the council handles 36 complaints per year. "We have never had an occasion where a member newspaper has failed to cooperate with the Press Council. Members do not always like the findings of the Council, but they always comply," adds Rose. ${ }^{44}$

\footnotetext{
${ }^{41}$ Robert G. Elgie, telephone interview, 30 Nov 2009.

${ }^{42}$ Membership also includes newspapers that are published twice or thrice weekly or monthly.

${ }^{43}$ According to Mel Sufrin, Ontario Press Council executive secretary, email interview, 14 Apr 2010.

${ }^{44}$ Rollie Rose, email interview, 25 Mar 2010.
} 
This also seems to be the case of the Alberta Press Council, according to Colleen Wilson, its executive secretary-treasurer: all newspaper members collaborate. In 2008, the council received 23 complaints, and 345 in total since $1972 .{ }^{45}$

\section{Journalism reviews}

Journalism reviews provide accountability by publishing articles that explain why a story was told the way it was or why there was a change in a newspaper operation or procedure. While they are often critical of the media, the articles are usually written and read by professional and student journalists; the general audience is not reached as a rule.

Bertrand ${ }^{46}$ calls reviews an informal network of media accountability since they are usually the product of a small group lacking funds. Nevertheless, he says they are welcomed because they try to expose the sins and perils of the press. On the other hand, Bunton ${ }^{47}$ writes there is not much evidence about the influence of reviews on the practice of journalism; studies usually concentrate on their tone of criticism instead.

Examples of Canadian journalism reviews include: The Ryerson Review of Journalism, founded in 1983 and published twice a year by final-year students in the magazine stream at the School of Journalism, Ryerson University, Toronto; and the online Canadian Journalism Project (CJP), produced since 2007 by the Canadian Journalism Foundation along with journalism schools and organizations across Canada. ${ }^{48}$

\footnotetext{
${ }^{45}$ Colleen Wilson, email interview, 25 Mar 2010.

${ }^{46}$ Bertrand, Media Ethics \& Accountability Systems, pages 125 to 127.

${ }^{47}$ Kristie Bunton, "Media Criticism as Professional Self-Regulation," in Holding the Media Accountable: Citizens, Ethics, and the Law, Bloomington: Indiana University Press, 2000.

${ }^{48}$ The Canadian Journalism Project's websites are: www.j-source.ca and www.projetj.ca, respectively the English and French versions (accessed July 15, 2010).
} 


\section{Letters to the editor}

While the primary function of the letters to the editor is to provide a forum of opinions on political, economic and social affairs, the section also allows readers to comment on the paper's treatment of stories. The section is usually well read, and virtually all Canadian daily newspapers have one. However, space is limited and selection and editing depends upon an editor. Moreover, newspapers do not necessarily respond or make comments related to those letters. Readers also often lack awareness of how to write a letter or how short it should be. Many Canadian ombudsmen indeed have dedicated one or two columns to explain how to write a letter to the editor. ${ }^{49}$

\section{Codes of ethics}

Codes reflect journalistic principles but usually are considered guidelines only. They cover standards of practice and/or the "don't dos" for journalists, such as receiving a bribe or publishing a story with a conflict of interest. Many newspapers in North America have a code of ethics, but do not make them public, fearing that they can be used against the papers in court. ${ }^{50}$ Indeed many Canadian newspapers, such as the Toronto Star, Ottawa Citizen, Globe and Mail and Montreal Gazette, acknowledge that they have a code of ethics, but do not publish it. ${ }^{51}$

\footnotetext{
${ }^{49}$ See, for instance, the columns of Robert Walker, "Improve the chances that your letter will be printed," Montreal Gazette, Feb. 19, 1996, p. B3; "How to improve the chances that your letter will be printed," Montreal Gazette, Sep. 12, 1994. p. B3; Alison Downie, "Want to see your letter in the Sun?" Toronto Sun, Dec. 11, 2005, p. C3; Roger Edge, "Keep those letters coming - but be patient," Chronicle Herald, Feb 11, 2000, p. C2; Chris Krejlgaard, "Is Star's Sunthetic coverage biased?" Sudbury Star, Dec. 11, 1992, p. 6; and John Brown, "Letters a reflection of public opinion," Edmonton Journal, May 10, 1993, p. A8.

${ }^{50}$ Bertrand, Media Ethics \& Accountability Systems, pages 41 to 43.

${ }^{51}$ This is based on requests made to the Ottawa Citizen, Globe and Mail and Montreal Gazette to have access to their codes. Those requests were made while I was working as a Research Assistant to Professor Jeff Sallot at Carleton University in the Fall/Winter of 2008. And while I was conducting personal interviews at the Toronto Star, in June of 2009, I had access to their code, but was notified that its content was not public.
} 
Many scholars, such as Bertrand and Christians, consider codes as a tool of media accountability because they exert a moral pressure on journalists. The two scholars also believe that codes are important because they make ethical norms concrete, create an organizational conscience, and inspire moral awareness. ${ }^{52}$ Yet their impact on journalists' actions is not consistently known. Boeyink, for instance, studied the role of codes of ethics in three newsrooms in the U.S. and concluded the actual influence they have on behaviour will depend on the newsroom environment. ${ }^{53}$

Overall, there is no single pathway to understanding or evaluating media accountability tools. To advance meaningful discussion, it seems necessary to consider the successes and the flaws (as Pritchard proposes) of a particular mechanism and investigate it in a particular society or context. This thesis does exactly that, in this case through assessment of newspaper ombudsmanship in Canada. But before entering the Canadian context specifically, we shall discuss the history of ombudsmanship in general and literature related to newspaper ombudsmanship in particular.

\footnotetext{
${ }^{52}$ Bertrand, Media Ethics \& Accountability Systems; and Christians, "Social Responsibility, Corporate Morality, and Codes of Ethics."

${ }^{53}$ David E. Boeyink, "How Effective Are Codes of Ethics? A Look at Three Newsrooms," Journalism Quarterly, Vol. 71, No. 4, 1994, page 901.
} 


\section{Chapter 2 \\ OMBUDSMANSHIP}

\section{A representative called ombudsman}

The origin of ombudsmanship goes back three centuries. Swedish King Charles XII appointed an officer, a Chancellor of Justice, in 1713 to ensure that laws and statutes were pursued and that royal servants executed their obligations. Sweden was in tumult and Charles XII, who was in Turkey in self-exile for several years, had made the appointment in response to that moment. It became an enduring part of the government. ${ }^{1}$

In 1809 a new Swedish constitution came into place and defined the need for another watchman, but this time from and for the legislative side. His official name is Riksdagens Justitieombudsman, which means "Parliamentary Ombudsman for Justice" or "Parliamentary Agent for Justice". ${ }^{2}$ The first Swedish ombudsman was elected and assumed office on March 1,1810, with the task of monitoring laws and regulations by public officials and taking legal action against those who had committed offenses or neglected their obligations. The duties of the job have evolved, but its main idea is that the ombudsman will try to protect the public against "administrative malfeasance."3

Scholars point out that the ombudsman concept started to become known and adopted elsewhere only after World War II. Lundvik, for instance, says that it was when

\footnotetext{
${ }^{1}$ Frank Stacey, Ombudsmen Compared, Oxford: Clarendon Press, 1978; and Ibrahim Ismail Wahab, The Swedish Institution of Ombudsman: An Instrument of Human Rights, Stockholm: LiberFörlag, 1979. ${ }^{2}$ According to Wahab, the word ombudsman in Swedish has different meanings, but has been usually used as "representative, agent, delegate, lawyer, guardian or any other person who is authorized by others to act on their behalf and serve their interest." (The Swedish Institution of Ombudsman: an Instrument of Human Rights, page 19.)

${ }^{3}$ Ulf Lundvik, The Ombudsmen in the Provinces of Canada, Edmonton, Alta.: International Ombudsman Institute, 1981, page 1.
} 
the first Danish ombudsman assumed the job on April 1, 1955 that the office began to be scrutinised overseas. The ombudsman was Stephan Hurwitz, a former professor, who wrote articles about the office in English, went to England to lecture about it, and appeared on television a couple of times. The new idea had a particular reception in Great Britain at that time (1967), but other countries had already established the office, such as New Zealand (1962), Guyana (1966) and Tanzania (1966). It was in New Zealand, according to Lundvik, that the office developed most, and its model was copied by many countries, including Canada. ${ }^{4} \mathrm{He}$ adds:

Like Great Britain and other developed countries, Canada in the $20^{\text {th }}$ century experienced an enormous growth in the range and complexity of government activities. The public service expanded greatly both on the federal level and in the provinces. More and more of discretionary powers were given the authorities and their decisions affected the rights of the citizens in a way hitherto unknown. 5

The concept became a main topic in the 1960 s in this country, especially after a visit by the New Zealand ombudsman in 1964 and his lecture to the Canadian Bar Association. Donald C. Rowat, a professor of political science at Carleton University, became the main advocate for the introduction of the system in the country. ${ }^{6}$

\footnotetext{
${ }^{4}$ The concept was always adapted by the countries to best suit their culture, political structure, population and size. Differences, Wahab affirms, come in the power, duties, status with the State, procedure and methods of appointment. But all ombudsmen seem to share one feature: "that they deal with complaints and grievances of people and exercise supervision over public authorities and their officials." (Wahab, The Swedish Institution of Ombudsman: An Instrument of Human Rights, page 150.) ${ }^{5}$ Lundvik, The Ombudsmen in the Provinces of Canada, page 6.

${ }^{6}$ Lundvik also affirms that Hugh Thorburn, professor of political studies at Queens University published an article "An ombudsman for Canada?" in the Canadian Forum (June, 1960). He described the ombudsman office in Sweden, Finland, and Denmark and asked if the same should be adopted in Canada. But Lundvik says that Rowat's articles were more numerous and substantial. Besides, the scholar affirms, Rowat had also visited New Zealand for a couple of months to observe the operation of the office there. (The Ombudsmen in the Provinces of Canada, pages 6 to 8.)
} 
Nowadays, the ombudsman concept is pretty much adopted in Canada. Nine provinces (the exception is Prince Edward Island) and one territory (Yukon) have an ombudsman. Their primary duty is to investigate complaints about services provided by government agencies and organizations and, when appropriate, recommend some form of remedial action. ${ }^{7}$ According to the Forum of Canadian Ombudsmen (FCO), besides government departments and organizations, many Canadian universities, colleges, hospitals, banks and other private organizations also have ombudsmen. ${ }^{8}$

But what about news ombudsmen? When was the concept first employed in a news organization? And with what purposes? That is what we shall consider in the next section.

\section{The news ombudsman}

Sweden was once believed to be the first country to introduce the idea of ombudsmanship to the news media, employing it in a Press Council in $1916 .{ }^{9}$ But Nemeth credits the act of ombudsman-like functions to Isaac D. White as director of the Bureau of Accuracy and Fair Play of the New York World, a job he held from 1913 to

\footnotetext{
${ }^{7}$ The title ombudsman or ombudsperson is used in all provinces with exception of Quebec (Protector du Citoyen) and Newfoundland (Citizen's Representative). In most provinces the ombudsman is appointed by the Lieutenant Governor upon the recommendation of the Legislative Assembly.

${ }^{8}$ Canada has three other major associations: the Canadian Ombudsman Association (COA), composed of legislative ombudsman offices in eight provinces and specially ombudsman offices at the federal level; the Association of Canadian College and University Ombudspersons (ACCUO); and the Federal Ombudsman Forum (FOF), with legislative and executive ombudsman offices at the federal level. For more details see: FCO's website (www.ombudsmanforum.ca).

${ }^{9}$ Discussions of the origins are found, for instance, in: Susana H. Damas, "Situacion Del Ombudsman en el Mundo," Revista de Comunicacion, Vol. 4, 2005, Pp. 17-37; Linda Raymond, "We Were Wrong," In www.newsombudsmen.org/raymond, accessed March 29, 2009; and Takeshi Maezawa, "The Controversy Over the Origins and Functions of Ombudsmanship," In www.newsombudsmen.org/maezawa, accessed March 29, 2009.
} 
1931. White, along with two associates, investigated and answered complaints from readers, and prepared corrections to be published. ${ }^{10}$

The Bureau's idea was copied by three other newspapers within a year of implementation: the Philadelphia Ledger, Minneapolis Tribune and Sacramento Bee. The idea must have also had some influence on other newspapers, including the Toronto Star, which created its "Bureau of Accuracy" in 1959.

The Canadian paper announced the beginning of its bureau as a service that would ensure the "highest standards of journalistic integrity and fairness." It would offer readers a watchdog that could be easily accessed by telephone or mail. "If the complaint is justified, a correction will be made as fast as possible. If the complaint turns out to be illfounded, you will be notified promptly," stated the announcement. ${ }^{11}$

Nevertheless, it seems that the Toronto Star's bureau didn't achieve much effectiveness in its opening decade or so. ${ }^{12}$ When Mark Harrison was announced to "represent public in newsroom" in 1972, it was said that his job would involve supervising sections where reader complaints and views were already handled, such as the Bureau of Accuracy and Star Probe (an action line column to solve readers' problems

\footnotetext{
${ }^{10}$ According to Neil Nemeth, White was the most famous crime reporter in New York of his time. After retiring from reporting, White became the head of the legal department of the World in 1910 even without formal education for that. Three years later the paper created the Bureau of Accuracy and Fair Play: "The bureau was to receive complaints about news coverage, seek answers to the questions posed by readers and see corrections be published when necessary." White didn't write public columns. He retired when the World was merged with the New York Telegram in 1931, but Nemeth doesn't say if the Bureau's activities also wrapped up at the same time. ("From Reporting Sleuth to Pioneer in Media Accountability: the Career of the New York World's Isaac D. White," American Journalism, Vol. 25, No. 3, 2008.)

11 “Accuracy first' Star police begins today," Toronto Star, Oct. 13, 1959, page 3.

${ }^{12}$ All Star ombudsmen were announced (with varying emphasis) as the head of the Bureau of Accuracy, and the paper's website still makes reference to the office. (In www.thestar.com/contactus, accessed July 12, 2010.)
} 
as consumers). ${ }^{13}$ Harrison acknowledged that before his post as ombudsman was put into place, the readers' complaints procedure was not well organized:

One of the first things it [the position] did was to formalize the complaint-taking process. Before me if someone called the Star they would have to talk to a girl on the switchboard. Then she would guess who could respond to it. It was a poor arrangement. ${ }^{14}$

Although the Philadelphia, Minneapolis and Sacramento papers each established a bureau of accuracy, they did not claim to have started ombudsmanship in the 1920s.

Neither did the Toronto Star in the late 1950s. Maybe these papers' bureaus were not very effective - perhaps because they lacked a particular person to handle complaints, as Harrison suggests in the Star's case - even if the bureaus' main mandate was to receive and answer reader complaints, the same as an ombudsman does. ${ }^{15}$ In any case, the official creation of the first newspaper ombudsman - or at least the role attributed to a specific person within the newsroom - is said to have occurred in the United States in 1967, when John Hershenroeder was appointed at the Louisville, Kentucky newspapers, the CourierJournal and the Times. He was their ombudsman for 12 years. ${ }^{16}$

The idea was suggested in March 1967 by media critic Ben H. Bagdikian, who proposed a community ombudsman for newspapers in an article in Esquire. ${ }^{17}$ Three

\footnotetext{
13 "Editor to represent public in newsroom," Toronto Star, May 6, 1972, page 1.

${ }^{14}$ Interview cited in Katherine M. Harding, "Death of Newspaper Ombudsmen: Why Canadian Newspapers Have Abandoned Their Watchdogs," Master's Research Project, Carleton University, April 2001, page 20.

${ }^{15}$ "Star readers will now have their personal representative in the newsroom," Beland Honderich said in the article on Harrison's announcement. ("Editor to represent public in newsroom," page 1.)

${ }^{16}$ Hershenroeder would listen to and try to resolve readers' complaints, and write internal memos to staff. He wrote a column only a couple of times during his tenure. For more details see Neil Nemeth, "A news ombudsman as an agent of accountability," in Holding the Media Accountable: Citizens, Ethics, and the Law, Bloomington: Indiana University Press, 2000, page 24.

${ }^{17}$ Bagdikian wrote: "Some brave owner someday will provide for a community ombudsman on his paper's board, maybe a non-voting one, to be present, to speak, to provide a symbol and, with luck, exert public interest in the ultimate fate of the American newspaper." ("The American Newspaper is Neither Record,
} 
months later, a New York Times Magazine article written by A. H. Raskin, then the paper's assistant editorial page editor, urged that the press have a "department of internal criticism." He wrote:

The department head ought to be given enough independence in the paper to serve as an ombudsman for the readers, armed with authority to get something done about valid performance of all the paper's service to the community, particularly the patrol it keeps on the frontiers of thought and action. ${ }^{18}$

Norman Isaacs and Barry Bingham, respectively executive editor and owner of Louisville's Courier-Journal and Times, bought the idea and employed it in the two papers within a month of Raskin's article. ${ }^{19}$

The Washington Post adopted the position in 1970, the second American newspaper to do so. However, Philip M. Foisie, then foreign editor of the Post, suggested some modifications. The ombudsman for the paper would be an outsider working on a fixed contract, but the paper would retain the right to approve each of his or her columns

\footnotetext{
Mirror, Journal, Ledger, Bulletin, Telegram, Examiner, Register, Chronicle, Gazette, Observer, Monitor, nor Herald of the Day's Events," Esquire, March, Issue 124, 1967, Pp. 138-142.) Bagdikian would later clarify his thoughts, writing: "appoint a full-time ombudsman on the paper or broadcasting station to track down complaints about the organization's judgement and performance." ("Right of Access: a Modest Proposal," Columbia Journalism Review, Vol. 8, No. 1, 1969, Pp. 10-13.) Both articles are quoted by Neil Nemeth, News Ombudsmen in North America: Assessing an Experiment in Social Responsibility, Praeger: Westport, Conn., 2003, page 23.

${ }^{18}$ Raskin, "What's wrong with American newspapers?" New York Times Magazine, Jun. 11, 1967 (quoted by Neil Nemeth, News Ombudsmen in North America: Assessing an Experiment in Social Responsibility, page 31).

${ }^{19}$ According to Nemeth, Isaacs and Bingham were already trying to create a press council in the Louisville area. Because they found great resistance from other media organizations, an ombudsman was a suitable alternative way of making the newspaper more accountable. (Nemeth, "A News Ombudsman as an Agent of Accountability," in Holding the Media Accountable: Citizens, Ethics, and the Law, Bloomington: Indiana University Press, 2000, page 56.)
} 
before publishing it. ${ }^{20}$ In Canada, as noted, the Toronto Star was first to adopt the post, in 1972 , the circumstances of which will be discussed in chapter 4 .

It is worth noting that the Swedish term ombudsman is the terminology by far most utilized by papers (and among media scholars). However, other nomenclatures, such as reader's advocate, reader's representative or public editor are also commonly used. The word is presumably gender free. All Canadian newspapers, but one (Toronto Sun "readership editor"), employed the term ombudsman, although the London Free Press and Toronto Star changed the name along the way, in 1991 and 2005, to "readers' advocate" and "public editor" respectively.

\section{The reach and expansion of newspaper ombudsmanship}

The concept of newspaper ombudsman in North America spread in the 1970s, 1980s and 1990s, probably reaching a maximum of 40 appointments in the 1980s and early 1990s. ${ }^{21}$ But the exact number of ombudsmen in North America or worldwide, in either past or present, is hard to determine.

The best option is to turn to the data of the Organization of News Ombudsmen (ONO), a U.S.-based institute formed in 1980 to promote ombudsmanship worldwide. Its members are mostly from the United States, even though the institution was founded at the suggestion of a Canadian, John Brown, then the Edmonton Journal's ombudsman. ${ }^{22}$

\footnotetext{
${ }^{20}$ The first ombudsman for the Post was Richard Harwood, a national correspondent and editor there. For more details see: Nemeth, "A News Ombudsman as an Agent of Accountability," page 24; and also "Philip M. Foisie's Memos to the Management of the Washington Post," in www.newsombudsmen.org/foisie, accessed October 16, 2009.

${ }^{21}$ The numbers of ombudsmen vary among scholarly studies, for reasons outlined in the next paragraphs.

${ }^{22}$ According to Gina Lubrano, ONO's former executive secretary, the institution was first called the Organization of Newspaper Ombudsmen, but became Organization of News Ombudsmen to accommodate broadcast. She also says that ONO started international [non-U.S. and non-Canadian]
} 
As of March 2010, there were 17 U.S. newspapers listed employing an

ombudsman. ${ }^{23}$ Internationally, approximately 29 papers in 15 countries are listed at

ONO's website. However, it is possible to identify newspapers from other countries with

this position - such as Portugal, Israel, Japan, and Italy - that are not currently ONO

members. ${ }^{24}$ ONO does not secure numbers or names from its past membership and its

website doesn't always carry an updated list of its current membership. ${ }^{25}$

Yet, ONO is the primary source for people conducting studies on news

ombudsmanship. It was certainly the main source of practically all studies conducted in

North America. ONO is also highly regarded among ombudsmen and former incumbents

interviewed for this thesis. It is a place where they can (or could) share experiences and

columns. Table 1 indicates that the number of news ombudsmen worldwide remains

membership in 1992. (Email interview, 10 Oct 2008) Alfred JaCoby, first ONO president, adds: "By late1970s, the newspaper ombudsman concept had solidified to the point that talk began about forming an organization. John Brown, ombudsman at the Edmonton Journal, circulated a series of round-robin letters in the spring of 1979 proposing that the annual conference at the Washington Journalism Center be used as a meeting to establish an organization of newspaper ombudsmen. Brown, as the person who had developed the idea, was offered but declined the initial presidency because the group had a large majority of members from the United States and he was Canadian. Brown became the second president two years later." ("The Newspaper Ombudsman: a Personal Memoir of the Early Days," in www.newsombudsmen.org/jacoby, accessed October 16, 2009.)

${ }^{23}$ These data came from ONO's website in February and March, 2010. From the total number of U.S. members, I subtracted broadcasting ombudsmen and those from other non-newspaper organizations, such as Getty Images, a company that supplies photos to news organizations.

${ }^{24}$ See, for instance: Damas, "Situacion Del Ombudsman en el Mundo"; and Arjen Van Dalen and Mark Deuze, "Readers' Advocates or Newspapers' Ambassadors?" European Journal of Communication, Vol. 21, No. 4, 2006, Pp. 457-475. Besides, Gina Lubrano, former ONO executive secretary, mentioned - at the time of her telephone interview (March 4, 2009) - that there were a couple of American newspapers that didn't hold ONO membership. She mentioned The Miami Herald [which nowadays is a member] and one other newspaper from Texas (she couldn't remember the name) that had a part-time ombudsman. I can also cite the case of the Winnipeg Tribune, which had the post for five years, but didn't hold ONO membership.

${ }^{25}$ This is based on an email interview with Lubrano (10 Oct 2008), and also from the evidence of ONO's website. For instance, the ombudsman of OPovo Journal, in Brazil, listed as Plinio Bortoloni is in fact Paulo Rogerio. Bortoloni finished his mandate in 2007 (In www.newsombudsmen.org/membership/regularmembers, accessed in February and March 2010). However, it is important to highlight ONO's efforts to update and make the site easier to navigate. In February 2010, it launched a new website. The difference from its previous version is significant from my point of view. "Organization of News Ombudsmen launches new website," in www.j-source.ca/english_new/detail.php?id=4775, accessed March 16, 2010.) 
small, though according to Jeffrey Dvorkin, ONO's current executive director, there is growing interest among news media in emerging democracies of the Middle East, Latin America, India, and the former Soviet Republic. ${ }^{26}$

Table 1: News ombudsmen worldwide ${ }^{27}$

\begin{tabular}{|c|c|}
\hline Country & Ombudsmen \\
\hline en & \\
\hline Australia & 2 \\
\hline Brazil & 5 \\
\hline Canada & 3 \\
\hline Colombiat: & 2 \\
\hline Denmark & 3 \\
\hline Estonia & 18 \\
\hline France & 1 \\
\hline Gricat By & 2. \\
\hline India & 1 \\
\hline South $A$ frica & 2 \\
\hline Spain & 1 \\
\hline Sweden & 2. \\
\hline The Netherlands & 3 \\
\hline Prurkey & 2 \\
\hline United States & 22 \\
\hline
\end{tabular}

${ }^{26}$ Jeffrey Dvorkin, telephone interview, 22 Oct 2009.

${ }^{27}$ As listed at ONO's website in February and March 2010. 


\section{The academic research}

In this section I pinpoint what the most cited studies on the newspaper ombudsmanship say, validating - or not - some findings of my research. The vast majority of research on the subject focuses only on U.S. papers. But there are two studies which were conducted with both U.S. and Canadian ombudsmen, ${ }^{28}$ and three others were conducted purely within Canada - two carried interviews with national incumbents and one examined staff who had been exposed to ombudsmen within their papers. ${ }^{29}$

In general, scholars have been positive: the position can be a means of media accountability and/or can enhance a paper's credibility. Yet, this result is usually measured as very modest and some argue that it varies strongly with individual incumbents. ${ }^{30}$ Media scholars have also classified the ombudsmen's role into three major types: complaint manager, in-house critic and public relations practitioner. That last classification has received special attention.

\footnotetext{
${ }^{28}$ James Ettema and Theodore Glasser, "Public Accountability or Public Relations? Newspaper Ombudsmen Define their Role," Journalism Quarterly, Vol. 64, No.1, 1987, Pp. 3-12; and Neil Nemeth, News Ombudsmen in North America: Assessing an Experiment in Social Responsibility, pages 35 to 41. ${ }^{29}$ They are: Keane Shore, Newspaper Ombudsmen in Canada, Master of Journalism Thesis, Carleton University, 1991; Katherine M. Harding, "Death of Newspaper Ombudsmen: Why Canadian Newspapers Have Abandoned their Watchdogs," Master's Research Project, Carleton University, April 2001; and Simon Langlois and Florian Sauvageau, "L'image de L'ombudsman de Presse dans Deux Quotidiens Canadiens," Communication Information, Vol.10, No.2-3, 1989, Pp. 189-210. There are two other studies that do not focus only on U.S. papers: Damas explores ombudsmanship worldwide ("Situacion del Ombudsman en el Mundo"); and Van Dalen and Deuze look specifically at the Netherlands ("Readers' Advocates or Newspapers' Ambassadors?").

${ }^{30}$ See, for instance: Kenneth Starck and Julie Eisele, "Newspaper Ombudsmanship as Viewed by Ombudsmen and their Editors," Newspaper Research Journal, Vol. 20, No. 4, 1999, Pp. 37-48; Andrew Cline, "Ethics and Ethos: Writing an Effective Newspaper Ombudsman Position," Journal of Mass Media Ethics, Vol. 23, No. 2, 2008, Pp. 79-89; and Christopher Meyers, "Creating an Effective Newspaper Ombudsman Position," Journal of Mass Media Ethics, Vol. 15, No. 4, 2000, Pp. 248-256.
} 


\section{The PR thing}

Some scholars conclude that ombudsmen act as public relations practitioners when dealing with the public and offering explanations on why the paper performed an action the way it did. ${ }^{31}$ In fact, five studies point out the public relations role, ${ }^{32}$ of which three cite the PR models included in the book Managing Public Relations. ${ }^{33}$

In their book, Grunig and Hunt argue that public relations is, above all, a "management of communication between an organization and its public," and they identify four models of practice: 1) the press agent/publicity model, which has a propaganda function in which truth is not necessarily important; 2) the publicinformation model, whose purpose is to disseminate truthful information about the organization; 3) the two-way asymmetric model, which is characterized by the use of science and research to persuade the public about the organization's viewpoints in an imbalanced two-way flow of information; and finally 4) the two-way symmetric model, where practitioners serve as mediators, there is dialogue, and the public is as likely to persuade the organization to change its attitudes and behaviours as vice-versa (the main goal is common "understanding between organizations and their publics").

\footnotetext{
${ }^{31}$ In analysing accountability in Canadian media organizations, Peter Desbarats wrote that The Royal Commission on Newspapers acknowledged in its 1981 report that the Toronto Star had done a good thing in implementing an ombudsman, but there was also a payoff for the paper: "The Star wanted to strength its credibility. Thus the move was something of an attempt to attract readers," the report announced. ("Accountability," In Guide to Canadian News Media, Toronto: Harcourt Brace Canada, 1996, page 200.) ${ }^{32}$ They are: Neil Nemeth and Craig Sanders, "Ombudsmen's Interaction with Public Through Columns," Newspaper Research Journal, Vol. 20, No.1, 1999, Pp. 29-42; Lamar W. and Janet A. Bridges, "Newspaper Ombudsman Role during Presidential Campaign," Newspaper Research Journal, Vol. 16, No. 2, 1995, Pp. 76-90; Barbara Hartung et al., "Readers' Perceptions of Purpose of Newspaper Ombudsman Program," Journalism Quarterly, Vol. 65, No.4, 1988, Pp. 914-919; James Bernstein, "The Public's View of Newspaper Accountability," Newspaper Research Journal, Vol. 7, No. 2, 1986, Pp. 1-9; and Ettema and Glasser, "Public Accountability or Public Relations? Newspaper Ombudsmen Define their Role".

${ }^{33}$ James E. Grunig and Todd Hunt, Managing Public Relations, New York: Holt, Rinehart \& Winston, 1984.
} 
Utilizing these categories, Ettema and Glasser evaluated the ombudsmen's job. ${ }^{34}$

They surveyed North American ombudsmen, requesting incumbents to rate the significance of a number of press criticism, feedback and persuasion activities. Among the responses, "give readers a sense that newspaper cares for them" was ranked the most important aspect of the job. ${ }^{35}$

Ettema and Glasser said that ombudsmen serve two masters (the newspaper and the public), but do not acknowledge this divided loyalty, and thus provide ambiguous answers to the question of whether they are public relations people or press critics:

In terms of ombudsmen's description of their role within the news organization, it is clear that public relations activities are strongly and widely endorsed as important to the job. Indeed, it could be argued that ombudsmen's activities are the very model of contemporary public relations practice. Their persuasive function is indicated by the importance attached to giving readers a sense that the newspaper cares about them and by the endorsement of the ideas that readers don't understand the problems journalists face and that the proper response is to educate the public. Ombudsmen's feedback function is indicated by the importance attached to sensitizing reporters, editors and managers to readers' concerns. By comparison, press criticism activities are less strongly and consistently endorsed as important to the job, although these activities do comprise a highly coherent press criticism function. In general, then, at least some public relations activity is nearly universal among ombudsmen, but press criticism activity is not - some ombudsmen clearly hold a much stronger commission to criticize than others. ${ }^{36}$

\footnotetext{
${ }^{34}$ Ettema and Glasser, "Public Accountability or Public Relations? Newspaper Ombudsmen Define their Role." Their study is one of the most cited by media scholars, probably because of the extent and quality of their effort in surveying ombudsmen in North America. Of the 33 known to hold ombudsman roles at the time, only one did not respond to the survey.

${ }^{35}$ In Starck and Eisele's study ("Newspaper Ombudsmanship as Viewed by Ombudsmen and their Editors"), the majority of ombudsmen also reported that they see their most important duty as interacting with readers and providing readers with a voice in the newsroom. Nevertheless, the scholars didn't associate this task with the PR function.

${ }^{36}$ Ettema and Glasser, "Public Accountability or Public Relations? Newspaper Ombudsmen Define their Role," page 11.
} 
In fact, Ettema and Glasser conclude that this dual role can be one of the reasons for the category's "failure" in North America.

Nemeth and Sanders' study discusses ombudsmen's interactions with the public through columns. The columns were examined by analyzing each paragraph and classifying it into one of three forms of behaviour: public relations, accountability or criticism. According to the scholars, more than 80 percent of the paragraphs were related to PR behaviour:
Although ombudsmen primarily practiced the public information model of public relations [which provides a one-way flow of information], most ombudsmen practiced two-way public relations at least half the time, which facilitates a limited public dialogue about the papers' performance. ${ }^{37}$

They add, moreover, that such dialogue might not have occurred otherwise.

Lamar and Janet Bridges studied the ombudsman's role in dealing with reader concerns about fairness and in influencing their newspapers' coverage during a Presidential campaign. ${ }^{38}$ Among their conclusions was that ombudsmen practice the twoway symmetric model of PR because they manage conflict between readers and the newspaper, and improve mutual understanding between both. On the whole, the Bridges affirm that the ombudsman's position helps support the view that a newspaper is a source of credible information while providing self-examination of its performance.

\footnotetext{
${ }^{37}$ Nemeth and Sanders, "Ombudsmen's Interaction with Public through Columns," page 36 . The scholars studied 22 of the 34 U.S. members of ONO in 1994 who wrote columns.

${ }^{38}$ Bridges, "Newspaper Ombudsman Role during Presidential Campaign." Twenty-nine ONO members in the U.S. were sent the questionnaires, but the responses were received from only $58 \%$ of them.
} 
Hartung et al. and Bernstein also mentioned in their findings that ombudsmen may perform public relations activities. To my knowledge, these two studies are the only ones studying ombudsmanship from the readers' perspective. ${ }^{39}$

Hartung et al. tried to analyse the public's perceptions of the ombudsman and the satisfaction with responses among those who had contacted the newspaper. ${ }^{40}$ They found that more than half (57\%) who had called the ombudsman knew him by name (or had referred to him as the ombudsman or readers' representative) and that $61 \%$ of those who called were very satisfied with the paper's response (especially those calling to complain about errors of fact). Hartung et al. affirmed that calling a newspaper ombudsman may have a positive impact on readers and they thus hold up the idea that an ombudsman can be one of the paper's most efficient public relations instruments:

At very least, the ombudsman is an indication of the newspaper's institutional commitment to its readers. At a higher level, the ombudsman is the readers' advocate, a change agent working within the newspaper to make it more competent, more sensitive to its readers' needs and interests, and more socially responsible. ${ }^{41}$

Bernstein's findings also suggest a positive impact among those who contacted an ombudsman. Readers aware of the program tend to perceive greater accountability in the newspaper. ${ }^{42}$ Yet he points out readership of ombudsman's columns has little impact on that view. A newspaper's public editor, Bernstein adds, provides a public relations service to readers by offering one specific means of listening to them.

\footnotetext{
${ }^{39}$ Bernstein, "The Public's View of Newspaper Accountability"; and Hartung et al., "Readers' Perceptions of Purpose of Newspaper Ombudsman Program."

${ }^{40}$ The study was conducted with readers of the San Diego Union, in November 1984. From a list of 438 people who had called the ombudsman that year, 243 were contacted, and 202 were interviewed.

${ }^{41}$ Hartung et al., "Readers' Perceptions of Purpose of Newspaper Ombudsman Program," page 919.

${ }^{42}$ He sent questionnaires to Louisville Times newspapers readers in March, 1981.
} 
Nemeth and Pritchard agree that an ombudsman is an added channel for readers to make their views known, and can provide a useful way for a fast resolution of any problem they may voice. But the PR function that comes implicitly with the job doesn't reduce its value, in their view. As Pritchard puts it:

Ombudsmen who efficiently and effectively resolve the public's complaints also serve the public relations interests of the news organizations that employ them, but the work of ombudsmen is more than mere fluff. They resolve real problems of real people. ${ }^{43}$

\section{The in-house critic and its influence on journalism ethics}

Pritchard researched the impact of a newspaper ombudsman on editors and journalists by comparing professionals from newspapers that had an ombudsman with counterparts from papers that did not. ${ }^{44}$ His study presents two main conclusions. First, journalists working at a newspaper with an ombudsman have a more optimistic perspective of their newspapers' performance (and how their newspapers inform the public) than those at papers without an ombudsman. Second, the presence of an ombudsman does not influence journalists' views on the ethics of controversial newsgathering techniques, such as making use of letters and/or photographs without permission, or using confidential business or government documents.

\footnotetext{
${ }^{43}$ Pritchard, "The Future of Media Accountability," page 189; see also Nemeth, "A News Ombudsman as an Agent of Accountability."

${ }^{44}$ David Pritchard, "The Impact of Newspaper Ombudsmen on Journalists' Attitudes," Journalism Quarterly, Vol. 70, No. 1, 1993, Pp. 77-86. The survey data are from 1983 and come from the book The American Journalist: A Portrait of U.S. News People and their Work, by David H. Weaver and G. Cleveland Wilhoit (Indiana University Press, 1986).
} 
Starck and Eisele conducted a survey evaluating how an ombudsman and editors within the same news organization perceive the role of a public editor. ${ }^{45}$ Almost all the editors and ombudsmen agreed that having the ombudsman position influences their staff in a positive way. In addition, $65 \%$ of the ombudsmen surveyed thought their presence made journalists work more carefully, paying more attention to accuracy and fairness; $53 \%$ of editors were somewhat in agreement.

Langlois and Sauvageau found quite analogous results in their survey of Montreal Gazette and Toronto Star journalists, the only published study conducted solely within Canada. ${ }^{46}$ Half of those journalists said the presence of an ombudsman makes them work more carefully, ${ }^{47}$ and about four-fifths affirmed that the ombudsman was useful to readers. ${ }^{48}$ However, there was one sharp difference between the two papers: $67 \%$ of Star journalists said the ombudsman was useful to them, whereas only $32 \%$ of Gazette journalists asserted that. More than half of Gazette journalists (58\%) thought their colleagues were "not very favourable" to the ombudsman, compared to only $12 \%$ of Star journalists. The scholars speculate that the more favourable response of Star journalists may relate to the fact the position had existed there longer. In their conclusion, Langlois and Sauvageau state that an ombudsman doesn't change the way journalists think about their profession, but can affect the way they work (even among those who had been scrutinized at least once by the ombudsman).

\footnotetext{
${ }^{45}$ Starck and Eisele, "Newspaper Ombudsmanship as Viewed by Ombudsmen and their Editors." Questionnaires were sent to ombudsmen and editors of 32 U.S. papers on the ONO member list in 1999. There were responses from 26 newspapers.

${ }^{46}$ Langlois and Sauvageau, "L'image de L'ombudsman de Presse dans Deux Quotidiens Canadiens." The study was conducted in October 1985 . At the time there were 288 Star journalists and 147 from the Gazette. The percentage response was $50.3 \%$ from the Gazette and $36.8 \%$ from the Star.

${ }^{47}$ Gazette journalists: $52.1 \%$; Star journalists: $57 \%$

${ }^{48}$ Gazette journalists: $70 \%$; Star journalists: $84.3 \%$
} 
There is, of course, a question of whether that impact is positive or not. Neither Langlois and Sauvageau nor Nemeth could say whether impact was seen by respondents as a good thing (working carefully means taking greater pains to avoid errors or to be more through) or a bad thing (working carefully means avoiding writing stories about controversy, that might lead to a complaint). ${ }^{49}$

\section{The ideal ombudsman and peer surveillance}

Scholars have looked at ombudsmanship from various angles. Meyers, for instance, conceives an ideal model of ombudsman. He proposes that public editors ought to have authority within the newsroom "to reward and discipline," and they must be outsiders. Meyers admits potential dangers exist, such as turning an ombudsman into an "ethics cop," and/or producing a climate of "fear and blame" within the newsroom. However, he asserts that his proposal format is a certain path for an effective ombudsman position. $^{50}$

Cline compares the professional attitudes of two American public editors. In his study, the scholar suggests that Daniel Okrent, from the New York Times, was Meyers' ideal model of an ombudsman, while Michael Getler, the Washington Post's public editor at the time of his study, was not. Okrent had true independence as an outsider and stood (in his columns) as if he were a common reader instead of a journalist explaining the culture of a newsroom, writes Cline. ${ }^{51}$

Regardless of how well either performed his job, it is worth noting that Okrent's invitation to be the Times' first public editor came as a way of restoring credibility following the Jayson Blair scandal. That incident, in which a Times journalist invented

\footnotetext{
49 Nemeth, "A News Ombudsman as an Agent of Accountability," page 62.

${ }^{50}$ Meyers, "Creating an Effective Newspaper Ombudsman Position," page 249.

${ }^{51}$ Cline, "Ethics and Ethos: Writing an Effective Newspaper Ombudsman Position."
} 
and plagiarized content in 2002 and 2003, was well documented by the news media at the time. It was agreed that Okrent would have 18 months in that position (the contract would not be renewed), and have total authority to publish two columns per month (or more if he wanted) criticizing the newspaper. Okrent was not on staff, didn't have much experience as a journalist, and assumed the position without a job description. ${ }^{52}$ After finishing his term with the Times, he compiled his columns into a book.

Okrent could not refuse the invitation becauseof its challenges, and yet, he affirms, it would have been simple to say no because there were "easier ways to make friends." ${ }^{, 53}$ His statement highlights that the position, with its role of press criticism, creates conflicts between the ombudsman and journalists/editors in a newsroom. His declaration is a kind of proof of the discomfort produced by the "peer surveillance" exercised by an ombudsman. He is not alone in this affirmation. Some scholars have recognized the additional scrutiny that befalls journalists working at papers with ombudsman; and, as we shall see in chapter 4, my interviewees have indicated that as well. $^{54}$

\section{Everything but ombudsmen}

A couple of scholars have cited arguments (expressed mainly by editors) against ombudsmanship. Two of these arguments seem to be widely held. The first is economic: ombudsmen do not "make" money for newspapers (at least not directly) and cost a lot of

\footnotetext{
52 Neil Hickey, "A Public Editor's Private Story," Columbia Journalism Review, Vol. 44, No.1, 2005, Pp. 2427.

${ }^{53}$ Daniel Okrent, Public Editor \#1: the Collected Columns with Reflections, Reconsiderations, and Even a Few Retractions of the First Ombudsman of the New York Times, New York: Public Affairs, 2006, page 29. ${ }^{54}$ Scholars who mention that include: Pritchard, "The Impact of Newspaper Ombudsmen on Journalists' Attitudes"; Nemeth, News Ombudsmen in North America: Assessing an Experiment in Social Responsibility; and Patrick Lee Plaisance, "The Concept of Media Accountability Reconsidered," Journal of Mass Media Ethics, Vol. 15, No.4, 2000, Pp.257-268.
} 
it, especially for small papers. ${ }^{55}$ Ombudsmen are by and large senior journalists and therefore receive more than the average reporter's salary. The second main argument is that ombudsmen act as a "buffer" between readers and journalists, shielding editors and reporters from complaints. ${ }^{56}$

Shore, for instance, mentions the results of an unpublished survey conducted with 51 major U.S. dailies without ombudsman. The study pointed out that $25 \%$ of editors surveyed cited cost as a reason for not hiring an ombudsman, at the same time that $75 \%$ stated the money for hiring an ombudsman could be better spent in the newsroom operation, and $65 \%$ said the position would create an unnecessary layer between readers and newspapers editors. ${ }^{57}$

In the Canadian context, Shore and Harding conducted interviews with editors of papers without ombudsmen and found similar affirmatives, although their studies were done ten years apart. While Shore is less emphatic about these findings, saying that his thesis "found little evidence of active dislike for the ombudsmen idea," Harding is very convinced of her results: “publishers and editors of major Canadian newspapers who've

\footnotetext{
${ }^{55}$ It must be said, however, that Meyer, citing a 1996 study from Minjeong Kim, affirms that papers with ombudsmen tended to retain their circulation. "The twenty-nine papers with ombudsmen in 1996 had retained, on the average, 89.3 percent of their home county penetration between 1995 and 2000 . The papers of comparable size without ombudsmen retained only 86.3 percent. The difference of 3 percentage point was statistically significant." ("Capacity Measures," pages 171 and 172)

${ }^{56}$ Studies that cite arguments for not employing an ombudsman include: Starck and Eisele, "Newspaper Ombudsmanship as Viewed by Ombudsmen and their Editors," pages 42 and 46; Meyers, "Creating an Effective newspaper Ombudsman Position," page 248; Ettema and Glasser, "Public Accountability or Public Relations?" Newspaper Ombudsmen Define their Role," page 4; Cassandra Tate, "What do ombudsmen do?" Columbia Journalism Review, Vol.23, No. 1, 1984, page 40; and Simon Dumenco, "Is the Newspaper Ombudsman More or Less Obsolete?" Advertising Age, Vol. 79, No.12, 2008, page 18. ${ }^{57}$ Shore, Newspaper Ombudsmen in Canada, page 62. The survey was conducted in 1988 by Kent Lauer, of the Oklahoma State University, for the Organization of News Ombudsmen (ONO). Shore's thesis main focus was on how ombudsmen saw themselves and were perceived by top editors in their papers. He argues ombudsmen are a very good option, if not the best in the case of big papers, for readers to address complaints. He did 35 interviews and analysed the content of numerous columns sent to him by seven ombudsmen.
} 
never hired an ombudsman all cite the same reasons." ${ }^{, 58}$ In fact, Harding's interviewees added a further argument for not having an ombudsman: the perceived lack of independence of an ombudsman from the newsroom. She grouped all three reasons but doesn't suggest an order of importance among them.

But if, in the end, cost and the belief that ombudsmen act as undesirable buffers between journalists and readers were the main reasons editors opposed employing an ombudsman, the reverse question is: why employ one? More specifically, what were the reasons for implementing the position in Canadian papers? Who were responsible? And what do they say about it? That is the topic of the next chapter.

\footnotetext{
${ }^{58}$ Harding, Death of the Newspaper Ombudsman: Why Canadian Newspapers Have Abandoned their Watchdogs?, page 45. Harding suggests in her Master's Research Project that Canadian ombudsmen disappeared because publishers didn't support the idea, and the fact that newsrooms were generally not supportive of the idea. She interviewed 42 people, including professors at journalism schools across Canada, and examined numerous columns from nine ombudsmen.
} 


\section{Chapter 3 \\ NATIONAL CONTEXT}

This chapter explores the reasons for appointing ombudsmen at newspapers

across Canada, and the conditions under which the appointments were made and the incumbents performed their duties.

For the most part, Canadian newspapers announced the implementation of their ombudsmanship on the front page. ${ }^{1}$ Explanations varied in length and detail, but they all stressed that the papers were more approachable than ever before and wanted to become even better. Readers, at least, had not only an established official channel of communication, but also an advocate or a representative to whom they could vent their complaints or concerns. The phrase of the day was to increase the bond between readers and newsroom and the newspaper's credibility. ${ }^{2}$

The first newspaper to implement an ombudsman's office was the Toronto Star.

On May 6, 1972, Mark Harrison became the first Canadian news ombudsman. Three

\footnotetext{
${ }^{1}$ The exceptions were the Toronto Sun ("Meet your new advocate; we've appointed Alison Downie as our first Sun Readership Editor. She's on your side," Toronto Sun, June 5, 2005, p. 2A), and Winnipeg Tribune ("Tribune readers get an ombudsman," Winnipeg Tribune, August 30, 1975, page unknown). All articles from the Winnipeg Tribune were sent to me by email through Lewis St. George Stubbs, research and reference person for the University of Manitoba Archives \& Special Collections. The University of Manitoba is the only Canadian institute to have the paper's "morgue files", dating from the 1930 s to 1980. All other articles and columns sent could be identified by page. (Email interview, 25 Feb; 03 and $17 \mathrm{Mar}$ 2010)

2 "Ombudsman Jack Briglia your advocate at the Free Press starting today!" London Free Press, Jan. 30, 1985, p. 1; "FP selects columnist as first ombudsman," Winnipeg Free Press, Oct. 28, 1987, p. 1; "Journal appoints own ombudsman," Edmonton Journal, Jun. 10, 1978, p. A2; and John Brown, "If we erred, call me," Edmonton Journal, Jun. 30, 1978, p. 1; "Gazette names reader representative," Montreal Gazette, Jun. 5, 1981, p. 1; "Ombudsman named," Calgary Herald, Dec. 7, 1982, p. 1; “Ombudsman appointed," Chronicle Herald, Jan. 16, 1993, p. 1; "Ombudsman's appointment gives readers a voice at the Citizen," Ottawa Citizen, Jan. 24, 1990, p. 1; "The ombudsman - New voice for Star readers," Sudbury Star, Sep. 7, 1990, p. 1; "Editor to represent public in newsroom," Toronto Star, May 6, 1972, p. 1.
} 
years later, in August 1975, the Winnipeg Tribune announced Dick Goodwin as its ombudsman. In June 1978, it was time for the Edmonton Journal to appoint John Brown as ombudsman. In the 1980's, four more newspapers declared the creation of the new job: Montreal Gazette (1981); Calgary Herald (1982); London Free Press (1985); and Winnipeg Free Press (1987). In 1990, the Ottawa Citizen and Sudbury Star announced their ombudsmen in January and September respectively. The most recent newspapers were the Chronicle Herald in 1993 and Toronto Sun in 2005.

Publishers or executive editors of the day named the ombudsmen. They were: Beland Honderich, A. R. Williams, Clark Davey, J. Patrick O’Callaghan, Mark Harrison, Martha Blackburn, Arthur Wood, Graham Dennis, Maurice Switzer and Jim Jennings.

Honderich was the Star's publisher and pioneered the trend in this country. Harrison, who was the Star's first ombudsman, afterwards became executive editor at the Montreal Gazette, and introduced the idea there. Davey was "introduced" to the concept when he became the Gazette's publisher (the ombudsman position had already been there for a couple of years), and then installed the position at the Ottawa Citizen when he became its publisher. And Wood, Williams, Blackburn, Dennis, Switzer and O'Callaghan, respectively publishers of the Winnipeg Free Press, Winnipeg Tribune, London Free Press, Chronicle Herald, Sudbury Star, Edmonton Journal and Calgary Herald $^{3}$ were responsible for the employment of the position in their newspapers. Jim Jennings introduced the position at the Toronto Sun after becoming its editor-in-chief.

\footnotetext{
${ }^{3}$ O'Callaghan implemented the position at two newspapers: the Edmonton Journal and Calgary Herald.
} 
Table 2: Canadian newspaper ombudsmanship

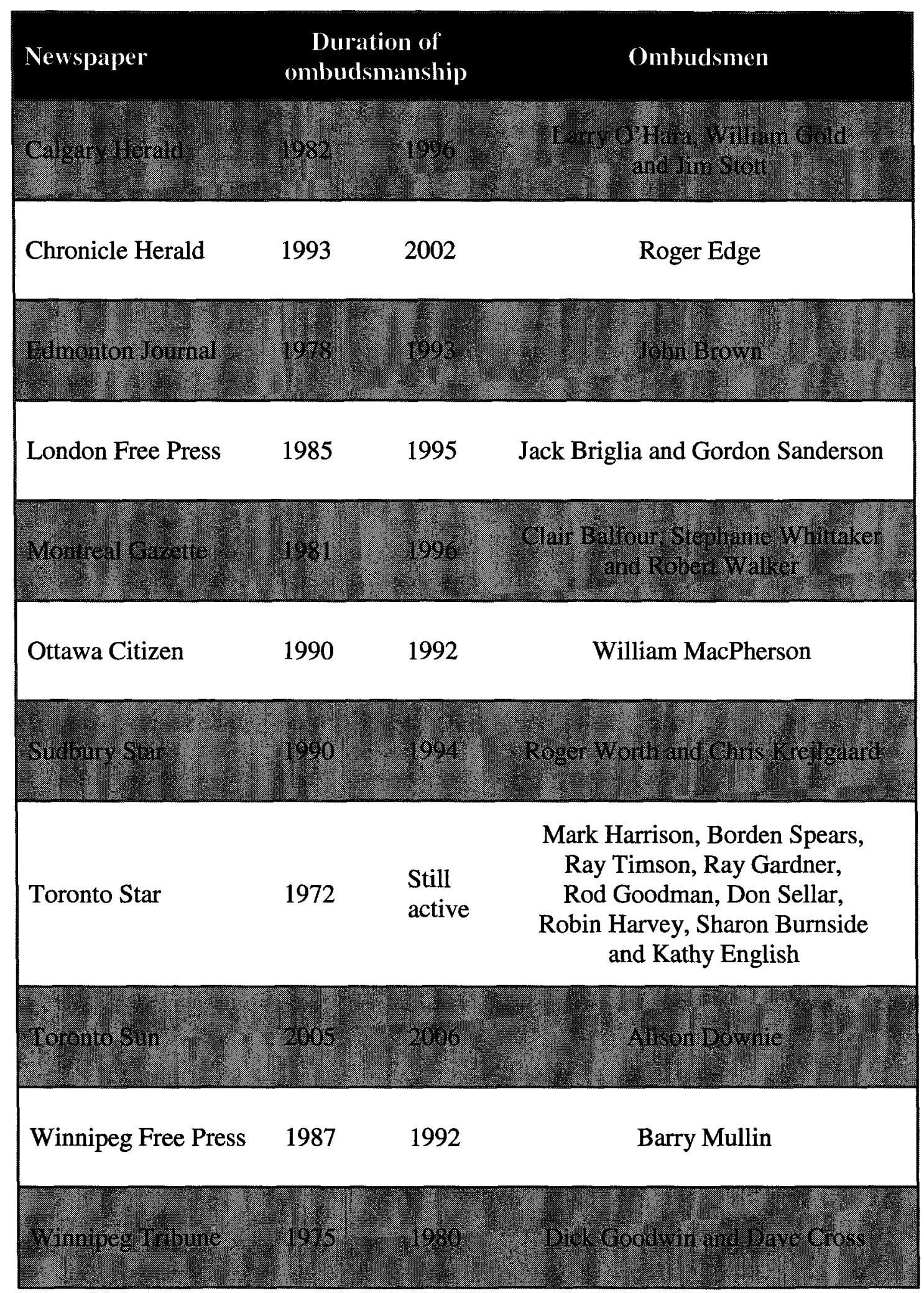




\section{Top executives' motives for ombudsmanship}

What were the top executives' motives for this assignment? As we shall note below, there were a variety of reasons, including official inquiries into the press, awareness of local market monopoly, need for a change in key newsroom positions, the avoidance of bad-tempered readers by publishers, and general public relations use.

It seems that one specific aspect of the Canadian context played a relatively important role, according to Shore and Harding, two Master of Journalism students who independently researched ombudsmanship. ${ }^{4}$ Each referred to two official inquiries into the status and performance of the press, the Special Senate Committee on Mass Media (1970) and the Royal Commission on Newspapers (1981). The inquiries appeared to be important for the Toronto Star, at least. "The Davey Commission may have prompted me to pursue it [ombudsmanship] a little more aggressively," Honderich admitted to Shore. ${ }^{5}$

According to media scholar Dornan, the commissions raised serious concerns, especially around increasing concentration of media ownership, but didn't prompt "much in the way of remedial action." Nevertheless, Dornan acknowledges that they caused a change "in the climate" of the print media. After all, both commissions said state regulation was an option against the diminished open forum and power without accountability that monopoly markets threaten. He points out that Canadian press councils emerged after the commissions' reports.

\footnotetext{
${ }^{4}$ Keane Shore, "Newspaper Ombudsmen in Canada," M.J. Thesis, Carleton University, 1991; and Katherine Harding, "Death of Newspaper Ombudsmen: Why Canadian Newspapers Have Abandoned their Watchdogs," M.J. Research Project, Carleton University, April 2001.

${ }^{5}$ Shore, "Newspaper Ombudsmen in Canada," page 56.

${ }^{6}$ Christopher Dornan, "Free to Be Responsible: The Accountability of the Print Media," In Reporting the Campaign: Electoral Coverage in Canada, Toronto: Dundurn Press Limited, 1991, page 155.
} 
Indeed, John Honderich, Beland Honderich's son, recollects that his father's motives to employ an ombudsman were linked to the implementation of the Ontario Press Council. Beland Honderich was among the journalists and publishers who established the council. "He felt very strongly that something had to be done about accuracy in the media before someone else did," John Honderich says, without mentioning the inquiries directly. $^{7}$

It seems that the elder Honderich's influence went beyond the Star to other papers. Phillip McLeod, London Free Press former editor-in-chief, stresses that Honderich exercised weight over owners and publishers of other daily newspapers in Ontario, ${ }^{8}$ including the ideas of press councils and ombudsmanship. His paper's experiences with its ombudsman may have been discussed at the Council's meetings, McLeod suggests: "He campaigned for that [ombudsmanship]. He made them more aware of his concerns about it [accuracy]. Eventually the owners of the Free Press, including Martha Blackburn, came to agree with him."9

From interviews with former publishers and executive editors at other papers, I have come to believe that the two official inquiries might have played a role in their decisions too, though in a secondary way. As Clark Davey, former publisher at the Ottawa Citizen, puts it:

I'd suspect that the two inquiries you mention may have played a peripheral role in creating fertile spots in my psyche for the need for newspapers to be more accountable to their public and more

\footnotetext{
${ }^{7}$ John Honderich, telephone interview, 17 Jun 2009.

${ }^{8}$ The Star was (and still is) the largest Canadian newspaper.

${ }^{9}$ Phillip McLeod, telephone interview, 15 Sep 2009.
} 
transparent in dealing with reader complaints. But if a factor at all, it would have been only a background one. ${ }^{10}$

However, monopoly was in the minds of executives at three papers. Mark Harrison, the Montreal Gazette's executive editor and before that the first Canadian newspaper ombudsman, was sympathetic about the fact the paper was "alone" in its market: "Because the Gazette is now the only English-language daily newspaper in Montreal, it's especially important that we be receptive to the criticisms and observations of our readers," Harrison wrote in announcing the position. ${ }^{11}$

Harrison reiterated in an interview with Shore that the issue of market monopoly was the main reason for implementation at the Star, too. He said:

A lot depends on the local situation, but the decision to appoint an ombudsman at the Toronto Star arose primarily because the competition had vanished. The Toronto Telegram had just gone out of business. ${ }^{12}$

Philip McLeod, London Free Press former editor-in-chief, says that the Blackburn family (proprietor of the paper) was also conscious of its unusual role of "practically owning all the media" in London. "It was really seen by them as something that they were trying to give back to the community and deal with this awesome power that they [were] perceived to hold," he declares. ${ }^{13}$

It could be that the official commissions had in fact generated awareness that media monopoly markets can reduce the open forum and risk leaving a great power

\footnotetext{
${ }^{10}$ Clark Davey, telephone interview, 06 Jul 2009.

11 "Gazette names reader representative," p. 1. Mark Harrison referred implicitly to the Montreal Star, another English-language Canadian newspaper that folded in 1979.

12 Shore, Newspaper Ombudsmen in Canada, page 55.

${ }^{13}$ McLeod believes that Martha Blackburn, who implemented the position at the London Free Press, didn't have concerns with the official inquiries in general. (Telephone interview, 15 Sep 2009.)
} 
without accountability, as Dornan suggests in his study. Or it could be that the monopoly conditions simply sparked a need to do something that would make them appear approachable to the new audiences to be gained by competitors' closures. If the latter interpretation is correct, then it can be categorized as a sort of PR gesture, which will be soon discussed here as a fifth factor of publishers' and editors' motivation.

Another impetus at some papers was the need for change in some key newsroom positions and the desire of top executives to avoid direct contact with bad-tempered readers. For instance, Kevin Peterson, who was the Calgary Herald's editor-in-chief when the ombudsman was appointed, recalls that J. Patrick O'Callaghan didn't much like dealing with the public. His move to appoint an ombudsman was a selfish one:

He loved being a publisher, but one of the things he didn't like much doing was dealing with complaining readers, which every publisher has to do a very bit of. So he decided to implement the ombudsman's position to create a writer who would listen to those readers and help shepherd their complaints through the newspaper and write a column once a week that would explore some of those issues. In some way you can characterize it as avoidance behaviour on his part. And frankly, Mr. O'Callaghan wanted to make some management changes inside the newsroom and this was a chance to give him [Larry O'Hara] a position of permanence that recognized his experience, but at the same time allowed some management changes inside the newsroom. ${ }^{14}$

The Ottawa Citizen's Clark Davey recalls that when he arrived at the Gazette as publisher, he was not very receptive to the ombudsman idea. He had spent a long time working for other newspapers, including the Globe and Mail, and ombudsmanship didn't seem to him to be a "clever" approach. Davey changed his mind:

I had been used to answering my own phone as publisher of the Vancouver Sun and as managing editor of the Globe. I realized

\footnotetext{
${ }^{14}$ Kevin Peterson, telephone interview, 26 Oct 2009.
} 
very quickly that an ombudsman is a great assistance to the senior management of the paper. He is able to handle a lot of complaints, deal with and write about them intelligently when it is required. Over a period of months, I came to see the benefits of it also as a publisher. ${ }^{15}$

When Davey then went to the Ottawa Citizen as its publisher, he admits that the implementation of the position there was also part of a change in the newsroom that he wanted to put in place. Like O'Callaghan, he achieved two goals in one move:

William MacPherson was a long time friend. He was the editor of the editorial page at the Citizen and I felt there was a time for a change in that position. I thought that his great many years of experience and understanding of the issues that would come up in a newspaper would make him an outstanding ombudsman. I offered him the position and I think he was delighted to accept it. ${ }^{16}$

This fourth impetus - personnel change - also seems to have been a factor at the Chronicle Herald and Edmonton Journal. Roger Edge, the Herald's former ombudsman, remembers that publisher Graham Dennis desired to create that position, but this move allowed him to make other changes in the newsroom as well.

He [Graham Dennis] wanted to create the position. There were some changes coming about that time, so I guess he felt it might be a good time for me to move into another position, so that other people could move up. I accepted it right away. He was always -

${ }^{15}$ Clark Davey, telephone interview, 06 Jul 2009.

${ }^{16}$ Clark Davey, telephone interview, $06 \mathrm{Jul}$ 2009. Here it is worth mentioning that Gordon Fisher, then Citizen editor, explained in an article why the paper needed an ombudsman: "Because you have a hard time getting through our bureaucracy. Because we are busy people, and complaints aren't our favourite things. Because our response is often reflexive, imperious, and wrong. Because dealing with the public is a full-time job. Because sometimes after we stand by our story we end up publishing humiliating corrections, or we end up in court." ("Got a gripe with us? Call your ombudsman," Ottawa Citizen, Mar. 3, 1990, p. B3.) 
and still is - very caring about the newspaper and about the readership. $^{17}$

Linda Hughes, a former Edmonton Journal publisher, was a reporter when the position was introduced at that paper. She states that she doesn't remember much about reasons for adoption, except for changes in the newsroom. "All I remember is that he [John Brown] had been news editor and there was a management shuffle. Somebody else became news editor and he was appointed ombudsman," Hughes states. ${ }^{18} \mathrm{Mr}$. Brown had been news editor for six years prior to being ombudsman.

Jim Jennings, former editor-in-chief of the Toronto Sun, is American. He emphasizes that his work background made him aware of ombudsmen and value their importance. Prior to joining the Sun, he worked for Thomson Newspapers as a vicepresident and editorial director in the United States, and as the group managing editor in London. According to him, Thomson Newspapers had used ombudsmen at some of their properties, such as the Virginian-Pilot, where he was first exposed to the position.

Speaking about the Sun specifically, he says:

The purpose was to provide the reader with an advocate within the newsroom so that readers had the ability to go beyond writing letters to the editor or taking the complaint to the editor-in-chief. It was an advocate they could talk to about any topic. The structure was the readership editor report directly to myself, and she [ombudsman Alison Downie] had the ability to meet with and talk to anyone in the newsroom without prior permission. ${ }^{19}$

\footnotetext{
${ }^{17}$ Roger Edge, telephone interview, 09 Nov 2009. Edge was deputy managing editor before becoming ombudsman. Edge's columns also appeared in the Mail Star, the afternoon edition of the Chronicle Herald.

${ }^{18}$ Linda Hughes, telephone interview, 05 Oct 2009.

${ }^{19} \mathrm{Jim}$ Jennings, telephone interview, $17 \mathrm{Jul} 2009$.
} 
Jennings explains that the job was titled readership editor to keep things simple: "Most readers don't know what an ombudsman is or does."

Alison Downie believes the position also was the result of reader focus groups:

Jim Jennings arranged focus groups shortly after arriving at the Sun and sat through all of them. I attended just a few. I believe Jim felt there should be someone at news meetings and in the newsroom advocating for readers, which would include trying to resolve issues readers might have with the news department and being a point-person for complaints and compliments. ${ }^{20}$

The Sudbury Star was the smallest newspaper to have an ombudsman, and while publisher Maurice Switzer liked the concept, he folded it into the job of editorial page editor. "I understand that the position had usually been established independent - if that's possible - of a newspaper's editorial operations, but for me this gesture towards balanced journalism was better than not addressing the issue at all," he says. ${ }^{21}$ Chris Krejlgaard, second ombudsman, noted: "Basically it was the managing editor at the time [Boris Hrybinsky] who appointed me, but it was part of the editorial writer's position. So if you are the editorial writer, you are also the ombudsman.,22

Switzer says one factor that led to his decision resulted from a public outcry in 1988 over local coverage of the staging of the World Junior Athletic Championships at

\footnotetext{
${ }^{20}$ Alison Downie, telephone interview, 24 Jul 2009; and email interview, 19 Apr 2010. Downie adds that she had personal reasons for accepting the job: "I was offered the readership editor's job a few months after returning to the newsroom following a 14-month battle with breast cancer. I had already stepped down as city editor because the demands of that job were just too stressful considering my health issues. The readership job offered an exciting challenge, as it was a new position that I really believed could be of benefit to readers and newsroom staff, and it also gave me the opportunity to work more regular hours. If I had not been dealing with health issues, the job may not have been as attractive to me. I expect my career likely would have gone in a different direction."

${ }_{21}^{21}$ Maurice Switzer, telephone interview, 19 Oct 2009; and email interview 10 Mar 2009.

${ }^{22}$ Chris Krejlgaard, telephone interview, 28 Oct 2009. I tried for several months to find (Sudbury Star first ombudsman) Roger Worth's contact number or email, but did not. I was told he is still alive, although no one knew his contact information. Worth was the only Canadian former newspaper ombudsman alive (and in condition to talk) that I couldn't reach.
} 
Laurentian University. A story alleged a financial "scandal" over cost over-runs. The problem, Switzer found out, occurred because the Sudbury Star reporter didn't know the difference between "revenue" and "profit." That episode, according to Switzer, was also one factor of many that led him to conclude that the paper needed to be more open about its processes and about admitting when it didn't do a good job on reporting community issues.

My best recollection is that the managing editor of the day, $\mathrm{Al}$ Hogan, was resistant to the idea because he felt it would make his job more difficult in a sometimes highly-charged unionized environment. $^{23}$

Switzer later became the Winnipeg Free Press publisher and had controversial problems with Barry Mullin, its ombudsman, which led to Mullin's resignation. The case will be discussed in chapter $5 .^{24}$

In the Toronto Sun and Sudbury Star's situations, it seems fair to state that an ombudsman meant a straight public relations tool. In both cases, the papers were trying a gesture towards making and/or keeping the audience pleased. As for the London Free Press, Toronto Star and Montreal Gazette, where awareness of market monopoly was directly mentioned by executive editors, the evidence is mixed, although it can still be

\footnotetext{
${ }^{23}$ Maurice Switzer, telephone interview, 19 Oct 2009; and email interview 10 Mar 2009. I tried to contact Al Hogan many times. I sent him emails and also left several messages on his office answering machine through 2009. I received no reply.

${ }^{24}$ I couldn't reach anyone who would talk about the Winnipeg Tribune. Former publishers A. R. Williams and E. H. Wheatley, and former ombudsmen Dick Goodwin and Dave Cross are all dead. I contacted Jim Shilliday, who was a columnist for the paper, but he said that his recollections on the subject were "sketchy" and therefore couldn't help in this matter. I also contacted Vic Grant, who was also a columnist for the paper. In the first attempt, he was on a trip in California and said that he could talk only upon his return in April, 2010. I sent him two follow-up emails, but received no reply. The announcement said the executive editor G. R. Goodwin was being appointed as ombudsman "to give the office the stature [the publisher] wishes it to have" and the position will have "complete independence." ("Tribune readers get an ombudsman," page unknown)
} 
pointed out that an ombudsman in their cases would provide a gesture to help maintain good reader relations.

At the Winnipeg Free Press, it seems various motives came into play, indeed all

five listed in the beginning of this sub-section. This is reflected in the comments of Dave

Lee, former managing editor:

The idea was sort of spreading in those days. Newspapers were flush with cash. He [Arthur Wood] thought it would be a good investment for the newspaper and that readers would feel good about it. He decided that such a position would be beneficial to the newspaper credibility to readers. He asked me for candidates and I recommended Barry Mullin, who was a former city editor but who actually had been demoted to write a general column. ${ }^{25}$ In my view, Mullin was the ideal candidate with an outstanding ability to deal with the public, extensive newsroom background, and a very nice writing style. I have to admit that I was also selfish at the time. It was easier to give up a columnist than giving up one of my reporters or editors. I also remember thinking that it would allow senior editors, like myself, to be able to tell angry callers to call our feedback guy. ${ }^{26}$

In addition, Barry Mullin, the paper's ombudsman, recollects that publisher

Arthur Wood had said the initiative was influenced by a speech he heard and an attempt to resolve some "problems" at his paper:

Art Wood had been in a conference. He had heard how the ombudsman worked and he thought he would try it at the Winnipeg Free Press. ${ }^{27}$ So he appointed me. [At the same time] he needed someone to provide him with a bit of investigation at some of the

\footnotetext{
${ }^{25}$ Mullin was the city editor and Lee was the assistant city editor. When Mullin was removed, Lee replaced him as city editor.

${ }^{26}$ Dave Lee, telephone interview, 29 Oct 2009.

${ }^{27}$ The speech was given by Clair Balfour, the Gazette's first ombudsman, who at the time was also the president of the Organization of News Ombudsmen (ONO). Balfour indeed remembers making many speeches trying to encourage other newspapers to adopt the position as part of his role at ONO. "I don't claim that I caused anybody to do it. I think this kind of thing happens because you say the same thing often enough, or enough people say the same thing, and publishers and editors talk among themselves too," he adds. (Telephone interview, 01 Sep 2009.)
} 
things that were perhaps going wrong [at the paper], and that he needed to have that analysed. ${ }^{28}$

In short, then, stated motivations varied from paper to paper, but seemed to be tied to a few common points: official inquiries into the press, awareness of local market monopoly, need for a change in key newsroom positions, the avoidance of bad tempered readers by publishers, and generally public relations use.

\section{Conditions of employment}

In this section, the terms of employment, such as contract, job description, and time frame for holding the job, will be examined. I have highlighted comments related to the absence of contracts because that may have played a role for some in how they managed their duties. This topic is also important because news ombudsmen elsewhere say firm, written conditions of employment are essential for exercising their duties (see chapter 4).

\section{Contract}

The only Canadian newspaper that gave a contract to its ombudsman was the Ottawa Citizen. ${ }^{29}$ Clark Davey says he wanted to emphasize how independent William

\footnotetext{
${ }^{28}$ Barry Mullin, telephone interview, 17 Oct 2009. Mullin could not recall some specifics at the time of the interview. In a follow-up email (27 Jul 2010), however, he mentions that Wood "had found corrections to misinformation and mistakes in news stories were slow in being printed. Every newspaper has an Our Mistake box somewhere in the paper -- usually page 2. And it was Mr. Wood's opinion that quickly and timely printed Our Mistakes could mitigate possible lawsuits." When interviewed by Harding, Barry Mullin said: "Wood came back from that conference and noticed the paper had a lot of niggling internal difficulties with management. If there was ever any outside criticism they would close ranks, ignore the problem and let the flak fall where it may." ("Death of Newspaper Ombudsmen: Why Canadian Newspapers Have Abandoned their Watchdogs," page 17.)

${ }^{29}$ Although Shore writes that Gordon Sanderson had a two-year contract with the paper (Newspaper Ombudsmen in Canada, page 50), in my interview the former ombudsman said that he worked on an
} 
MacPherson could be in his role. ${ }^{30}$ The official arrangement was explicitly publicized at the time of appointment by then editor Gordon Fisher:

Many of us have known for some time that newspaper readers needed a representative of their own, and we are indebted to publisher Clark Davey for appointing one. Anxieties aside, we are pleased that he has done so under terms that allows MacPherson to write as he wishes with absolutely no interference.

For the record, MacPherson is 62 years old, and will retire in three years. He has a contract with the publisher allowing him complete independence from the editor. His column, which will run every Saturday, will be subject to review by the publisher only. There are, however, safeguards within that contract guaranteeing the ombudsman financial security if he feels his independence has been impinged in any manner.

If MacPherson feels he's been gagged, he can walk away with financial security. It's a no-cut contract. ${ }^{31}$

Nevertheless, the majority of former ombudsmen interviewed say that a contract would not have made a difference. Edge, Sellar, Goodman, Downie, Balfour and Whittaker all say that even if the publisher didn't agree with every finding and had discussions with them about a column or two, they had a sense of independence. They say their columns were not censored and they had the power to talk to anyone on staff. As Stephanie Whittaker explains:

My editor [Mark Harrison] said to me, "We want you to be as autonomous as you can possibly be." It seems difficult to employ someone to criticize your organization. But it works and it can be

\footnotetext{
"agreement", and not on a fixed-time contract. (Telephone Interview, 30 Sep 2009) Besides, in his appointment, there was no mention about a contract; and Phillip McLeod, former editor-in-chief, could not remember about that specifically.

${ }^{30}$ Clark Davey, telephone interview, 06 Jul 2009.

${ }^{31}$ Fisher, "Got a gripe with us? Call your ombudsman," p. B3. Actually there were two announcements. The first was on January 24, 1990 ("Ombudsman's appointment gives readers a voice at the Citizen," Ottawa Citizen, p. 1). It said MacPherson would start as ombudsman in March. And in March, Fisher reaffirmed the appointment, giving more details on how the ombudsman would operate and the reasons for that.
} 
done. If this person knows that he/she has full latitude to criticize the organization, then it works just fine. ${ }^{32}$

As an example, Whittaker talked about a column she wrote that directly criticized her editor. It was related to Garry Trudeau's cartoons about AIDS. The cartoons were highly satirical and editor Harrison thought they were offensive to readers, refusing to published them. The reaction from Gazette readers was enormous and mixed. Whittaker tackled the controversy, saying her editor should not have removed the cartoons. "It took me lot of courage. He sent me a congratulatory memo saying, 'You really stood up to me and I congratulate you.' It was an emotional moment for me," she emphasises.

Clair Balfour, who worked with the same editor, also says lacking a contract didn't bother him, but he came to believe that it would be a good option:

Over time, as I learned about the job myself and as I talked with more people, I think other ombudsmen and I felt that a contract was probably a good idea. I don't recall encountering that problem [of censorship]. The senior people at the Gazette were in those days experienced and sensible, but in talking with other ombudsmen over the years, sharing information and so on, I think a contract is a good proposal. It is probably better if the reporting relationship is with the publisher, not with the editor, because it is possible to have a conflict of interest with the editor. An ombudsman could be critical of some aspect of the operation of the newsroom for which the editor is responsible. Most editors are big enough people to take the criticism, but it is perhaps easier for everybody if the ombudsman can criticize the whole news operation including the editor's role. It is not perfect if we report to the publisher, but it is probably a little bit better. ${ }^{34}$

\footnotetext{
${ }^{32}$ Stephanie Whittaker, telephone interview, 16 Jul 2009.

${ }^{33}$ Stephanie Whittaker, "The Gazette erred in not running Doonesbury strips," Montreal Gazette, Apr. 10, 1989, p. B3.

${ }^{34}$ Clair Balfour, telephone interview, 01 Sep 2009.
} 
The Gazette was the only Canadian paper to have its ombudsmen reporting to the editor. $^{35}$

Three former ombudsmen - Mullin, Burnside, and Harvey - are emphatic that a written contract is preferable. Coincidence or not, they seem to be the only Canadian incumbents interviewed who had problems interfacing with their publishers, as we shall see in chapter 5 .

Barry Mullin, who resigned as Winnipeg Free Press ombudsman after a change in job conditions, thinks that "definitely" a contract would make a difference. "Contracts seem to be harder to break and there is a cut and dry method: if a contract is broken, the individual is paid out," he says. ${ }^{36}$

Sharon Burnside, who felt less comfortable in working with her second publisher, Jagoda Pike, says that "anything" that guarantees the independence of the position is good. Yet she also affirms that a shield contract wouldn't make much difference in how she proceeded in her job:

The person doing that job has to know that her/his job is not in jeopardy if they choose to write something that is critical of the paper. The credibility of the position is the only thing that really matters. The newsroom has to have confidence that you are being fair. Readers have to have confidence that you are being fair. ${ }^{37}$

\footnotetext{
${ }^{35}$ Although lan Urquhart, Toronto Star editorial page editor and a long time employee of the paper, says there was a time when the ombudsman reported to the editor-in-chief of the Star, I couldn't confirm that. There were three occasions on which Star ombudsmen were announced by the editors-in-chief, although it wasn't said that the ombudsmen would report to them. For details see: "Borden Spears named 'Man at the Star', Reynolds city editor," Toronto Star, Jan. 21, 1974, p. A3 (when Borden Spears was announced by Martin Goodman); "Ray Timson takes charge of Star's accuracy bureau," Toronto Star, Aug. 30, 1980, p. A2 (when Ray Timson was announced by Denis Harvey); and "Veteran editor Ray Gardner appointed Star ombudsman," Toronto Star, Feb. 13, 1982, p. A3 (when Ray Gardner was appointed by George Radwanski). Other former Star ombudsmen - Rod Goodman, Don Sellar, Sharon Burnside, Robin Harvey, and Kathy English - reported to the publisher.

${ }^{36}$ Barry Mullin, telephone interview, 17 Oct 2009.

${ }^{37}$ Sharon Burnside, telephone interview, 25 June 2009.
} 
And Robin Harvey, who had some conflicts with publisher John Honderich and managing editor Mary Deanne Shears, affirms that a contract would be "really" important. "That would resolve a lot of problems with the position at the Star. And I also think that no one should be ombudsman forever. I think four or five years is enough. Papers evolve. Points of view evolve."38

\section{Unlimited time frame}

The Toronto Star doesn't have a time limit for serving in the position; neither did any other Canadian paper. Ombudsmen could hold their position for as long as they wanted, and they often held it for many years. Don Sellar's lengthy tenure is a good example of how long an ombudsman can be in the post. Sellar held the job for eight years, left the paper for a sabbatical year, and returned for just over three years before taking a buyout. "I thought eight years was plenty. That it was time for someone else to do it. They invited me to come back, so I did that. I guess I could still be there today [if he hadn't taken the buyout]., 39

Other ombudsmen, including those who held the job for just one, two or three years, could have stayed on for as long as they wanted. Most retired from work or asked to leave the post. There were five exceptions. In the case of Alison Downie (Toronto Sun), Gordon Sanderson (London Free Press) and Chris Krejlgaard (Sudbury Star), the papers abolished the position. Sharon Burnside (Toronto Star) was asked to return to her previous function at the paper. And Dave Cross (Winnipeg Tribune) lost his post when the paper folded less than two years after he was appointed.

Table 3 lists the ombudsmen who held the job for at least four years.

\footnotetext{
${ }^{38}$ Robin Harvey, in person interview, 15 Oct 2009.

${ }^{39}$ Don Sellar, telephone interview, 22 Jun 2009.
} 
Table 3: Ombudsmen who held the job over four years

\begin{tabular}{|c|c|}
\hline Ombudsman & Years spent in the job \\
\hline Borden Spears & $61 / 2$ \\
\hline Don Sellar & 11 \\
\hline Jack Briglia & 6 \\
\hline John Brown & 15 \\
\hline Rod Goodman & 8 \\
\hline
\end{tabular}

\section{$\underline{\text { Job description }}$}

Canadian ombudsmen had to write their own job description and come up with a day-to-day recipe on how to deal with their tasks. ${ }^{40}$ Mark Harrison, former Star ombudsman, told Harding he was not given any detail on how to set up the role. ${ }^{41}$ Others faced a similar reality. Roger Edge, former Halifax Chronicle Herald ombudsman, didn't

\footnotetext{
${ }^{40}$ Alfred JaCoby, first ONO president and former reader's representative of the San Diego Union, also says this when writing his recollections of the position's early days in the United States. ("The Newspaper Ombudsman: a Personal Memoir of the Early Days," in www.newsombudsmen.org/jacoby, accessed October 16, 2009.)

${ }^{41}$ In an interview with Harding, Harrison affirmed: "Honderich wanted an ombudsman, but didn't set in any detail what he wanted. He left it to me to create the role. And that's the way it began." "Death of Newspaper Ombudsmen: Why Canadian Newspapers Have Abandoned their Watchdogs," page 19.)
} 
receive a job description and had to do a little research on his own: "I was familiar with the position and the term. There had been ombudsmen in government for quite a while, so I knew roughly what was expected. Of course, once I was appointed I did a little bit of study on it." ${ }^{42}$

The same occurred with Barry Mullin, former Winnipeg Free Press ombudsman:

When you take on a new job, you try to find out from people who have done the job what it entails. So I contacted Clair Belfour [then Gazette ombudsman] and I found out that there was an organization of newspaper ombudsmen [ONO] and then I made a couple of telephone calls. I think one of the first fellows I talked to was Art Nauman at the Sacramento Bee and he provided me with good insight what the job entailed. ${ }^{43}$

Even Don Sellar, the sixth ombudsman at Toronto Star, inherited no formal job description:

When I began as ombud, my predecessor, Rod Goodman, gave me the original of a document signed by Chris Davies, who had been in charge of industrial relations at the paper. The one-page document made it clear the job was a management position to be filled by management. When I decided to take the buyout in 2004, I wrote the first draft of the job description. Made it quite informal. A guy from human resources [Brian Daly (now vice-president, human resources)] made a few changes and posted it. ${ }^{44}$

\footnotetext{
${ }^{42}$ Roger Edge, telephone interview, 09 Nov 2009.

${ }^{43}$ Barry Mullin, telephone interview, 17 Oct 2009.

${ }^{44}$ Don Sellar, telephone interview, 22 Jun 2009; and email interview, 9 Mar and 13 Apr 2010. While conducting interviews at Toronto Star, I had access to a document entitled "Position Vacancy" dated January 15, 2007. It stated: "Reporting to the Publisher, the Ombud serves as a meeting point between the Toronto Star and its readers. Duties include handling public complaints and concerns about news and feature content in the Star, managing the Bureau of Accuracy, shepherding Ontario Press Council cases, writing a weekly column critiquing the paper's journalism, and broadly demonstrating the Star's credibility, openness and accountability."
} 
It seems that only the Sudbury Star prepared a document for an ombudsman, in this case for its second incumbent. ${ }^{45}$ "Basically there was a job description for editorial page editor and that was also act as the ombudsman," recalls Chris Krejlgaard. ${ }^{46}$

This lack of a formal outline of what the work involves appears to have played no major problems for Canadian ombudsmen, except one: Barry Mullin from the Winnipeg Free Press. As we shall see in detail in chapter 5, Mullin continued to perform his duties when publishers changed at his paper, but he found himself in difficulty when the new publisher, Maurice Switzer, thought the job should not include writing columns critical of newspaper actions.

It is also a fact that the papers and/or many ombudsmen (especially in their first columns) explained what the job entailed, and what they could do for readers. Maybe these explanations served not only as a job description but also as an informal - though highly public - contract. Their duties were clearly outlined and are the subject of the next chapter. $^{47}$

\footnotetext{
${ }^{45}$ It was not possible to confirm that information for the Edmonton Journal or Calgary Herald, and my interviewees couldn't remember. From the articles analysed of the Winnipeg Tribune, I could not infer existence or not of a formal job description.

${ }^{46}$ Chris Krejlgaard, telephone interview, 28 Oct 2009.

${ }^{47}$ See, for instance, the columns: Jack Briglia, "Openness and credibility ombudsman's basic concern," London Free Press, Jan. 30, 1985, p. A13; Sharon Burnside, "Let me get this right, I'm here to serve," Toronto Star, Mar. 12, 2005, p. F06; Alison Downie, "Meet your new advocate; we've appointed Alison Downie as our first Sun Readership Editor. She's on your side," p. 2A; Kathy English, "Our commitment to credibility," Toronto Star, Jun. 16, 2007, p. A6; Larry O'Hara, "A new way for the readers to talk to The Herald," Calgary Herald, Dec. 7, 1982, p. A8; Gordon Sanderson, "Reader's advocate hopes to achieve fair balance," London Free Press, Feb. 16, 1991, p. A2; Stephanie Whittaker, "Here's what newspaper's ombudsman aims to do," Montreal Gazette, Apr. 3, 1989, p. B3; and Roger Worth, "The ombudsman: a spokesman for Star readers," Sudbury Star, Sep. 7, 1990, p. A5.
} 


\section{Chapter 4 \\ WHO OMBUDSMEN ARE AND WHAT THEY DO}

This chapter examines who Canadian newspaper ombudsmen are and what they do. It explores the columns they wrote as part of their duties, describing selected patterns and their typical stance on selected issues. Columns, as we shall see later, serve as the principal enforcement aspect of ombudsman accountability. In addition, this chapter also presents my interviewees' views on the effectiveness of the position as a whole.

\section{Who are they?}

In this section I compare some demographic data of Canadian ombudsmanship ombudsmen's age, salary, gender and length of employment, as well as circulation figures - with of those highlighted in three important U.S. studies. These statistics are useful in providing a general sense of the Canadian ombudsmen's profile, and most importantly, reinforcing some characteristics of the ombudsmanship model exercised in this country. These data combined with the employment conditions presented in chapter 3 will be discussed as a weakness of this form of media accountability in the concluding chapter.

In 1982, Mogavero reported that the typical ombudsman was a male journalist, aged 53, who had been working more than 20 years at the newspaper that appointed him. ${ }^{1}$ In 1985, Ettema and Glasser obtained comparable results. They stated that North American ombudsmen had an average age of 55.4, with 20 years of editing experience

\footnotetext{
${ }^{1}$ Donald T. Mogavero, "The American Press Ombudsman," Journalism Quarterly, Vol. 59. No. 4, 1982, Pp. 548-580. He interviewed 18 of the 22 US newspaper ombudsmen that were part of ONO's members list.
} 
plus 10 years of reporting experience. They also mentioned that ombudsmen were well paid, earning at the time between $\$ 40,000$ and $\$ 50,000$, and worked for larger papers (only four had a circulation of 100,000 or less). ${ }^{2}$

In 1999, Nemeth repeated Ettema and Glasser's survey; he had 23 respondents. ${ }^{3}$ The average age was similar, $53,{ }^{4}$ but ombudsmen had somewhat less professional experience than in the previous study, although still substantial. He also noted that at this time 40 per cent were women, three were African American, and three were Latin American. ${ }^{5}$ And 19 of the 23 worked at newspapers with circulation of more than 200,000 .

In Canada, the portrait of an ombudsman as a senior journalist - around his/her $50 \mathrm{~s}$, and with exceptional years of professional experience - is by and large accurate. Canadian ombudsmen have been mainly male journalists with at least 20 years of experience. Of the 27 newspaper ombudsmen Canada has had so far, only five have been women: Whittaker (Gazette), Downie (Toronto Sun), Harvey, Burnside, and English (all Toronto Star). Only three were not long-time employees at the papers prior to appointment: Downie had two years at the Toronto Sun, Krejlgaard had two months at

\footnotetext{
2 James Ettema and Theodore Glasser's study was conducted in 1985, but published in 1987. Of the 32 ombudsmen interviewed, there were 29 U.S. and 4 Canadians; 6 earned less than $\$ 40,000$, 11 earned more than $\$ 50,000$, and 12 earned between those figures. ("Public Accountability or Public Relations? Newspaper Ombudsmen Define Their Role," Journalism Quarterly, Vol. 64, No.1, 1987, pages 6 and 7.) ${ }^{3}$ The study involved Canadian respondents too, but the author doesn't say how many; a U.S. attorney and a full-time academic were also among people surveyed. The sample drew from ONO's 36 regular members at the time. (Neil Nemeth, News Ombudsmen in North America: Assessing an Experiment in Social Responsibility, Praeger: Westport, Conn, 2003, pages 35 to 42.)

${ }^{4}$ The age profile is still found at present. Jeffrey Dvorkin, former ombudsman at National Public Radio in the United States and ONO executive director, wrote an article in 2005 stating that ombudsmen are usually at mid- or late career. ("News Ombudsmen and Stress," Dart Center for Journalism \&Trauma, In dartcenter.org/content/news-ombudsmen-and-stress, accessed October 21, 2009.)

${ }^{5}$ Race was not included in the 1999 survey.
} 
the Sudbury Star, and English worked as a reporter at the Star in the 1980s and returned as its public editor in 2007.

Canadian ombudsmanship has had three exceptionally young ombudsmen. John Brown and Clair Balfour were appointed at the age of 39; and Stephanie Whitaker, who was the first Canadian female ombudsman, was also the youngest, when she assumed the post at the age of $34 .^{6}$ Among those for whom data are available, the average age of Canadian ombudsmen is $47.8,{ }^{7}$ a little lower than in the United States. However, the data are not strictly comparable: U.S. data represent age at the time of the surveys, while my data are based on time of appointment.

Salaries seem to have been fairly high. Although the majority of interviewees did not want to provide their salaries at the time they were ombudsmen, they affirmed that it was at a senior level. I could obtain some information from three former ombudsmen: Stephanie Whitaker of the Montreal Gazette states her annual salary was around $\$ 65,000$ back in 1989; Sharon Burnside, former ombudsman at the Toronto Star, declares that hers was around $\$ 100,000$ in 2005; and Gordon Sanderson, who was second ombudsman at the London Free Press on a part-time basis, ${ }^{8}$ said his weekly payment was around $\$ 1,000$, which leads to an annual salary close to $\$ 52,000$ back in $1991 .^{9}$

\footnotetext{
'Whittaker states that in 1989, when she attended ONO's annual conference in California, demographics were much the same - "old" newsmen (around their 50s and 60s) who had been managing editors or editors. "There was no other woman there," she says. (Telephone interview, 16 Jul 2009) On the other hand, Julie Miville-Dechêne, Radio-Canada ombudsman, says that at her first ONO conference, in 2007, there were both younger people and other women. (Telephone interview, 29 Oct 2009)

${ }^{7}$ This datum comes from the average of 11 ombudsmen whose age was known at the time of appointment: Stephanie Whittaker, 34; John Brown, 39; Clair Balfour, 39; Robin Harvey, 43; Barry Mullin, 46; Don Sellar, 46; Mark Harrison, 47; Kathy English, 49; Ray Timson, 52; William MacPherson, 62; and Borden Spears, 69.

${ }^{8}$ Sanderson had already retired from the London Free Press when he accepted the part-time job.

${ }^{9}$ As a measure of comparison, Jim Stott, Calgary Herald's last ombudsman, stated in a column that according to Statistics Canada there were 41,550 full-time journalists in Canada in 1991, with an average income of $\$ 37,918$. ("Just in case you wondered, a journalist is..." Calgary Herald, Jun. 20, 1993, p. A7)
} 
And at the time of their first ombudsman's appointment, Canadian papers all had circulation above 100,000, with the exception of the Sudbury Star and Winnipeg Tribune with average figures respectively of 29,483 and $75,000 .^{10}$

Table 4: Canadian papers' circulation at the time they introduced an ombudsman ${ }^{11}$

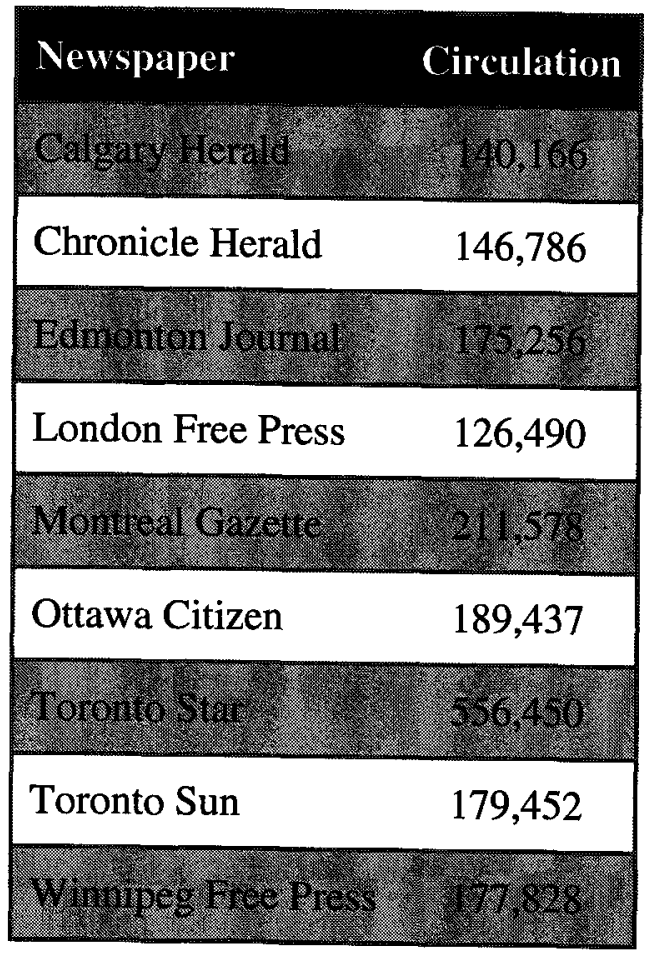

\footnotetext{
${ }^{10}$ According to Lewis St. George Stubbs, a librarian at the Winnipeg University Library and Archives, the Winnipeg Tribune on September 6, 1975 (time of the implementation of the ombudsman's position at the paper) changed its format making it larger, including more classifieds. Circulation increased by 30,000 from the previous 75,000 subscribers "in a matter of months." (Email interview, 17 Mar 2010.) In fact, according to the Canadian Advertising Rates and Data statement ending June, 1978, three years after the ombudsman's implementation, the Winnipeg Tribune had an average total paid circulation of 106,795. ${ }^{11}$ The statistics are from Canadian Advertising Rates and Data. I tried to get the information from issues close of the implementation of the position at each newspaper. See bibliography for details. The exception was the data for the Toronto Star, which I took from the Star's first page at the time of the implementation (Carleton Library doesn't hold Canadian Advertising Rates and Data back to 1972).
} 


\section{The tasks}

Ombudsmanship has been adapted according to newsroom culture and structure, and the activities and autonomy of the position vary to some extent among news organizations. However, in general, an ombudsman's main task is to listen to readers' (or sources') complaints, pass them along to reporters and editors in person or by memo, ${ }^{12}$ get the paper's side of the story, respond to the complainant (individually or by discussing the matter in a published column $)^{13}$ and, if needed, demand or write a published correction or clarification. Grievances range from grammatical errors to news judgment to libel. In dealing with readers, ombudsmen are supposed to explain how and/or why the newspaper did what it did, shedding light on newsgathering practices and journalistic "rituals" unfamiliar to many members of the public.

Alison Downie's narrative of her days in the position gives a typical picture of what other ombudsmen and former ombudsmen experienced:

The good bulk of my day was communicating with readers by phone calls, emails, and written letters. I addressed issues from factual errors in the paper to the content - what we were covering or what we weren't. Assuming that the complaint was about a factual error, I would go to the writer and if the writer had agreed that there was an error, then they would run a correction in the newspaper. If the writer stood by his/her information, then I would do my own investigation. If they were wrong, I would then speak with the editor, but I would go to the source first, the writer first. And if I still felt that we were not resolving [the problem], then I would go to Jim [Jennings, then Sun's editor-in-chief], as the boss of all the editors. And the feedback I would receive from readers, I would then give to our editors. For example, over the course of a week, everything I would receive from sports I would give to the

\footnotetext{
${ }^{12}$ In describing their duties, former ombudsmen say they wrote memos. The exception seems to have occurred at the Sudbury Star, where Chris Krejlgaard, second ombudsman, doesn't recall writing memos, only verbally talking with reporters and/or editors. (Telephone interview, 28 Oct 2009.)

${ }^{13}$ Many scholars, such as Mogavero ("The American Press Ombudsman"), and Ettema and Glasser ("Public Accountability or Public Relations? Newspaper Ombudsmen Define Their Role") have stated that a minority of ombudsmen did not write columns.
} 
sports editor [via internal memo]. And then once a week I would decide what I wanted to write about [for my column]. Sometimes I would write pieces of different things, and sometimes a whole column [would be about] one thing. ${ }^{14}$

That this is widespread practice is reflected in the similarity with this 1989 column by Stephanie Whittaker, explaining what her role was and how she would proceed after receiving a complaint:

By telephone, mail and fax [I field readers' complaints]. I route your complaints to the appropriate newsroom employees for their comments. If a story is factually erroneous, a correction is published. Stories that contain misleading information are rectified by published clarifications.

It is often said that the only thing newspapers have is their credibility. When credibility is tarnished by errors, a mea culpa is essential.

I also act as a conduit for readers who simply want editors and reporters to hear their comments and observations about the paper.

Readers question various aspects of The Gazette's editorial content: whether all facets of a story have been adequately covered, the news judgments of editors who determine what goes on the front page, why the newspaper fails to cover some events, whether news stories and photographs invade citizens' privacy.

If I believe readers' criticism is deserved, I'll say so in my weekly column, published Mondays on this page, B-3. If the criticism is unwarranted and based on a misunderstanding of what newspapers do, I'll explain to readers how things work..$^{15}$

There are cases where ombudsmen have dealt with libel cases (usually with the help of a lawyer) and with problems in online content. Sometimes they wrote the corrections that appeared in print or were involved in press council complaints, as did, for instance, Gordon Sanderson, London Free Press second ombudsman, and the Toronto

\footnotetext{
${ }^{14}$ Alison Downie, telephone interview, 24 Jul 2009.

${ }^{15}$ Stephanie Whittaker, "Here's what newspaper's ombudsman aims to do," Montreal Gazette, Apr. 3, 1989, p. B3.
} 
Star's ombudsmen. ${ }^{16}$ From time to time, they also gave speeches to schools and community groups about journalism in general or their particular role.

Ombudsmen at the Toronto Star deal with all the above; their duties have expanded over time. Don Sellar, for instance, says that when he started the job he had no responsibility for libel cases. It was the newsroom that did the investigation required. That changed when one particularly difficult libel case cost the paper a lot of money:

From that day forward I was in charge of receiving libel claims. It was a way of making sure that when a libel claim comes in, it was looked at carefully. And you have three days to publish a correction - Saturdays and Sundays count. That was part of the ombud job and it is still. ${ }^{17}$

The job seems busier at the Star than it ever was at other Canadian papers. Kathy English, the paper's public editor, counts on the help of an assistant. ${ }^{18} \mathrm{Liz}$ McDonnell, who has been English's associate since May 2009, helps in investigating fact complaints, answering readers' phone calls, and sometimes writing draft corrections for publication. "[If I were not here,] she would be working 24 hours a day. I don't think her job and what needs to be done would be possible without this [associate] position. But I do the light work. Kathy is the one who gets the hard work," McDonnell says. ${ }^{19}$

\footnotetext{
${ }^{16}$ In general, Star ombudsmen haven't liked dealing with press council complaints. They tend to see this as an "odd" position to be in, because it is work devoted entirely to defending the paper. From Rod Goodman, Don Sellar, Robin Harvey, Sharon Burnside and Kathy English interviews.

${ }^{17}$ Don Sellar, telephone interview, 22 Jun 2009.

${ }^{18}$ According to Kathy English, there are on average a dozen complaints from the Ontario Press Council a year; 30 libel notices per year; 400 hundred emails a month; and a minimum of six phone calls a day. (In person interview, 15 and 16 Jun 2009.)

${ }^{19}$ Liz MCDonnell, in person interview, 15 Jun 2009. McDonnell has worked for the company for 13 years in a variety of departments, including circulation, sales and advertising. She has an undergraduate degree in drama and is finishing a master's degree in Cultural Studies.
} 
Other Star ombudsmen acknowledge the support that an assistant brings to the job. ${ }^{20}$ In fact, the assistant's role has grown over the years, as reflected by a change in title from "ombudsman's assistant" to "public editor's associate." The alteration occurred during the tenure of Sharon Burnside, who says the name change helped establish the new role at the office and at the paper. ${ }^{21}$

Regardless of secretarial help, it seems fair to state that ombudsmen were busy people. Certainly my interviewees generally said that. ${ }^{22}$ They also affirmed that the volume of complaints would vary according to the problems of the day. Pictures of dead people, ${ }^{23}$ or stories reporting about the Middle East, for example, would always increase the quantity of phone calls, letters, fax, or emails (the later ombudsmen, not surprisingly, tended to receive more emails than letters).

In his first column, Mark Harrison stated that in the three weeks since the announcement of his appointment, which encouraged readers to write to him, he had

\footnotetext{
${ }^{20}$ Montreal Gazette and Calgary Herald ombudsmen had assistants as well, but their role seemed to have been simpler than as it has been at the Star, as implied in Stephanie Whitaker and Clair Balfour's interviews (dated respectively July 16 and September 01, 2009), and in Jim Stott's farewell column ("After 30,000 calls and 400 columns - that's a wrap: Veteran journalist bids adieu after 10 years as ombudsman," Calgary Herald, Jan 28, 1996, p. A7).

${ }^{21}$ Sharon Burnside, telephone interview, 25 Jun 2009. It may be worth noting the role's expansion was also noticed by Joan Vander Doelen, who worked for four ombudsmen at the paper: Harvey, Sellar, Burnside and English. "I was reading and replying to emails and I was becoming very significant at the role. The volume [of electronic complaints] had increased. If I noticed that the complaint [a small one] was accurate, I would forward the email to the reporter or to the editor and start the process from there," Doelen says about the tasks at her latest time as an associate. She is now working as assistant to publisher John Cruickshank. (In person interview, 15 Jun 2009.)

${ }^{22} \mathrm{My}$ interviewees used to keep track of complaints, but the majority couldn't remember an average number after so many years away from the job.

${ }^{23}$ Overall, ombudsmen emphasized in interviews and in columns that pictures involving death, accidents or funerals raised the average number of readers' complaints. Robert Walker, for instance, wrote about the voluminous number of complaints received because of a front-page picture of baseball player John McSherry suffering a heart attack at Riverfront Stadium. About 250 telephone calls from readers who objected to the picture was "the second-largest number of complaints on a single issue in the roughly six years that I have been the ombudsman. (We received about 500 calls and letters about a front-page photograph in 1989 of one of the victims of a mass killing at the Ecole Polytechnique of the Universite de Montreal.)" ("McGill ethics students hated picture of dying umpire," Montreal Gazette, Apr. 15, 1996, p. B3.)
} 
received "more than 600 letters and about 300 phone calls." ${ }^{24}$ John Brown also stated that his first week at his new office at the Edmonton Journal was busy, with an average of 20 calls a day. ${ }^{25}$ Alison Downie, from the Toronto Sun, wrote that her first week as readership editor had been an "eye-opener" and demanding: "Since the [the inaugural] column appeared, I have talked to dozens of readers on the telephone and made my way through more than 100 emails."26

In their respective farewell columns, Dick Goodwin said he received a daily average of 20 phone calls and several letters; Jack Briglia stated that during his last year he had spoken to and received letters from 1,340 people, with close to 7,000 over his sixyear tenure; Robert Walker wrote that he had received about 5,000 letters and spoken to readers 35,000 or 40,000 times over six years; and Jim Stott claimed he had more than 35,000 calls from readers during his ten-year tenure. ${ }^{27}$

\section{Columns}

In Canada, all incumbents wrote columns. ${ }^{28}$ Columns are the public part of an ombudsman's job. In terms of media accountability, they can also be considered the main

\footnotetext{
${ }^{24}$ Mark Harrison, "Newspaper errors underline need for ways to ensure accuracy," Toronto Star, Jun. 3, 1972, p. 17. The article announcing his appointment was "Editor to represent public in newsroom," Toronto Star, May 6, 1972, p. 1. There were also a couple of one-page ads in which Harrison invites readers to write to him. See for instance one of those ads on May 8, 1972, at page 27.

25 John Brown, "A busy week with our readers," Edmonton Journal, Jul. 7, 1978, p. A5.

${ }^{26}$ Alison Downie, "Readers call - We listen; In her first week, readership editor Alison Downie learns all about cross word rage," Toronto Sun, Jun. 12, 2005, p. 2.

${ }^{27}$ Dick Goodwin, "An end and a beginning," Winnipeg Tribune, Jun. 2, 1979, p. 9; Jack Briglia, "Pictures again year's biggest problem," London Free Press, Feb. 2, 1991, p. E2; Robert Walker, "Departing ombudsman thanks readers," Montreal Gazette, May 27, 1996, p. B3; and Jim Stott, "After 30,000 calls and 400 columns - that's a wrap: Veteran journalist bids adieu after 10 years as ombudsman." ${ }^{28}$ Not all newspaper ombudsmen wrote or write columns. It was the Washington Post, the second American newspaper to employ this position, which introduced the column concept. Its example was followed by most other newspapers in the United States and abroad.
} 
element of enforcement. After all, columns can bring publicized judgements of newsroom actions, which are carried out by specific editors and/or reporters.

It is not my intent to analyse in detail the content of such columns. There have been 27 Canadian ombudsmen so far and the total number of columns would easily exceed 4,000; a thesis would be necessary just for that investigation. However, this section aims to present a snapshot of what columns can represent in an ombudsman's job, exploring what Canadian ombudsmen dealt with and where they seemed to stand on selected issues.

\section{The enforcement part of an ombudsman's job}

Some scholars (see chapter 2, pages 45 and 46) and many of my interviewees have implied "a peer surveillance" component to an ombudsman's job. That is reflected mostly by the fact that an incumbent's findings can be scrutinized by the public through a column.

This can certainly bring discomfort to those who are the subject of a column.

Gillian Steward, who was the Calgary Herald's managing editor at the time Jim Stott was ombudsman, recalls occasions when she observed anxiety from journalists who were questioned publicly. Steward says:

I think a lot of times reporters knew that Jim was looking into a case or a situation and that always made them feel a little bit nervous, right, because they didn't know how things would turn out or who was going to take the blame in his column. ${ }^{29}$

Don Sellar was aware of that and emphasizes that naming a reporter in a column was always a tough decision:

${ }^{29}$ Gillian Stewart, telephone interview, 09 Nov 2009. 
One of the hardest parts of the job is when you write a column that you have to name someone in the newsroom. That is very, very difficult because they think that you are destroying their career and really what you are doing is [fighting for] the reader. And maybe [you are] hoping to push the newsroom to higher standards. ${ }^{30}$

In exceptional cases, a public scrutiny of an ombudsman's column can go beyond discomfort. Sharon Burnside wrote once a column blaming a journalist of plagiarism, and the reporter didn't work for the paper afterwards. ${ }^{31}$

Freelance writer Carol Watts used Granfield's book to research Time Trip, a history feature published occasionally on the Starship page. All but a few paragraphs of Watts' feature, including the story of the Vicksburg paper, were taken from the book.

Facts are facts - but these facts were expressed using much of the same language and sentence structure as paragraphs in Granfield's book. Taking work that is not your own and using it, without credit, is plagiarism.

Watts has written and illustrated Time Trip since 1989. "I've never had a complaint," said Starship editor John Robinson.

Asked about the similarities, Watts said she did not intend to copy Granfield's work. "I used poor judgment, definitely."

"I'm just asking myself, 'What were you thinking?" she said. "It's heart-breaking after 16 years."

Reaching a conclusion in the Starship incident was straightforward. The material came from a single source, the text could be recognized and the writer had no proprietary right to use that material without crediting the source. ${ }^{32}$

That newsroom discomfort leads to side effect experienced by ombudsmen: a certain detachment from the newsroom, even a kind of loneliness for the incumbents. All ombudsmen interviewed have made comments related to that. In varying degrees, they

\footnotetext{
${ }^{30}$ Don Sellar, telephone interview, 22 June 2009.

${ }^{31}$ Sharon Burnside, telephone interview, 25 Jun 2009.

32 Sharon Burnside, "Plagiarism an issue of trust," Toronto Star, Oct. 15, 2005, p. H6.
} 
have all experienced distrustful reactions from reporters and editors who were being questioned by them: natural and comprehensible reaction, they generally pointed out. ${ }^{33}$ "Some of my former colleagues in the newsroom got a little wary when I wandered out there asking questions. They would get a little bit up-tighty - 'Here comes the ombudsman,' that sort of thing. I had to distance myself quite a bit," summarizes Gordon Sanderson about his experience. ${ }^{34}$

To some, the alienation was painful. Stephanie Whitaker's evaluation is a good example: "An ombudsman is someone who points out other people's mistakes, and tells people what they had done wrong, and no one wants to hang out with someone like that. So I would often have lunch alone. I felt very pained by that," she says. Whitaker recalls that one of the first complaints she dealt with involved a "special editor" [she didn't reveal his name] at the Gazette. The occurrence was quite disturbing for her and also for the editor:

I had to write out [that] complaint and I sent it to him in memo. He came into my office visibly disturbed by this. I felt that very distressing. You have to be prepared to put up with [this kind of thing] and I am not sure that I was prepared to play that role. One, because I was just young, and [second] because you do mistakes when you are a journalist, and it can happen so innocently. I always felt a little bit uncomfortable being on the other side, like I am accusing this person. There was a part of me who wondered, 'Who am I to talk with all these people that they are wrong? 35

On the other hand, there is another perspective on columns. As discussed in chapter 2 , some scholars emphasize that ombudsmen's columns are usually a public

\footnotetext{
${ }^{33}$ The distress can also be illustrated by a joke repeated by many interviewees: when an ombudsman walks into the newsroom, many journalists do the sign of the cross or hide under their desks. In fact, when making a tour around the Star newsroom with Kathy English in June 2009, I witnessed one instance in which that joke came true.

${ }^{34}$ Gordon Sanderson, telephone interview, 30 Sep 2009.

${ }^{35}$ Stephanie Whitaker, telephone interview, 16 Jul 2009.
} 
relations tool, explaining the newsgathering process more than criticizing it. ${ }^{36}$ The observation seems fair. In general, I found more columns simply elucidating the reasons something happened, than columns critical of the paper. That is not to say critical columns were lacking, however. The conclusions rested on each story's circumstances. Ombudsmen seemed to be aware of the delicacy of the matter. Larry O'Hara's farewell column, for example, reflects the concern:

I know there were many people with complaints who were not satisfied with the actions I took or the answers I gave in responding. Frequently, I felt complaints to be unjustified and found it necessary to defend the manner in which Herald staff had handled a situation. It was inevitable there would be those who saw my role as that of an apologist for the paper. ${ }^{37}$

\section{Frequency}

If columns have been such an important element of an ombudsman's job, their frequency might be seen as one measure of that importance. Overall, the columns were usually published weekly, as often stated in the announcements of the position. ${ }^{38} \mathrm{But}$, there were cases where that regularity was not met. Clair Balfour, for instance, was appointed at the Gazette, in June, 1981, but started to write a column only in December, 1982. "In the beginning I didn't write a column. There was a reason, maybe a strike [at Canada Post]. We dealt with complaints directly and the column appeared later on," Balfour says. ${ }^{39}$ Rod Goodman, Star ombudsmen, also started to write regularly only after

\footnotetext{
${ }^{36}$ See, for instance, the two articles written by Neil Nemeth and Craig Sanders on the subject: "Ombudsmen's interaction with public through columns," Newspaper Research Journal, Vol. 20, No.1, 1999, Pp. 29-42; and "Meaningful discussion of performance missing," Newspaper Research Journal, Vol. 22, No. 2, 2001, Pp. 52-64.

${ }^{37}$ Larry O'Hara, "It's been interesting - even the call from 'God'," Calgary Herald, Oct. 29, 1984, p. A10.

${ }^{38}$ Please refer to page 48 for the details of the articles announcing the position at each paper.

${ }^{39}$ Clair Balfour, telephone interview, 01 Sep 2009.
} 
two years at the job. Roger Edge, of the Chronicle Herald, wrote a column only from

time to time, but almost none in his last year:

Basically there were no new issues to talk about. There were few complaints from readers at the time and after several years I essentially ran out of interesting column ideas. I had the option of not having to produce a column every week. ${ }^{40}$

Sharon Burnside, who didn't write often, invited guest columnists, such as Kelly

Toughill, assistant professor of journalism at King's College in Halifax, and Roy Peter

Clark, a senior scholar at the Poynter Institute. She explains:

He [publisher Michael Goldbloom] said, 'If you are not writing, ask somebody in the journalist community who would write interesting pieces about the practice of journalism. Feel free to be in touch with others who would like to contribute.' In the second year, I was writing more than every other week. I was always dealing all day with phone calls and emails. You are answering questions and writing all the corrections as well. Sometimes it would be very complicated [finding the proper time to do the research and write the column]. I just found it challenging. ${ }^{41}$

\section{$\underline{\text { Topics }}$}

The purposes and themes of columns differed greatly, but the various ombudsmen seemed to reflect a similar variety in their work. The columns raised issues such as news judgement, especially of front-page stories, ${ }^{42}$ concerns related to photos (especially

\footnotetext{
${ }^{40}$ Roger Edge, email interview, 1 Mar 2010.

${ }^{41}$ Sharon Burnside, telephone interview, 25 Jun 2009 . The guest columns referred to are: Kelly Toughill, "Official 'scoops' double dupe," Toronto Star, Sep. 2, 2006, p. F6; and Roy Peter Clark, "Press deserves some respect," Toronto Star, Oct. 7, 2006, p. F6.

${ }^{42}$ See for instance: John Brown, "Public doesn't know how to read newspaper," Edmonton Journal, Jan. 13, 1992, p. A10; Clair Balfour, "Headline gave story unjustified weight," Montreal Gazette, Nov. 21, 1985, p. B3; Kathy English, "Who decides what's news?" Toronto Star, May 1, 2010, p. 6; Ray Gardner, "The headline is The Story," Toronto Star, Mar. 13, 1982, p. B2; Mark Harrison, "Headlines: They can create and compound - the error," Toronto Star, Feb. 24, 1973, p. 20; Borden Spears, "Misleading headline really
} 
involving death, accidents or funerals), ${ }^{43}$ and naming an accused person before trial. ${ }^{44}$

Common topics would also include grammar mistakes, reports on the annual conferences

of the Organization of News Ombudsmen (ONO), ${ }^{45}$ and how to write letters to the

editor. ${ }^{46}$ Rod Goodman's last column, in which he summarized the kinds of complaints

he received, makes clear how varied the topics could be:

They [the readers] have complained mildly about the size of the crossword puzzle type, fearfully about stories identifying and endangering witnesses to violent crime, sarcastically about spelling and grammatical mistakes. There have been accusations of taking sides in coverage of foreign strife, indignant cries of sensationalism in baring the private lives of people in high places, loud references to embarrassing historical gaffes, and handwringing requests to eschew photographs and stories of poor taste.

People say the paper is too prone to the bleeding-heart approach to the woes of immigrants and welfare regulars, too ready to pounce on police whenever a shot is fired, too sympathetic to

misled," Toronto Star, Jan. 27, 1979, p. C2; Robert Walker, "How we decide which stories should be on the front page," Montreal Gazette, Aug. 28, 1995, p. B3; and Roger Worth, "Perceptions not necessarily truths," Sudbury Star, Mar. 1, 1991, p. 4.

${ }^{43}$ As examples, see columns from: Jack Briglia, "Pictures again year's biggest problem," London Free Press, Feb. 2, 1991, p. E2; Ray Timson, "When public interest collides with personal privacy," Toronto Star, Nov. 28, 1981, p. B2; John Brown, "Children's photo upset many readers," Edmonton Journal, Apr. 27, 1992, p. A8; Alison Downie, "Balancing news and family privacy," Toronto Sun, Nov. 13, 2005, p. C3; Kathy English, "Public interest and private grief," Toronto Star, Jul. 12, 2008, p. A6; Rod Goodman, "Did photo of grief at policeman's funeral invade privacy?", Toronto Star, Sep. 14, 1984, p. A14; and Jim Stott, "Herald was wrong to publish photograph," Calgary Herald, May 7, 1995, p. A7.

${ }^{44}$ See, for instance: Jack Briglia, "The case against naming names," London Free Press, Jul. 3, 1985, p. A11; Ray Gardner, "Publication ban is best course," Toronto Star, May 22, 1982, p. B6; Clair Balfour, "To name or not to name, that's the question," Montreal Gazette, Apr. 11, 1985, p. B3; and Ray Tímson, "Should we name the accused?" Toronto Star, Dec. 19, 1981, p. B2.

${ }^{45}$ See for instance: John Brown, "Ombudsmen's world proves small, indeed," Edmonton Journal, May 22, 1990, p. A17; Stephanie Whittaker, "Media ethics threatened when 'scoop mania' reigns," Montreal Gazette, Jan. 30, 1989, p. B3; Roger Edge, "Got a news story? We're approachable," Chronicle Herald, Feb. 9, 2001, p. C2; William MacPherson, "Newspaper ombudsmen: they lead a lonely, arm's-length existence," Ottawa Citizen, Jun. 20, 1992, p. A13; Rod Goodman, "24 editors of my ilk swap ideas," Toronto Star, Jun. 13, 1992, p. A16; Robin Harvey, "Errors and apologies," Toronto Star, Aug. 11, 2001, p. H6; Kathy English, "Why news ombuds matter," Toronto Star, May 23, 2009, p. 6; and Robert Walker, "Errors of fact top the hate list; Ombudsmen say key job is guarding credibility," Montreal Gazette, Nov. 26, 1990, p. B3.

${ }^{46}$ See, for instance: Clair Balfour, "What The Gazette looks for in letters to the editor," Montreal Gazette, Aug. 15, 1988, p. B3; Alison Downie, "Want to see your letter in the sun?" Dec. 11, 2005, p. C3; Roger Edge, "Keep those letters coming - but be patient," Chronicle Herald, Feb. 11, 2000, p. C2; Jim Stott, "Let 400,000 readers know what's on your mind," Calgary Herald, Oct 29, 1995, p. A7; and Robert Walker, "How to improve the chances that your letter will be printed," Montreal Gazette, Sep. 12, 1994, p. B3. 
gay and lesbian aspirations (or, depending on the article, too unsympathetic).

Readers have said the newsprint is too inky; the Saturday paper is too heavy ("why can't you deliver just the sections I want to read?"); the death notices are never in the same place twice in a row; Beetle Bailey should be drummed off the comics page; the Fahrenheit equivalent is missing from the front-page temperature forecasts.

Calls and letters point to wrong pictures above captions, or wrong captions below pictures; unconscionably gory photos; photos that cruelly bare someone's private grief; stories that misquote people; editorials that shock and appal; unbalanced coverage that grinds The Star's own axes on free trade, doctors' billing limits, gun control and police cruiser pursuits. There have been variations on all these themes, making some days a steady stream of sarcasm and anger, mixed with some rage, directed to the ombudsman. ${ }^{47}$

Columns are commonly a summary of one complaint and how the newspaper dealt with it. Sometimes, they are a list of several unrelated complaints dealt by the ombudsman over the week, each discussed in a few paragraphs. ${ }^{48}$ Other times they are about a single broad issue of journalism, such as press freedom, use of anonymous sources or ethics codes. However, on the whole, this latter kind of column was less frequent, the exception being those by Borden Spears, who seemed to have the most academic or intellectual approach to what he wrote. ${ }^{49}$

\footnotetext{
${ }^{47}$ Rod Goodman, "Vigilant readers: thanks for caring," Toronto Star, Aug. 29, 1992, p. D2. See also "A year in the life of Star's ombudsman," Toronto Star, Dec. 31, 1988, p. D2.

${ }^{48}$ See for instance: Dick Goodwin, "... And we are counting," Winnipeg Tribune, Jan. 8, 1979, p. 9; Barry Mullin, "Columnist, quartets, crosswords draw complaints," Winnipeg Free Press, Apr. 24, 1992, p. A7.

${ }^{49}$ Some of Spears' columns that would illustrate this include: "Press must be critical of its criticism too," Toronto Star, Aug. 30, 1975, p. B2; "The press modestly disclaims the role of a savior," Toronto Star, Apr. 12, 1975, p. B2; and "Toward a code of media ethics," Toronto Star, Dec. 24, 1979, p. A8. Spears' columns were compiled in Borden Spears: Reporter, Editor, Critic by Dick MacDonald (Toronto: Fitzhenry \& Whiteside, 1984). However, the discussion on general topics of journalism can be found in other ombudsmen's columns as well. See, for example: Mark Harrison, "Newspaper errors underline need for ways to ensure accuracy," Toronto Star, Jun. 3, 1972, p. 17; Stephanie Whittaker, "Media ethics threatened when 'scoop mania' reigns," Montreal Gazette, Jan. 30, 1989, p. B3; and Kathy English, "Journalism and Jiminy Cricket," Toronto Star, Apr. 19, 2008, p. A4.
} 
Another unusual kind of column discussed news missing from the newspaper.

This finding coincides with an observation by Peter Calamai, a former managing editor of the editorial page at the Ottawa Citizen and an adjunct research professor at the School of Journalism and Communication at Carleton University. Calamai points out:

One of the hardest things for ombudsman to tackle is what doesn't get reported, not what does get reported. If you want to really start raising the eyes of publishers, start writing about the fact that they don't spend any money to maintain foreign news coverage [for example]. In theory, they [ombudsmen] can do that. They have the mandate to do that. Bill [McPherson] never did. Don [Sellar] never did. Kathy English hasn't. Sharon [Burnside] may have done once or twice. Now Jeffrey Dvorkin did when he was working at the Public Radio in the United States. The New York Times has done it numerous times, so has the Guardian. Also: writing about failures of omission [asking questions such as] 'why were we so late to cover that story'? If that is what the person is doing then, yes, it definitely is worth having it [the position]. ${ }^{50}$

I found, among Burnside's columns, one that would "raise a publisher's eye," as

Calamai put it. It was a column about the resignation of Star publisher Michael

Goldbloom and editor-in-chief Giles Gherson, virtually unreported by their own paper in contrast to others, such as the Globe and Mail and National Post. Burnside wrote:

Why the dramatic contrast in coverage between the Star and the others?

The simple answer is that newspapers often have great difficulty writing about themselves. This is not a failing peculiar to the Star.

And commentary was missing from Star coverage because the media columnist, Antonia Zerbisias, was away.

The key is to ask How would the paper cover the story if it was happening to someone else? The paper would have chased it.

I think Star readers deserved an analytical story, particularly in the midst of a high profile marketing campaign themed, "Ask Why."

\footnotetext{
${ }^{50}$ Peter Calamai, telephone interview, 22 Oct 2009.
} 
What were market analysts saying? Where was the reference to the Moody's Investors Service Inc. downgrading? Were the board members asked to comment?

Even if there was no chance board members would talk, aggressively pursuing the story would have demonstrated that the paper applies the same standards to itself that it does to others.

Perhaps independent comment could have been invited. This story was a test of the newspaper's ability to offer unbiased coverage. Trust will erode if readers think the paper treats itself more gently than everyone else. ${ }^{51}$

Stephanie Whittaker, of the Gazette, wrote a similar column. It was about the lack of information and precision in print coverage of the suicide of Ken Adachi, a former Toronto Star book reviewer. Adachi left the Star after being accused of plagiarizing a 1982 Time magazine essay. He was found dead in his home four days later; the death was ruled a suicide. Toronto Star published a small article stating that he had resigned from "his position as The Star's literary critic following complaints to the paper that he failed to attribute parts of a recent review." ${ }^{52}$

Whittaker asks: "Are newspapers circumspect when reporting on their own people? Do journalists close ranks around their colleagues, according them more privacy than they would give Joe Public?" She also denounced her paper: "The Gazette's version of the story, which was six paragraphs long, was woefully inadequate. It was redeemed by a full-page feature about Adachi written by Mark Abley and published a week later."53

It was also atypical to find columns that purely complimented the paper for what it had accomplished. A rare example by Robin Harvey describes how the Star was performing its job "right":

\footnotetext{
${ }^{51}$ Sharon Burnside, "Star coverage failed vital test," Toronto Star, Oct. 21, 2006, p. F6.

52 "Top critic Ken Adachi dies at 60," Toronto Star, Feb. 11, 1989, p. A3. There was no column from ombudsman Rod Goodman about the subject.

${ }^{53}$ Stephanie Whittaker, "Newspapers shrink from reporting on themselves," Montreal Gazette, Mar. 6, 1989 , p. B3.
} 
There is more to being a newspaper reader's advocate than letting people know when and why problems and mistakes occur.

Sometimes it is good to let readers know what the paper is doing right.

In recent weeks, there has been much to be proud of in The Star's coverage. Readers have been challenged, enlightened and entertained in every section. The paper has had some shining special sections, excellent columns and tackled substantive issues and controversies.

One of The Star's strengths is telling the stories of people who may be marginalized. Two recent stories accomplished this very well.

Leslie Scrivener produced a sensitive look at Islamic schools in Toronto that shed light on a community that at times has been the subject of stereotypes and prejudice.

The story explained the foundations and values behind the growing demand for schools that teach spirituality for Muslim Canadian. Besides being an insightful and well written piece, it reflected the paper's commitment to portraying our city's growing multicultural makeup. ${ }^{54}$

In this column, Harvey refers to six other journalists' accomplishments and also mentions in general the "good" coverage of the Olympics, and how the paper increased the number of obituaries it published about women.

Sharon Burnside says one complimentary column she wrote did not appear on the advice of publisher Michael Goldbloom. It praised a retiring Star journalist. "Michael's concern was that the piece was too positive and that my credibility would be damaged," she explains. ${ }^{55}$ Complimentary columns carry always a risk, according to Don Sellar: "It is a fact that newspapers do some things right and the columns needed to project that. But if you do it all the time, then you are becoming an apologist for the newspaper." 56

Ombudsmen also cited their peers from other papers. (That was how I discovered that the Winnipeg Tribune once employed an ombudsman: John Brown in Edmonton

\footnotetext{
${ }^{54}$ Robin Harvey, "Some proud coverage in recent weeks," Toronto Star, Mar. 10, 2001, p. J6.

${ }^{55}$ Sharon Burnside, telephone interview, 25 Jun 2009.

${ }^{56}$ Don Sellar, telephone interview, 22 Jun 2009.
} 
discussed how a Tribune ombudsman dealt with complaints about the format of a crossword puzzle. ${ }^{57}$ ) Coincidentally, the reference went the other way when Dave Cross discussed how Brown treated a complaint about describing Pierre Trudeau as a "lame duck," accepting Brown's explanation as his own. ${ }^{58}$

One relatively common type of column found was "You be the editor." Don Sellar employed it three or four times a year, ${ }^{59}$ but Sharon Burnside, Kathy English, Gordon Sanderson and Robert Walker also used it. ${ }^{60}$ Sellar states that it was not only a way to get readers thinking about difficult situations that editors face; it was also a way of gaining journalists' attention to some newsroom policies. "I would set up a case largely based on the facts. I would usually use three cases in the column. It was not hard to find good examples or cases that needed to be brought to newsroom attention," he says. Feedback was solicited and published from readers. ${ }^{61}$

${ }^{57}$ John Brown, "Solution through compromise," Edmonton Journal, Jan. 4, 1980, p. A6. To my knowledge, no study, journalism review or newspaper article on ombudsmanship has previously mentioned the Tribune ombudsmanship.

${ }^{58}$ Dave Cross, "Sparse rural coverage deplored," Winnipeg Tribune, Dec. 29, 1979, p. 9. For more examples of ombudsmen citing their peers, see: Stephanie Whittaker, "'Inane' story was designed to provide amusement," Montreal Gazette, Mar. 27, 1989, p. B3; William Gold, "Listening, Ralph Ponskum? Don't call me again," Calgary Herald, Sep. 4, 1985, p. A11; Roger Edge, "Occasionally, change is for better," Chronicle Herald, Jun. 1, 2001, p.C2; Jim Stott, "More journalists should 'bleed over their mistakes'," Calgary Herald, Dec. 24, 1995, p. A7.

${ }^{59}$ See, for instance, Sellar's columns of April 5, 1997, p. B2; August 30, 1997, p. B2; December 13, 2003, p. E6; March 13, 2004, p. F6; July 24, 2004, p. H6; and December 18, 2004, p. H6.

${ }^{60}$ As an example of each: Robert Walker, "How would you make these four editorial decisions?" Montreal Gazette, Mar. 25, 1996, p. B3; Kathy English, "Readers, now you be the editor," Toronto Star, Jan. 3, 2009, p. A4; and Sharon Burnside, "You be the editor," Toronto Star, Dec. 26, 2005, p. A29. Gordon Sanderson stated that his column "You be the editor" received the most feedback from readers, but I didn't come across that particular column in my research. (Telephone interview, 30 Sep 2009.)

${ }^{61}$ Don Sellar, telephone interview, 22 Jun 2009. 


\section{Styles and patterns}

Readers would often voice their opinions when calling ombudsmen. The latter would listen and, based on their paper's side of story, express an opinion. But where did the ombudsmen usually stand?

From the sample columns gathered, I observed several patterns. First, they could be hard-line in pointing to a paper's mistake, as was usually the case with Barry Mullin and Ray Gardner, or much softer, as was normally the style of Roger Edge and Roger Worth. In Edge's case, I couldn't find one column critical of his paper among those sampled; and in Worth's case, I found just one. ${ }^{62}$

Mullin, by contrast, declared in a column that one front-page story contained an error of news judgement. Mullin seemed to have found the error dreadful and wrote about it in a satirical way:

Some lapses in news judgment are more obvious than others. Yesterday's temporary failure to recognize the eruption of violence in Los Angeles that followed the acquittal of four white police officers for the widely shown videotaped beating of an Afro-American as the most important news event was shocking.

The first 30,000 to 35,000 papers off the presses feature a front page story and color photo about two young heroes. The trouble in L.A. made headlines on page D-56. About half those papers went to communities in northern Manitoba. The other half were marked for home delivery in Winnipeg.

Sure the unbylined heroes' piece ranked as a "good news" story. It deserved some play. But sound news judgement simply couldn't be creatively stretched enough to consider that bit of soft news a candidate for one of the most prominent places in a newspaper or to rank it above the unfolding calamity in L.A. ${ }^{63}$

\footnotetext{
${ }^{62}$ Roger Worth, “Did The Sudbury Star mislead readers?” Sudbury Star, Jul. 8, 1992, p. A6.

${ }^{63}$ Barry Mullin, "Some subscribers missed front-page L.A. riot story," Winnipeg Free Press, May 1, $1992, \mathrm{p}$. 7. This column was the last one written by the ombudsman. As we shall see in chapter 5 , there was a controversy over it, and Mullin resigned.
} 
Gardner wrote a column about a case in which Star reporter Jack Cahill was said to have plagiarized prior work by freelancer Jon Newton. Rejecting Cahill's justification, Gardner says he urged Cahill to write a "forthright apology." In his column, the ombudsman continues:

He did write one grudgingly apologetic letter, but I found it unsatisfactory because it apologized only for 'upsetting' Newton. Finally, he decided not to apologize to Newton in any form.

Of Newton's work, Cahill wrote, "It's hardly literature or even golden phraseology."

That may be true, but still it was good enough to appear under the byline of Jack Cahill.

This column can be taken as an apology to Newton for the unacknowledged use of his material. It also attests to the fact The Star finds Cahill's explanation unacceptable. ${ }^{64}$

As experienced journalists, ombudsmen have tended to give their opinions from the perspective of the profession, raising frequently the differing viewpoints between media and non-media people. This is not to say that ombudsmen disagreed with readers' view. On the contrary, they agreed in many cases ${ }^{65}$ - especially if the complaints were about factual errors (precision in numbers, grammar mistakes, misspelled names, etc.) or plagiarism. The examples abound, in fact, but they vary according to the complaint's nature and the circumstances around the reportage.

In one single column, for instance, Jack Briglia pinpoints three readers' complaints. In two instances, he agrees with readers (and sources): first, Briglia says that

\footnotetext{
${ }^{64}$ Ray Gardner, "Much too close for comfort," Toronto Star, Apr. 10, 1982, p. B2. Jack Cahill is deceased; his obituary highlights his achievements as foreign correspondent and award-winning journalist. (Patrick Evans, "Jack Cahill 'He was one of the last old-time journalists'; Globe- trotting reporter, author dies at age 79 Best way to get a story was 'to see it, feel it, touch it'," Toronto Star, Jul. 7, 2005, p. A10.)

${ }^{65}$ See for instance: Dick Goodwin, "Score for lawyer, zero for CP and us," Winnipeg Tribune, Sep. 13, 1975, p. 9; Ray Timson, "Lady Luck didn't smile for us," Toronto Star, Jan. 2, 1982, page B2; Don Sellar, "U.S. article was plagiarized," Toronto Star, Apr. 15, 2004, p. A24; Roger Worth, "The ombudsman: yes, we do want to hear from readers," Sudbury Star, Sep. 14, 1990, p. A5.
} 
an action line columnist was unfair because he didn't present necessary background information available from the industry attacked; second, he writes that a headline contained a term that was not accurate, as pointed out by a reader. In the third case, Briglia sympathizes with the paper. It was a matter whether the word "stupid" used in a headline was harsh; the ombudsman concludes the headline was justified because the expression was cited more than once in the text by the main source in self-evaluation. ${ }^{66}$

But when the matter was news judgement, the propensity was, if not to favour the paper in particular, to favour journalism in general. ${ }^{67}$ Could it be otherwise? Probably not. As Jim Stott pronounced in one of his columns:

Whatever else may change, there's one thing about this business which I think will remain a constant. Readers and editors frequently disagree on both what is news and the relative importance of various news events. ${ }^{68}$

In a similar vein, Mark Harrison reflected on readers' perceptions of biased

stories:

But what is bias? It often lies in the eye of the beholder. When a reader accuses a newspaper of bias, what he sometimes means is that it reflects an opinion with which he disagrees. When he says a newspaper is objective, what he really means is that it reflects a view-point with which he agrees. ${ }^{69}$

\footnotetext{
${ }^{66}$ Jack Briglia, "If readers aren't given the facts they get the wrong idea," London Free Press, Feb. 6, 1985, p. A15.

${ }^{67}$ See for instance: John Brown, "Public doesn't know how to read newspaper," Edmonton Journal, Jan. 13, 1992, p. A10; Kathy English, "Who decides what's news?" Toronto Star, May 1, 2010, p. 6; Stephanie Whittaker, "Decision on space agency story was not partisan," Montreal Gazette, Mar. 13, 1989, p. B3; Roger Worth, "Why are some stories given prominence?" Sudbury Star, Sep. 6, 1991, p. 6; and Chris Krejlgaard, "Would the Star follow politicians' affair?" Sudbury Star, Mar. 19, 1993, p. A6.

${ }^{68} \mathrm{Jim}$ Stott, "Readers, editors seldom agree on news," Calgary Herald, Feb. 28, 1993, p. A7.

${ }^{69}$ Mark Harrison, "We try to be fair - but it's in the eye of the beholder," Toronto Star, Dec. 16, 1972, p.
} 22. 
That is also the case when ombudsmen discussed readers' complaints about columnists. They tended to not include themselves in the matter, explaining that columnists are paid to publish their opinions, which will obviously differ from those of part of the audience. "Columnists are the yeast in the paper. They stir the pot, and get people thinking," Don Sellar once wrote, which summarizes the essence of other ombudsmen on the subject. ${ }^{70}$

Overall, ombudsmen tended to cite the names of reporters and/or editors in order to incorporate their perspectives or explanations on whatever issue was being discussed. But some of them chose not to cite names, making reference just to the story; these included Mark Harrison, William Gold and Jim Stott. Each justified that choice in columns. Stott, for instance, wrote: "Members of the staff who in my judgment have erred will likewise remain anonymous in the column, since the purpose of criticism will be to seek improvement, not hand out public reprimands to individuals.",71

The discussion of photos, a frequent subject in ombudsmen's columns, may illustrate all of the above: comments can be hard or soft, ombudsmen tend to give their opinions from a journalistic perspective, opinions vary according to the circumstances, and editors and reporters are cited mainly to convey their point of view.

John Brown, for example, discusses a front-page picture in which two children watch a police officer, armed with a rifle, waving for help for an injured man (their

\footnotetext{
${ }^{70}$ Don Sellar, "Let's put columnists on a diet," Toronto Star, Nov. 13, 2004, p. H6. Other columns that explore the issue of columnists include: William MacPherson, "Columnists are expected to state strong opinions," Ottawa Citizen, Jun. 9, 1990, p. B7; Roger Edge, "Sunday columnists take heat from readers," Chronicle Herald, Mar. 24, 2000, p. B2; William Gold, "Columnist's criticism of left fulfilled role," Calgary Herald, Jan. 3, 1985, p. A10; and Larry O'Hara, "Professional reviewers needn't agree with the audience," Calgary Herald, Jan. 4, 1983, p. A7.

$71 \mathrm{Jim}$ Stott, "It's time for this ombudsman to fly alone at the controls," Calgary Herald, Sep. 05, 1985, p. A11. See also Mark Harrison, "Newspaper errors underline need for ways to ensure accuracy," Toronto Star, Jun. 3, 1972, p. 17; and William Gold, "News stories, headlines must maintain discipline," Calgary Herald, Nov. 15, 1984, p. A10.
} 
father), who is crouching on the ground outside their home. The siblings, aged 4 and 5 , were sent out of the house while their father shot their mother and wounded her boyfriend. Readers expressed concerns that the photo would add to the children's

distress. Brown quoted a couple of these concerns and the editor's explanation for the use of the picture. He concludes:

The ombudsman agrees with the editor on this one. It was an extremely powerful photo that caught the dreadfulness of what happened. The suffering of these little children brought home the horror of the ultimate act of family violence.

The media sometimes are insensitive to the plight of victims. But it can only be speculation in this case whether the photo added to the children's distress. As readers noted, they were innocent spectators. The shot did not show them in any sort of degrading way. ${ }^{72}$

Similarly, in a 2005 column Sharon Burnside examines a controversial front-page photograph a man - actually just parts of his body (a foot, a leg and part of his torso, as she describes it) - killed in the debris of a building flattened by Hurricane Katrina. Burnside explains the Star policy on publishing photos of bodies, and how discussion about the picture evolved during the afternoon and evening prior to its publication. She summarizes the opinions expressed by readers and quotes the publisher and editor-inchief. Burnside compares the Star with other newspapers, such as the New York Times and National Post, which have also run photos of dead people on their front pages, and concludes:

There is no one-size-fits-all guideline to apply in these situations. Each photograph must be decided on its own merits and circumstances. I always found it helped to consider how I would explain my choice to upset readers the next day. In this case, the

${ }_{72}$ John Brown, "Children's photo upset many readers," Edmonton Journal, Apr. 27, 1992, p. A8. 
arguments from the journalism universe did not persuade readers. And they did not persuade me.

The devastation in Biloxi could have been captured in a photograph without a body.

The readers I talked to did not object to the photo because they wanted to be protected from the truth. They objected to the photo because they believed that respect for the dignity of the dead man in the picture was more important.

I believe the readers were right. $^{73}$

A third example: Ray Timson discusses whether a story about a former Provincial Court judge who pled guilty on a minor shoplifting charge was an invasion of privacy.

The story ran with a photo, taken with a telephoto lens from across the street and through the window of a hotel room where the judge was living. The background of the story in fact was not about the shoplifting charge per se, but the case in which alcoholism turned someone's life upside down. Timson explains how and why the story captured the attention of two reporters, and cites the point of view of the two photographers and executive editors involved in the issue, along with the opinion expressed by a couple of readers. In the end, he writes:

The Star's ombudsman is of two minds here. After 25 years in an operational role in the newsroom, I would have run the story and the picture. After one year as an ombudsman, listening to the readers, I might have mellowed and spiked it. ${ }^{74}$

\section{The effectiveness of the position}

In this section I explore the effectiveness of the ombudsman's position upon the views of incumbents, publishers, editors and journalists. The main purpose is to present

\footnotetext{
${ }^{73}$ Sharon Burnside, "Photo of body offended readers," Toronto Star, Sep. 3, 2005, p. F6.

${ }^{74}$ Ray Timson, "When public interest collides with personal privacy," Toronto Star, Nov. 28, 1981, p. B2.
} 
their general perceptions on two important questions: How well did the newsroom support the new post? And what was the position's impact on journalists?

Overall, my interviewees were supportive of the position. Even those who said they didn't like the ombudsman idea acknowledge that there was some usefulness in it. Former Winnipeg Free Press managing editor Murray Burt is a good example:

Other than window dressing, I don't think he [Barry Mullin] did a great deal for the Free Press. Now having said that, I give him credit for this: it made everyone more sensitive to the fact that they were answerable and likely to be quoted and answer for what they wrote. $^{75}$

Reporters were generally more sceptical than editors about the effect that the position had on their work, but they too seemed to see some value in it. Catherine Ford, former columnist and long time employee of the Calgary Herald, for instance, says that she doesn't believe the paper's ombudsmen made journalists work more carefully - not her, at least. But she says there was general acceptance of the idea - as long as the journalist didn't hear from the ombudsman:

Journalists do not take criticism very well. And so the ombudsman was always seen as someone who was coming around making your life miserable because you wouldn't hear from him from one day to the next unless there was a problem. I shouldn't speak for other journalists, but we knew the value of an ombudsman simply because if you have one then you were seen to be fair to the readers, that if the reader had a complaint he could go to the ombudsman and the ombudsman would investigate it on the behalf of the reader, and then would publish the results of his investigation. If they [journalists] were the focus of the complaint

\footnotetext{
${ }^{75}$ Murray Burt, telephone interview, 26 Sep 2009.
} 
they would say something or grumped about it. But most of the time we appreciated. ${ }^{76}$

Jim Cunningham spent twenty-two years working at the Herald. He agrees with

Ford that the position didn't have much influence on journalists' work, but affirms that

ombudsmanship was something viewed as a way for editors to avoid angry readers:

Overall, I and others in the newsroom shared a sense that these individuals were there to help the newspaper deal with complaints from the public that were of a persistent nature, and required some negotiation. In effect, the ombudsman was there to spare others in management the chore of dealing with these complainants themselves. It is fair to say, however, that none of the three [ombudsmen] was strongly, or consistently critical of editorial practice. This led to the impression that none of the three had much real impact on what we did. I also had the impression that, when the chips were down, senior staff would deal with important problems with news coverage themselves and consult directly with us, basically going around the ombudsman's office. ${ }^{77}$

Several Ottawa Citizen employees at the time of William MacPherson's ombudsmanship - Peter Calamai, a former editorial page editor; Christina Spencer, former city editor; Don Butler, former assistant managing editor; and Charles Gordon, a former columnist - assert a similar point. Management had created the position to find a job for MacPherson, a long time employee approaching retirement. They say the ombudsman was not very critical of editorial practices, and therefore had no impact on

\footnotetext{
${ }^{76}$ Catherine Ford, telephone interview, 12 Nov 2009; email interview, 13 Jul 2010. Ford adds she never had her work scrutinized by any of the three ombudsmen, and couldn't remember any specific detail with any of her colleagues: "I've been wracking my brains trying to think of a concrete example for you and have come up empty. Mostly it was grousing about having to defend yourself against what some saw as nit-picking and others saw as questioning the professionalism of one's work. Sorry that I can't supply chapter and verse, but it has been a good number of years and one tends to 'forget to remember' criticism."

${ }^{77} \mathrm{Jim}$ Cunningham, email interview, 01 Dec 2009. Cunningham said he couldn't remember a specific example.
} 
journalists, but his columns were somewhat useful in helping readers understand newsgathering practices. ${ }^{78}$

Citizen columnist Dave Brown wrote about MacPherson's role after one year's tenure. Brown, who had 33 years of newspaper reporting experience, declared that the ombudsman did have an impact on his way of working:

Indeed, it wasn't long after his appointment that I looked up and saw MacPherson standing in my office. He wanted to know if moments earlier I had been short with a female caller. Specifically, he wanted to know if I had called her a crank case.

I replied I had not.

However, I admitted I had become exasperated with a female caller who wouldn't give up. She was trying to sell a line of thought I wasn't buying. She was insisting I support a cause I didn't agree with.

I was having a cranky day.

I confessed to MacPherson that I called the woman a dipstick. It was embarrassing. I have to have much more patience. I often give my job description as professional listener.

Name-calling isn't professional. The expression on MacPherson's face made it clear I had stepped over a line. I had already apologized to the woman. I said I would do so again if he thought it was in order.

He said he would talk to her, and left without saying whether I could expect to see my gaffe reported in his weekly column. But with 2,000 calls and 600 letters crossing his desk in his first year of operation, this one slipped by.

I learned the presence of an ombudsman does make a difference. Writing a daily column can be a pressure cooker. One never loses the fear of open newspaper space. MacPherson himself acknowledges that he still hasn't adjusted to that fear of space.

One of the situations that makes me cranky is the never-ending "meeting." An organization appoints a person to handle questions from the media, and that person gets tied up in meetings, and won't step out to answer questions.

Newspaper deadlines don't creep up. They come crashing down. A company official who isn't available to speak leaves a hole.

\footnotetext{
${ }^{78}$ Charles Gordon (telephone interview, 24 Sep 2009), Christina Spencer (telephone interview, 30 Sep 2009), Don Butler (telephone interview, 13 Aug 2009), and Peter Calamai (telephone interview, 22 Oct 2009).
} 
Is it fair to run a story without a comment from the company? Is it fair of the official to expect somebody under a deadline to wait indefinitely?

Having an ombudsman down the hall has changed things. I now make much more of an effort to make contact with "media relations" officials.

In the past, more than one spokestype has seen critical comment in this column, and called to complain that he didn't get a chance to tell his side.

So show some sympathy for deadlines and come out of meetings.

Such complaints get a more sympathetic hearing, now that there's a person assigned to listen.

I now go to greater lengths to make contact. MacPherson can be tough, and I'd rather avoid him.

I asked him the other day how many times he would hear complaints that a writer was unfair before he'd get tough.

"If I heard that complaint twice, you'd be looking at serious trouble."

I've always tried to be fair. But with an ombudsman around, it's now mandatory. ${ }^{79}$

As a reporter, Robin Harvey (herself a former ombudsman) had three stories

scrutinized by ombudsman Don Sellar. One involved getting reaction from a number of municipal officials to a major news event. The story had to be written quickly, and she confused a quote from one official with that of another:

When I flipped the page, I thought I was still on the notes from the first official, when in fact I had already moved to the notes for the second official interviewed. The content of their reactions were very similar. But rightly so, the first official called Don and said he had been misquoted. Don was very calm and supportive and asked me to review my notes. When I did, I immediately saw my error. ${ }^{80}$

Instead of being upset about the scrutiny her stories received, she came to believe the position was helpful:

\footnotetext{
${ }^{79}$ Dave Brown, “Ombudsman makes me work harder," Ottawa Citizen, May 27, 1991, p. C1.

${ }^{80}$ Robin Harvey, email interview, 15 Apr 2010.
} 
When it [the position] works, it has the success of giving the reporter the security of knowing that they don't have to worry about expending energy with frivolous and malicious attacks against you when you are doing your job correctly. It also gives the reporter the confidence that, if they are wrong, they will be dealt with a nice tidy way and things move on. ${ }^{81}$

Henry Stancu and Denise Balkissoon, the Star reporters involved in the wrongful identification of a murder victim cited in the introduction, share similar opinions. Both say that the ombudsman's job is helpful in making them learn from the mistakes and not repeating them again. They also believe the position is positive for readers and other newsroom staff, including editors. Stancu says:

I do feel that Kathy's work often impacts journalists (reporters, columnists, editors and photographers) here at the Star because it often highlights gaffes and pitfalls in our business. Even when there is little time in the face of deadlines, we have to be certain of the facts and aware of the effect, on real people, of what we do. In our business getting it right is paramount. There will always be factual corrections and apologies to be made for mistakes, but if we deal with errors quickly and honestly readers will respect us for it. $^{82}$

Nevertheless, it is easy to find other perspectives.

Bob Hepburn and Ian Urquhart, currently communications editor and editorial page editor at the Toronto Star respectively, say that as reporters or editors they didn't like having their stories questioned. Urquhart mentions that when he was a street reporter, he would listen to many staff complaints about ombudsmen. "Reporters don't like to have their copy challenged. It's a natural feeling," he adds. ${ }^{83}$ They both say they support the position nowadays, however. Could this be an indication that the effectiveness of the job

\footnotetext{
${ }^{81}$ Robin Harvey, telephone interview, 15 Oct 2009.

${ }^{82}$ Henry Stancu, email interview, 20 Aug 2010. Denise Balkissoon was interviewed by email on August 16, 2010.

${ }^{83}$ Bob Hepburn and lan Urquhart, in person interviews, 16 Jun 2009.
} 
will depend not only on who the ombudsman is, as media scholars have emphasized, ${ }^{84}$ but also on which journalist is giving an opinion, as we saw in comparing Brown, Harvey and Urquhart's statements, for example? It seems that yes would be a fair answer here. Yet, I cannot measure how useful an ombudsman's scrutiny can be to a journalist's career. Nor could any of my interviewees.

Overall, though, ombudsmen seem confident of their impact. Stephanie Whitaker, the Gazette's second ombudsman, for instance, says the position can make a difference in the newsroom:

It acts as a kind of conscience - that is not to say that journalists do not have conscience. They are hard working people, who care about the truth. The ombudsman is there as a reminder that we have this critical confidence with our readers and it is really important to honour that. ${ }^{85}$

Others, such as Gordon Sanderson, Sharon Burnside, Robin Harvey, Kathy English, Don Sellar, Roger Edge, and Clair Balfour, on the whole share that feeling.

\section{Other ombudsmen have their say}

Other news ombudsmen were asked to give their thoughts on the impact of their job, in order to see if their opinions differ from those of newspaper incumbents. It turns out they are even more confident of the utility and effectiveness of their job.

Vince Carlin has been CBC's English-language ombudsman for more than four years. He worked for CBC in several positions, including chief news editor, and taught

\footnotetext{
${ }^{84}$ See for instance: Andrew Cline, "Ethics and Ethos: Writing an Effective Newspaper Ombudsman Position," Journal of Mass Media Ethics, Vol. 23, No. 2, 2008, Pp. 79-89; Christopher Meyers, "Creating an Effective Newspaper Ombudsman Position," Journal of Mass Media Ethics, Vol. 15, No.4, 2000, Pp. 248256; and Neil Nemeth, News Ombudsmen in North America: Assessing an Experiment in Social Responsibility, Praeger: Westport, Conn, 2003.

${ }^{85}$ Stephanie Whitaker, telephone interview, 30 Sep 2009.
} 
journalism for eight years at Ryerson University before returning to the broadcaster as its ombudsman. He does believe the position has an impact on journalists:

One of the things that surprised me when I came back [to CBC] was the sense among journalists that they have to be careful, aware of policy because the ombudsman is there. It is interesting that it is part of their thinking as they are doing a story; what this independent observer is going to think. That is a good thing, a useful thing. It shouldn't be inhibiting journalism, they shouldn't feel like somebody is looking over their shoulders all the time. I see that much more now than when I was in junior positions before they had an ombudsman. Mostly when I heard from journalists in the front line they have a sort of laugh and say, 'I thought this might get a complaint to the ombudsman,' if they are doing a story that is particularly provocative or emotional. I haven't got the sense they were worried about it. Generally it is a positive thing. ${ }^{86}$

Although in essence the job is the same, CBC's ombudsmanship has some

differences. There is a five-year contract, which can be renewed once. She/he can be fired only for "dereliction of duty or gross misconduct," as stated on the CBC website. CBC has also established two ombudsman offices: one for English networks (Carlin) and one for French (Julie Miville-Dechêne). ${ }^{87}$

Under the CBC's complaints process, the complainant is encouraged to first contact the offending program, and only if not satisfied with that reply go to the

\footnotetext{
${ }^{86}$ Vince Carlin, telephone interview, 26 Oct 2009.

${ }^{87}$ The $\mathrm{CBC}$ website provides information on the mandate, jurisdiction and appointment of its ombudsman. It also carries its policy on journalism standards and practices, and the findings and annual reports of its ombudsmen. [http://www.cbc.ca/ombudsman and www.radio-canada.ca/ombudsman] in addition, CBC officially created the post of ombudsman in 1991, although this was preceded by the appointment in 1989 of William Morgan as Director of the Office of Journalism Policy and Practices (for the English Services), according to Laura Marshall, assistant to the CBC ombudsman. (Email interview, 12 Mar 2010.) Radio Canada adopted the position in 1992. Julie Miville-Dechêne, appointed in April 2007, is the first woman incumbent.
} 
ombudsman office. When the audience member goes to the ombudsman first, the

program still has the right of initial response. ${ }^{88}$

The first thing we do is we require sharing it [the complaint] with the program involved. By policy the programmers responsible for the item have the right to respond first. We tell the person who is complaining that we are going to share it with the editor-in-chief of the CBC News along with the request that their concerns be addressed. The programmers are given 20 business days to respond and by and large they do fit in that time period. Most, they do make it. If the person is not happy with that response, if it is not satisfied by it, then they are free to address me again and ask for an independent review. Mostly complaints go away there. People accept the explanation of the programmers because quite often the complaints have misheard what was reported or they attributed to a CBC journalist something that was said by an interview subject and a whole lot of things. People just don't hear it right or don't see it right. Most complaints go away there - ninety per cent. Sometimes they don't agree with the response but say, 'I am not going further with it.' But if they ask me to review, I do review as quickly as I can. ${ }^{89}$

But the independence of the position is something even more important to

emphasize, according to Julie Miville-Dechêne:

I would say that a mandate is important because in my case they [management] cannot finish my employment in that period of five years for what I write, even though they can be angry with a review. If you have no fixed mandate, it seems to me that the risk is a little bit higher. If the ombudsman becomes too loud, too critical, they can just decide to shift the position. ${ }^{90}$

\footnotetext{
${ }^{88}$ By contrast, Roger Edge, of the Chronicle Herald, was announced as a second route of appeal for complaints that were not "resolved through normal channels." ("Ombudsman appointed," Chronicle Herald, Jan. 16, 1993, p. 1) The same was true at the London Free Press when its second ombudsman, Gordon Sanderson, was named (Philip McLeod, "A new approach to readers' complaints," Feb. 9, 1991, p. E2). However, in fact, Edge and Sanderson say the majority of their time was spent with "first hand" complainants.

${ }^{89}$ Vince Carlin, telephone interview, 26 Oct 2009.

90 Julie Miville-Dechêne, telephone interview, 29 Oct 2009.
} 
Carlin agrees: "It is useful for the public to see that there is a guarantee that the ombudsman is independent; that there is protection for the person." He also notes that neither the English nor French ombudsman can be hired back by the $\mathrm{CBC}$ for at least two years after the expiration of their contract. "I don't mind the blackout period in the end, because it should be clear that I don't have any personal considerations in the reviews [such as] to get a nice job in the end." 91

CBC's model was copied in the United States by National Public Radio. Jeffrey Dvorkin, who was the first NPR ombudsman, affirms that the scope of his job was borrowed from the CBC's mandate. "I wrote the job description. I basically took the definition of ombudsman from the CBC which I thought it was an excellent description of the independent role of the ombudsman," he recollects. ${ }^{92}$

Similar conditions are found at the Washington Post, the second American newspaper to adopt the position. At the Post, there is also a contract - in this case for two years, renewable for one more year - and a blackout period, as it has in CBC's model.

Andrew Alexander, current Post ombudsman, affirms that the terms are good because they emphasize the independence of the job and guarantee fresh ideas from a new ombudsman every two or three years. Although Alexander says it is difficult to measure the effectiveness of the position, he thinks it is successful in several ways:

I am very convinced that the role of an ombudsman - not just the way I perform, but the role of an ombudsman - is very valuable. There have been things I have written here, columns, that have eliminated things that needed to be corrected in the newsroom and the Post had taken steps to correct them. Journalists in the newsroom who know that there is one independent person looking at their work and has the potential to write a column about it that

\footnotetext{
${ }^{91}$ Vince Carlin, telephone interview, 26 Oct 2009.

92 Jeffrey Dvorkin, telephone interview, 22 Oct 2009.
} 
would be seen by hundreds of thousands of readers, or more than a million of readers probably - they are less inclined to cut corners, I think. That doesn't mean that they do occasionally. That is human nature, but I think having someone with sort of the moral authority of an ombudsman, I think it helps. It builds reader credibility in the news organization because you are holding reporters accountable. You are representing the interest of readers who often feel that they don't have a voice in the newspaper and, after all, they do pay for it. And if you can help raise the standards of the newspaper by making the newspaper more credible, then more readers will want to read it. I say that but I don't know if there is absolute evidence by the ombudsman trying to raise the standards makes more people read the paper. But I do know instinctively that if the standards are lower, more people will abandon the newspaper. ${ }^{93}$

These news ombudsmen suggest that the model of ombudsmanship used by a news organization can increase ombudsmen's own confidence in how well they perform their job, and their confidence the role is perceived as a trustful one by the audience.

I have asked many of my interviewees to compare the model of ombudsmanship at their own paper with that at the New York Times. Most answers have been mixed: each model has its pros and cons, they say, without reaching a conclusion about the impact of each model on the effectiveness of the position. The one exception was Star editorial page editor Ian Urquhart, who said:

I think by reading the columns of the New York Times, there were times that he proceeds as if he is the enemy [of the paper]. In our case, this person is an employee of the paper, not an enemy. And he/she has to accommodate [to that structure]. We are comfortable in our model, we like the way it works. ${ }^{94}$

\footnotetext{
${ }^{93}$ Andrew Alexander, telephone interview, 27 Oct 2009.

${ }^{94}$ Ian Urquhart, in person interview, 16 Jun 2009. I have tried to interview Clark Hoyt, who was the public editor for the New York Times from May 2007 until June 2010. My request was not responded to, even though his assistant at the time, Michael McElroy, said I would hear from the public editor's office one way or the other.
} 
Arguments favouring the Canadian ombudsmanship model would include this: A long-time employee would know the culture of the newsroom and staff well, which could lead to faster investigation of complaints; ombudsmen would know where to go to ask questions, and it would be easier to get collaboration. But there is a flipside: ombudsmen would not be comfortable in questioning long-time colleagues, and the job could be perceived by readers as not an independent one.

I came to believe that the discussion of the ombudsmanship model is important, especially since Canada followed a common pattern, and so I shall return to these considerations in the conclusion. Meanwhile, I turn a discussion of why Canadian newspaper ombudsmen have all but disappeared. 


\section{Chapter 5}

\section{THE FALL OF NEWSPAPER OMBUDSMANSHIP}

\section{The reasons for termination}

Canadian newspapers introduced their ombudsmen with fanfare. However, most were quiet when the position was terminated. Only three of the ten papers announced the fact: the Edmonton Journal, Calgary Herald and London Free Press. ${ }^{1}$ The others mentioned nothing, leaving readers to wonder what had happened. There was no accountability in that matter. ${ }^{2}$

But why did newspapers close their ombudsmen's offices? And who was responsible for such decisions? Evidence points to the same people who hired them publishers and executive editors - but others had a hand as well.

It seems cost was the principal factor at four newspapers: the Ottawa Citizen, Montreal Gazette, London Free Press, and Calgary Herald.

William MacPherson retired almost the same day as publisher Clark Davey in December $1992{ }^{3}$ Russ Mills, who replaced Davey, had previously been Citizen

\footnotetext{
${ }^{1}$ The content of those announcements will be discussed and summarized later. Philip McLeod, "Editor's note," London Free Press, Sep. 30, 1995, p. A2; Murdoch Davis, "The Journal pledges to listen directly to the readers; How to call us," Edmonton Journal, Jun. 12, 1993, p. A2; Crosbie Cotton, "Herald bids goodbye to ombudsman," Calgary Herald, Jan. 28, 1996, p. A2.

${ }^{2}$ Overall, ombudsmanship didn't last long. Five of the eleven papers had the position for five years or less: Winnipeg Free Press (four years and a half), Toronto Sun (one year and 2 months), Sudbury Star (roughly four years), Ottawa Citizen (two years and 10 months); and Winnipeg Tribune (five years, terminating with the paper's closure).

${ }^{3}$ MacPherson officially retired January 1,1993, because he had turned 65 . (Liisa Tuominen, Ottawa Citizen librarian, email interview, 9 Mar 2010.) But because of illness, he left the paper the previous month, along with Clark Davey, who says he retired three months earlier than expected: "The Southam Company was looking for a soft landing for Russ Mills who was president of the Southam Newspaper Group but was seeking to return to publishing a newspaper (he had been Ottawa Citizen publisher before me) as a result of a corporate re-organization." (Email interview, $10 \mathrm{Jul}$ 2009.) See also Kathryn May's
} 
publisher. He saw some value in the position, but not enough to justify the expenditure of a senior salary:

I thought it was a useful function, but to some extent it duplicates what press councils do. It was a good vehicle for people who had complaints about newspapers; it was another form of redress. It was hard to justify having a senior person in a role like that. It wasn't contributing directly or more directly to the success of the newspaper. It was hard to pin any actual value to it. It was hard to measure the effectiveness of the position. To be honest, I don't think it made much difference [to readers]. ${ }^{4}$

At the Montreal Gazette, after Robert Walker took a buyout and retired, the position was not replaced. ${ }^{5}$ Michael Goldbloom was then Gazette publisher. He says there were financial pressures to reduce editorial costs:

The decision to close the ombudsman's position came because the opportunity pushed itself to save the cost because Mr. Walker took a buyout as opposed to a conscious decision that this was something that we didn't value. Obviously, it was not something we valued enough to feel that we wanted to continue with the position. If we had been flush with cash, I am sure we would have gone and replaced that person. It was not based on a philosophical belief that the position was no longer useful. ${ }^{6}$

At the London Free Press, Philip McLeod, who was then editor, also cut the position to reduce costs. He says Gordon Sanderson's performance had nothing to do

article: "Southam executive returns to the Citizen; Russell Mills to replace Clark Davey as publisher," Ottawa Citizen, Oct. 29, 1992, p. A2.

${ }^{4}$ Russ Mills, in person interview, 11 Aug 2009.

${ }^{5}$ Robert Walker wrote a farewell column evaluating his six-year tenure as ombudsman, but did not mention the vacancy would not be filled. ("Departing ombudsman thanks readers," Montreal Gazette, May 27, 199, p. B3.) The duties of moderating the corrections fell on managing editor Raymond Brassard, who still holds that position. "Now they [reporters] have to write [the correction] themselves, they also have to send to me the reason why the error was made and that sort of forces them to think about ' 1 should have done...'," explains Brassard. (Telephone interview, 21 Jul 2009.)

${ }^{6}$ Michael Goldbloom, telephone interview, 22 Jul 2009. Robert Brassard, managing editor, adds that in 1996 there was a round of cutbacks achieved through buyouts or voluntary resignations: "At the same that we were eliminating the position we were also reducing the number of editors, proofreaders, reporters, and the content of the newspaper." (Telephone interview, 21 Jul 2009.) 
with the decision, as there were many other cutbacks around the same time - within three years, a reduction to 100 from 160 editorial department employees:

In reality the most important positions in a newspaper are the positions that have to do with gathering the news. Everything after that is an adornment of some kind. When you are going through a downsizing like that, absolutely the only positions that we are really trying hard to protect are the positions which gather news. So in that context the ombudsman's job was seen as being one of secondary importance. It was my decision and I would make it again under the circumstances. The ombudsman's responsibilities returned to the editor-in-chief's office. ${ }^{7}$

At the Calgary Herald, money also seems to be the biggest factor, according to Crosbie Cotton, who was the editor at the time. Cotton said he doesn't recollect much about what happened, although he did remember that he didn't like the position, and is sure he wouldn't have implemented it himself. "I rather invest the money in reporting. I just don't think it is necessary." ${ }^{, 8}$ It is worth noting that when Jim Stott left the post in January 1996, the paper was between publishers. Kevin Peterson had resigned the month before and his successor, Ken King, would assume only in March. Cotton, therefore, held the highest power in the newsroom. ${ }^{9}$

Cotton wrote an article, published the day of Stott's farewell column, explaining the decision to eliminate the ombudsman's position. In it, he reaffirms the Herald's intent to listen and talk to readers and states that the resolution was taken seriously. He also declares that the weaknesses of the position became too evident to the paper:

\footnotetext{
${ }^{7}$ Philip McLeod, telephone interview, 15 Sep 2009. Gordon Sanderson wrote a farewell column and explained that the position was being abolished ("Reader's advocate bids farewell," London Free Press, Sep. 30, 1995, p. A2). In addition, a small note from editor Philip McLeod said the paper would continue to welcome comments and questions from readers ("Editor's note," London Free Press, Sep. 30, 1995, p. A2). ${ }^{8}$ Crosbie Cotton, telephone interview, 28 Sep 2009.

${ }^{9}$ See details in Alan Boras' articles: "Herald publisher resigns," Calgary Herald, Dec. 13, 1995, p. A1; "New Herald publisher appointed," Calgary Herald, Jan. 30, 1996, p. A1; and "Interim Herald publisher named," Calgary Herald, Dec. 20, 1995, p. C1.
} 
Too often, he simply became a buffer between the reader and Herald staff who must be accountable for their decisions. The ombudsman was supposed to be the "court of last resort" where customers turned when they couldn't get satisfaction from those responsible, but increasingly people called him first. We no longer want an extra layer between front-line staff and our customers.

Today, our editors recognize their responsibility to talk with and listen to readers. You can contact any of them during regular business hours, in most cases during the day and early evening, Monday to Friday. ${ }^{10}$

On the other hand, in his last column, Jim Stott evaluates his role in a positive way, saying that it allowed reporters and editors to get a real sense of readers' complaints:

I am leaving the Herald as of now and the ombudsman position is being eliminated. Other channels of communication will be established for readers.

The ombudsman exists as the readers' representative on the inside. As such, the ombudsman is the ham in the sandwich, with readers on one side and staff on the other.

Over the past decade in this seat, I've fielded more than 30,000 calls from readers -- mainly about newspaper content. By answering questions, explaining how things work and unearthing why some things go wrong, I hope I've helped develop a better understanding between journalists and readers. All too often there is no real communication. Those who gather the news and those who read it exist in two solitudes.

It is not an easy balancing act, since complaints about newspaper content are rarely as simple as black and white, or two plus two equals four. More often, they involve moral, ethical or technical issues which defy easy judgments. ${ }^{11}$

\footnotetext{
${ }^{10}$ Crosbie Cotton, "Herald bids good-bye to ombudsman," Calgary Herald, Jan. 28, 1996, p. A2. Cotton wrote that the paper was formalizing a Reader Response Line, to be monitored by Vicki Sand, the former ombudsman's assistant. As of July, 2010, the Reader Response Line is still active, now being called "Reader Feedback Line."

${ }^{11} \mathrm{Jim}$ Stott, "After 30,000 calls and 400 columns -- that's a wrap: Veteran journalist bids adieu after 10 years as ombudsman," Calgary Herald, Jan. 28, 1996, p. A7. Jim Stott didn't explain in his farewell column why he was leaving the paper, and his obituary did not mention it either. (Allan Connery, "Herald scribe kept calm," Calgary Herald, Jun. 9, 2005, p. B13.) According to two interviewees, Crosbie Cotton and Gillian Steward, Stott retired.
} 
That the ombudsman was an unwanted buffer between journalists and readers seems to have played a role in the Herald's decision. It certainly did at the Edmonton Journal. The job there was less valued and even seen as a problem between editors and readers, so was eliminated in 1993, declares Linda Hughes, Edmonton Journal publisher at the time. In this case, she says, there was no cost issue involved. ${ }^{12}$

Hughes states the position wasn't drawing much reader interaction, and therefore the post had become pointless. ${ }^{13}$ John Brown, ombudsman for 15 years, was appointed letters editor, a position that made more valuable use of his time, according to Hughes. ${ }^{14}$ She also says the decision was shared with the editor of the paper at the time, Murdoch Davis, and that the idea may have even been originally prompted by the editorial department because of the buffer issue:

There wasn't very much engagement with readers in that role. It started with really more interest. By the time near the end of the ombudsman's role, we were getting two or three calls a day ${ }^{15}$ on very minor matters, and the ombudsman's column ended up talking often simply about things like grammar. The broader issues of journalism didn't seem to be raised. We just didn't see that it

${ }^{12}$ Hughes decided to abolish the position after a year as publisher. She says there were unspecified issues related to the elimination that she wouldn't speak about: "So that limits somewhat what I might want to say." (Telephone interview, 05 Oct 2009.)

${ }^{13}$ Allan Mayer, who is now editor-in-chief of the paper, confirms that view: "My feeling about the way it was done here is that after a while it wasn't that interesting. There was repetitiveness to a lot of what was being discussed. From a reader perspective, 1 just don't know how much a reader got out of it."

(Telephone interview, 26 Oct 2009.)

${ }^{14}$ Hughes says she thinks the new post made sense to Brown. "I think in fact that he was quite happy in his new role. As I said, we didn't get many calls... in a workplace people talk about things... It was certainly an issue we chatted about often and then it was a fairly consensual decision." (Telephone interview, 05 Oct 2009.) Brown didn't write a farewell column.

${ }^{15}$ Paul Cashman, who was an Edmonton Journal reporter at the time, spent two weeks, sometime in the mid-1980s, as acting ombudsman while Brown was on holidays. He confirms that the number of phone calls was low: "They [newspaper managers] said that I just had to deal with readers, making sure the memos got sent as required. I only really remember a call... and that was it for the two weeks. After I read Times and Newsweek and the newspapers... it was pretty dull, there was nothing to do. People were not phoning or sending letters. I don't know what the regular tale of work was, but during that period was really quiet. It was the most boring two weeks I have ever had." Cashman doesn't recollect sharing this with any senior person in the newsroom at the time. (Telephone interview, 05 Nov 2009.) 
was performing a valuable service. The second reason was that editors felt, and I think quite rightly, that they didn't want a barrier between them and the public. When we first started the position, there was a certain sense from the editors that "that is great, we don't have to talk with people who call us with complaints". But they realized over time that in fact they wanted to talk to the public - that, as editors, they felt engaging with the public on stories and issues at the time was in fact what they should be doing and it was actually helpful in the whole process. So they didn't want someone between them and the readers. 16

Murdoch Davis, the editor just mentioned, is now executive editor at the Toronto Star. He was reluctant to give his thoughts because, he said, they could be seen as if he were speaking on behalf of his current office. He, however, said he would agree with Hughes' description of the facts. "Linda was always great to work for, and disarmingly charming. If that's how she describes the events, I will agree," he says. ${ }^{17}$

In 1993, Davis wrote an article explaining why the position was being terminated and the paper's new "approach" to listening to readers, which included a Reader Response Line, the same procedure taken at the Calgary Herald:

As part of this new approach, Publisher Linda Hughes is eliminating the position of Ombudsman. John Brown returns to the newsroom. He will be closely involved in our new approach. His new position is Reader Response editor. ${ }^{18}$

\footnotetext{
${ }^{16}$ Linda Hughes, telephone interview, 05 Oct 2009.

${ }^{17}$ Murdoch Davis, email interview, 16 Oct 2009. In addition, Bill Newbigging, who was Edmonton Journal publisher before Hughes and an advocate for the ombudsman position, states that Hughes' assessment was probably made at the right time: "There is a time for everything. Some things just run out of steam and out of the time and readership surveys show that they are being read or not. And editors have to make choices on that basis. And for my money, Linda and her crew always made good choices. So 1 think it was probably a sensible one for the time. They wouldn't have done it capriciously." (Telephone interview, 9 Nov 2009.)

${ }^{18}$ Here it is worth pointing out that the Globe and Mail today has a Reader Response Editor to link readers and the corporation and act as the paper's advocate. According to the paper's Editorial Code of Conducts, "The reader response editor responds to reader comments and complaints as a knowledgeable and trustworthy source and an advocate for the newspaper, and also manages editorial responses to ethical dilemmas and breaking controversies involving The Globe's journalistic credibility. The reader response editor handles requests for corrections, alerts staff that an error has been made, works out wording for corrections, arranges for publication of corrections and monitors the number and type of errors that are
} 
John has served ably as Ombudsman for 15 years. He brings his experience helping readers to our new commitment. As Reader Response editor, he will edit our letters page. He'll also staff the Reader Response line. ${ }^{19}$

We included the letters role because letters have traditionally been part of readers' response to the content of their paper. Ending the Ombudsman job was a difficult decision. Many readers have appreciated having someone available when front-line editors were too busy. We are committed to maintaining that availability.

After much thought, the publisher and I concluded that one of the strengths of the Ombudsman job is also a great weakness. An ombudsman is independent.

On the plus side, that means he isn't subject to direction from me or anyone responsible for content. He can't be turned into an apologist for the newsroom. On the other hand, he is unable to take action on a complaint or comment. He can't decide to run a correction. He can't direct that a story be done. He has no authority over the paper's staff. Department editors view ombudsmen as being outside the editing process.

Perhaps the most serious weakness of the position is that it can be a buffer [between] us. Such positions are supposed to be a "court of last resort." They are meant as a place to turn if you don't get satisfaction from those responsible.

Increasingly, though, people call the ombudsman first. That puts an extra layer between front-line staff and our customers. At a paper with senior managers and editors dedicated to serving readers, we don't want that. ${ }^{20}$

It must be mentioned that during my research the word "buffer" was used a few times in a positive way, contrasting with the meaning implied by the Journal and Herald staff above. Two Star executives, editorial page editor Ian Urquhart and communications

published. The reader response editor also co-ordinates outreach campaigns and serves as the early warning system for journalistic errors and attacks on the newspaper's integrity." Gerald Owen, who holds the position, says that not all reader complaints are taken to him, and the post takes only $20 \%$ of his time; he also writes editorials, and edits the Saturday Globe Essay. The position is not publicized by the newspaper, or its website; and Owen doesn't write columns: "I must say that I am glad that I don't have any column on this matter. I don't really want to be sort of publishing things that are critical of my colleagues. I might actually think that my colleagues' performances haven't been defective. l'd really rather be responding directly to people who are actually complaining, than getting into a position of sort of playing by sides," he adds. (Telephone interviews, 10 and 24 Sep 2009.)

${ }^{19}$ The Reader Response Line is still active at the paper (as of July, 2010).

${ }^{20}$ Murdoch Davis, "The Journal pledges to listen directly to the readers; How to call us," Edmonton Journal, Jun. 12, 1993, p. A2. 
editor Bob Hepburn, for example, used the term when describing the usefulness of an ombudsman. "Certainly readers have somebody to go to [complain], and for the journalists and columnists it provides a second layer basically. They don't need to deal directly with a complaining reader. It's a buffer," Urquhart summarizes. ${ }^{21}$ Indirectly, Star reporter Denise Balkissoon suggests the same: "It's definitely helpful having Kathy and her assistant, Liz, on staff. Not only to remind me to check and check again, but to mediate when readers become unhappy with a story."22

In the Sun's case, the motives for the termination seemed to be mixed - both financial and non-financial in nature. The paper experienced a series of layoffs. Editor-inchief Jim Jennings resigned in September 2006 and the readership editor's position ended a few months later. ${ }^{23}$ The paper's interim head, Glenn Garnett, who was executive editorin-chief for the Sun Media Corporation, chose not to continue with the position in the midst of downsizing:

As newspaper organizations, we all have to make some very difficult choices about staff sizes and we lost a lot of good people reporters, editors, photographers - and it was decided that that position was one that we could return to what we have been doing with readers' complaints and inquiries for years. Down the list, we decided that that position, which only had been in course for one year, was one which we could compensate for. That is the reason why we made that decision. It was not focused on that [position] alone, it was among many other difficult decisions we had to make. $^{24}$

\footnotetext{
${ }^{21}$ Ian Urquhart and Bob Hepburn, in person interviews, 16 Jun 2009. The word buffer was also cited as a good thing by William MacPherson in his column "Ombudsman's role a buffer against injustice." (Ottawa Citizen, Mar. 10, 1990, p. B3.)

${ }_{22}^{22}$ Denise Balkissoon, email interview, 16 Aug 2010.

${ }^{23}$ "Sun's news boss resigns post," Toronto Sun, Sep. 21, 2006, p. 6.

${ }^{24}$ Glenn Garnett, telephone interview, 14 Aug 2009.
} 
But the problem was also a matter of philosophy. As Alison Downie suggests,

Pierre Karl Péladeau, president of Quebecor, which owns the Sun Media chain, didn't see the desirability of an in-house critic:

Quebecor started to get more involved in the daily operation of the newspaper. Jim was pretty much forced to resign; they didn't like the direction Jim was taking the paper. After Jim left, I was not being told as much what I should write about, but they certainly suggested to me that some things were off limit. It was also expressed to me that Quebecor - Pierre Karl [Péladeau] - could not understand why a newspaper would pay someone to criticize their own newspaper. I was told that the position was being made redundant and I would be given a new role, which didn't happen. I was let go. In September $2006 \mathrm{Jim}$ resigned. We had no editor in chief. I had no boss. I continued doing what I was doing, probably for a couple of months. By October, or November in 2006, there was no position anymore. I used to write a weekly column. And they stopped the column. But I was still addressing some readership complaints, but I was not writing my weekly column. They never announced to the public that they did away with the position. Technically I still had the title, but I was not doing the job. I was still filling in for other editors and stuff like that. So the job became very difficult, it was not reader focused anymore. I was offered a position that I didn't want, and when I said that I was let go. That was on January 6,2007 , my last day at the paper. ${ }^{25}$

Downie's last column was published November $5,2006 .{ }^{26}$ She says that her column just disappeared; she was not even allowed to write goodbye. ${ }^{27}$

After Halifax Chronicle Herald's only ombudsman, Roger Edge, retired, the vacancy was not filled. Terry O'Neil, the general manager at the time, states that the

\footnotetext{
${ }^{25}$ Alison Downie, telephone interview, 24 Jul 2009.

${ }^{26}$ Alison Downie, "Public life can be such a b...," Toronto Sun, Nov. 5, 2006. The column was about newspaper coverage of Belinda Stronach's personal life and Norman Spector's firing after calling Stronach a "bitch" on a Vancouver radio show.

${ }^{27}$ Downie was questioned by bloggers about what happened to her role: "I was in an awkward position because when they [bloggers] phoned me and asked me for a quote, and I couldn't really comment because of course I didn't want to lose my career. I needed the job." (Telephone interview, $24 \mathrm{Jul} 2009$. ) Glenn Garnett acknowledges that there was no announcement that the position was abolished, and that the paper [he said "we"] didn't see much value on the readership editor's column. "We didn't set out to come up with something comfortable," he adds. (Telephone interview, 14 Aug 2009.)
} 
decision wasn't based on economic reasons, but simply because there was a consensus

that the role could be handled by management:

It just wasn't the same sort of need anymore. Before Roger retired, the need was lessened. [The paper] was getting less and less complaints and then, when he retired, it was a natural flow of events that [the position] would not have to be fulfilled again. Had he not retired, he would have maintained that position. ${ }^{28}$

At the Sudbury Star the position just faded away as the duties were taken from the editor of the editorial pages. Chris Krejlgaard, Sudbury's last ombudsman, states there was no alteration in his salary and he continued as editorial page editor for six more years. "We had a new managing editor [Roger Cazabon] who saw no value in that position. And basically any complaints he would deal with," Krejlgaard reports. Cazabon, on the other hand, said his recollection is that the position was eliminated just prior to his appointment as managing editor. "I may be wrong on that count, but as you can see, I just don't recall what transpired. ${ }^{29}$ The exact date of termination is uncertain. ${ }^{30}$

What is clear is that Krejlgaard dealt with only a few complaints as ombudsman, especially at the end: one or two a week.

Basically that was pretty much what I dealt with, those couple. There were weeks where I got none. Sometimes there would be letters and notes mailed to me. I was not too surprised [about the low number of complaints]. There could be other editors getting phone calls in their section that I wouldn't be aware of. Nothing

\footnotetext{
${ }^{28}$ Terry O'Neil, telephone interview, 30 Nov 2009. Roger Edge confirmed that communication with readers became less frequent. (Telephone interview, 09 Nov 2009.)

${ }^{29}$ Roger Cazabon, email interview, 06 Nov 2009. Don MacDonald, a long time reporter for the Sudbury Star and city editor for the past nine years, also confirms that Cazabon was managing editor at the time of the position's abolition. (Telephone interview, 09 Nov 2009.)

${ }^{30}$ The last column by Chris Krejlgaard found was on May 20, 1994 (my research for Krejlgaard's columns went until September 23, 1994). However, according to Krejlgaard's recollection, the position was abolished without notice to its readers sometime late in 1994 or early 1995.
} 
really changed except that I didn't have to do [the ombudsman's tasks] anymore. ${ }^{31}$

When the Winnipeg Tribune folded in 1980, there wasn't any comment regarding locals losing a reader's advocate. That wasn't the case at the Winnipeg Free Press. When the position was abolished there, the issue was discussed in several newspapers, including in a couple of ombudsmen's columns, and on radio talk-shows. ${ }^{32}$ The situation was delicate. In a nutshell, following controversy over a particular column, the ombudsman resigned. Versions of what happened differ between publisher Maurice Switzer and ombudsman Barry Mullin, with a third version coming from Dave Lee, managing editor at the time.

Switzer came to the Free Press in March, 1992, from the Sudbury Star, where he had also been publisher. The Free Press was in financial difficulty. According to him, it went from a $\$ 25$-million a year profit to a loss. He also says he encountered other problems, such as a lack of job descriptions for editorial positions. He recalls great resistance from the editorial staff in making changes, especially ones related to news judgement. ${ }^{33}$ He was under pressure to do his work right, he says.

\footnotetext{
${ }^{31}$ Chris Krejlgaard, telephone interview, 28 Oct 2009.

${ }^{32}$ Maurice Switzer and Steve Pona, now Winnipeg Free Press business editor but on city desk at the time, recollect debates about the case on radio talk-shows. Examples of newspapers' articles/columns that made reference to Mullin's case include: Chris Cobb, "Media; Winnipeg Free Press fires ombudsman," Ottawa Citizen, May 6, 1992, p. A5; "Winnipeg Free Press; Association criticizes ombudsman restrictions," Ottawa Citizen, May 14, 1992, p. A7; "Handling of ombudsman by paper draws criticism," Toronto Star, May 14, 1992, p. A14; David Roberts, "Winnipeg departure of newsman puts paper in spotlight," Globe and Mail, May 7, 1992, p. A6; Chris Cobb, "Ombudsman fired for L.A. riot column," Vancouver Sun, May 6, 1992, p. A4; William MacPherson, "Newspaper ombudsmen: they lead a lonely, arm's-length existence," Ottawa Citizen, June 20, 1992, p. A13; and Don Sellar, "Another one bites the dust," Toronto Star, Feb. 24, 1996, p. B2.

${ }^{33}$ Switzer adds: "[When] you are used to work in small operations, you are used to being involved [in everything]. I still believed that I was responsible for the news content of my newspaper. As long as I was the person signing the checks, I was responsible for the product, for all of the operations. I came in to that environment as the outsider. I would hear, 'Oh he just worked for little papers,' etc... But that was fine.
} 
Then on May 1, he read a Mullin column that really upset him. The column was about the fact that the Free Press "missed" the importance of racially motivated riots that occurred the previous night in Los Angeles. The paper had placed the event on the back page of its first edition (though it changed placement in its second). That morning, Mullin was called into the publisher's office. Managing editor Dave Lee was already there.

"The publisher went over the column and expressed his displeasure and Mr. Lee took notes," explains Mullin. "So the publisher basically laid down a series of conditions that substantially altered my employment." The conditions were: his columns would from then on be edited by Lee; he would have to submit his columns two days in advance of publication; and he would have to apologize in his next column for making an error in judgement.

[Switzer] didn't tell me I was fired. He just laid down the conditions and said it was up to me to decide whether I can abide by those conditions. So basically at that point I was dismissed from his office and I went through the editorial department and I spoke briefly with John Dafoe [the editor]. I told John that I had written my last column for the Free Press. Then I went in to the managing editor's office and said to Mr. Lee, "Would you run those conditions by me again?" and Lee gave me the conditions that he had written down in the meeting with Mr. Switzer. I went back to my office and I wrote my resignation. I cleaned [out] my desk and handed it [the resignation letter] in to Mr. Lee. I left the building and never went back. When people found that I had resigned and the reason I had resigned, some of my friends called and said, "You didn't resign, you were constructively dismissed. Contact

You have to have some kind of skin when you go to that kind of environment when you are a new person. I had discussions with the editors about things I liked and didn't like. I had expressed the concern, as a lot of publishers and editors had, that a newspaper dwelt on the negative. I believe if you focus on well written articles, good stories, let the readers make up their own minds - that is what will make your newspaper profitable and respected. If you look at journalism text books, they teach to look for conflicts. That may be valid. But if you are deciding to put out a newspaper, and if your newspaper is not successful, as ours was not, maybe you are not doing something right." (Telephone interview, 19 Oct 2009.) Dave Lee has another version for the news judgement conflicts: "[Switzer] would talk about a local carpet store having a big carpet sale as being a news story. Well, when you are in a big city, I am sorry, that is not what exactly what we call hot news." (Telephone interview, 29 Oct 2009.) 
this lawyer [Robert Tapper] because that is what is taking place." I contacted Mr. Tapper who took my case and proceeded to sue the Free Press. The case was settled out of court in $1996{ }^{34}$

On the other hand, Switzer emphasizes it was not in his intent to deal with or cut positions in specific editorial departments.

My job was to try to make the newspaper financially successful without diminishing the quality of the product. As an editorial background person, the last thing I wanted to do was to start chopping quality of the product. So here I am spending all my time going back and forth to our Toronto head office trying to accomplish this, and I see a piece by one of my own employees, whose job I am trying to save, that accuses news management of making "puffy" journalism. I was absolutely dumbfounded. Mr. Mullin, who was supposed to be a model of journalism practice, never sought to seek my opinion before his column was printed and never sought to speak to the editor involved. He just did all this on his own, and again that to me was not good journalism, so I asked to see him and called him in my office and was pretty upset. I have never been in a situation where anybody sort of criticizes their own publication without getting the facts, a thing that we expect our competitors to do. But he had not practiced good journalism by getting both sides of a story and he made us look bad. He was criticized not for what he wrote, but because he didn't even speak to the people who he was writing about to verify or modify his assessment of what happened. He did not seem to be answerable to anybody within the organization. I was dumbfounded to see that he felt that he was not subject to the basic rules of journalism or that he was not accountable to anybody. The people were not paying his salary. The Winnipeg Free Press was. And his article didn't reflect the views of any readers that I know of. It was his personal opinions. I said: "Well, listen, in the future I want to see copies of your articles before they are submitted for print as I do editorials." 35

Two points need to be explained. First, Mullin says his office received lots of complaints about the play of the riot story and that was mentioned in the column; however, he didn't cite any comments from anyone inside the newspaper. Second, in the

\footnotetext{
${ }^{34}$ Barry Mullin, telephone interview, 17 Oct 2009.

${ }^{35}$ Maurice Switzer, telephone interview, 19 Oct 2009.
} 
column, Mullin uses the Los Angeles riots as an example of recent changes at the paper

in the balance between hard and soft news. What Mullin didn't know is that the soft front page story that ran May 1 was a placement request from Switzer. ${ }^{36}$

Was it a bad career move? According to Lee, yes. ${ }^{37}$ He didn't agree with the way

Mullin criticized the Los Angeles coverage, but neither did he agree with the new

conditions imposed by Switzer:

When [Mullin] wrote the column, he didn't take the time to find out why the story hadn't been placed the place it was, and that to me and to a lot of people was simply irresponsible. Barry had a very good career as a writer, but he never made up a newspaper and anybody who put a newspaper at a deadline is forced to grapple with a lot of things including late stories. The L.A. riot was a huge story. Nobody questions that, but the significance of it - I don't think it was really known that evening when the paper was being putting together. Therefore, the story was rightly or wrongly put on the back of the paper. And as I recall correctly, the column made some reference to some - what he called "puffy" - piece that ran on the front page. That was a bad choice of words because that "puffy piece" was something that the publisher had asked to be on the front page. [On the other hand] I definitely felt it was not right [the conditions imposed]. I thought it was a conflict of interest. How can you have someone to vet a column that is being written about the work that you or your department has done? It was an outrageous suggestion. $^{38}$

Moreover, Lee acknowledges that Switzer was under a great deal of pressure, but also believes there was a "clash of personalities." He thinks Mullin would not have

\footnotetext{
${ }^{36}$ Barry Mullin, "Some subscribers missed front-page L.A. riot story," Winnipeg Free Press, May 1, 1992, p. 7. It must be pointed out that the news judgement problem that Mullin perceived actually started the previous fall, preceding Switzer's arrival. "Since the paper underwent a facelift last fall, it also began to turn away from harder news stories to softer items. That shift followed a reader's survey which indicated that some readers want soft news, more news features, no turn and an easier-to-read product," Mullin wrote.

${ }^{37}$ Lee adds: "In retrospect, one of my greatest regrets was that it [the situation] brought to an end Barry Mullin's career as a newspaper person. That was too bad because I didn't think he deserved that treatment. I think he got a raw deal." (Telephone interview, 29 Oct 2009.)

${ }^{38}$ Dave Lee, telephone interview, 29 Oct 2009.
} 
continued in the position even if the L.A. riots episode hadn't happened. He says Switzer didn't like Mullin and thought the position was a waste of money, two comments he drew from conversations with the publisher: ${ }^{39}$

I think he was a marked man before that. It came up away before the L.A. story. [Switzer] had complained to me about Mullin's columns long before the L.A. riots. I think the L.A. riots column was the final "straw". ${ }^{40} \mathrm{He}$ simply thought they were dealing with very "paddy" issues. Let's face it, often they were. To some degree it was an understandable criticism. And yet you either believe in it [the position] or you don't. And if you don't, it doesn't make any difference what you write about or how good the job that person does. It's just not going to work. ${ }^{41}$

In addition, Lee affirms that the appointment of Mullin as ombudsman caused a

huge impact on the newsroom, especially among editors:

As a matter of fact, when the newsroom found out that I had recommended Mullin it was sort of uproar of many of my colleagues in the newsroom who were quite adamant that he [Mullin] was incapable of judging their efforts. Mullin's first years writing about readers caused a steady stream of complaints from reporters and editors. For a long time I found myself constantly arguing that he was only doing his job. Unfortunately, Barry continued to create this growing core of complaints to me and the publisher. They [journalists] truly believed that he always sided with readers' complaints regardless the importance or circumstances. Unfortunately on the personal level, I believe, he was also settling some old scores with the newsroom. He had been the city editor and had been demoted and when that happens [there are] hard feelings... naturally he blamed certain people... This was not [the reaction] from everybody, but it was certainly from the senior positions. I don't think it was so much the position itself that my staff at that time opposed. I truly believed it was more the

\footnotetext{
${ }^{39}$ Switzer, on the other hand, says that Lee told him that Mullin was not "regarded among his colleagues and the job was sort of created as a soft landing for him." (Telephone interview, 19 Oct 2009)

${ }^{40}$ Switzer says the riots column was the first time that Mullin's column really came to his attention.

${ }^{41}$ Dave Lee, telephone interview, 29 Oct 2009.
} 
individual who was appointed. I think it was more a personality issue and that is unfortunate. ${ }^{42}$

The case is complex. ${ }^{43}$ Lee didn't know that Switzer was familiar with ombudsmen, let alone that he had implemented the position at the Sudbury Star. ${ }^{44}$ However, it is also true that Switzer's point of view on ombudsmanship doesn't include press criticism:

I regard [the position] as the way for readers to express concerns not for the individual [the ombudsman] to express their personal concerns, but what [the readers] didn't like about the newspaper. For me, the ombudsman was a way to fill, in a public way, readers' complaints and I don't think the concept was ever intended for one person to set themselves up as some sort of critic of their own publication. One of the things that I started to see [at the Sudbury Star] was the individual starting to make his personal comments on what he didn't like about reporting instead of acting as a representative of readers. There was an element of independency there. In any event, I did have that experience and it was important to have someone to represent the reader's interests. ${ }^{45}$

It seems, then, that the end of ombudsmanship was tied to the circumstances that each newspaper was going through at the time: budgetary problems, culture of the newsroom, readership engagement with the position and, most importantly, the appreciation that top executives had of the job, including their evaluation of ombudsmanship as a "buffer" between readers and newsroom.

${ }^{42}$ Dave Lee, telephone interview, 29 Oct 2009.

${ }^{43}$ Bruce Rudd, who was publisher between Arthur Wood and Maurice Switzer, didn't change any aspect of Mullin's role as ombudsman, according to both Mullin and Lee. Rudd is deceased.

${ }^{44}$ Lee later filed a wrongful dismissal suit against the Free Press. A settlement was negotiated.

${ }^{45}$ Maurice Switzer, telephone interview, 19 Oct 2009. It is worth pointing out that Don MacDonald, who was working as the Sudbury Star wire editor when Roger Worth was appointed, affirms that the lack of independence of the role was perceived as a weakness. "My recollection is the person doing the job didn't really have the independency to do that, and to me that is critical in that kind of position. If a senior manager was being criticized [by the readers]; he [the ombudsman] would rarely do so in his reports. I think the position was always compromised in my view, and it was not as effective as could have been. It was still useful because they [the ombudsmen] would review things. It made people more aware that they should think about what they were doing," MacDonald says. (Telephone interview, 09 Nov 2009.) 
Newspapers were not willing to comment in print on the termination of the position. But neither was there any reported outrage by any newspaper audience demanding the return of its ombudsman. Yet, the importance the public put on the position remains unknown.

Bill Newbigging, former publisher at the Edmonton Journal, reflects on that. For him, the community, whose complaints were adjudicated by ombudsmen, probably appreciated the position. After all, why would they oppose something that benefited them? "It served a function and it served it well at the time," he says. "Its long-term value, however, could be indicated by the fact that it doesn't exist except in one Canadian newspaper now." ${ }^{46}$

\section{Toronto Star ombudsmanship not immune to problems}

The Toronto Star has had nine incumbents so far. The paper, it seems, carries a strong culture of ombudsmanship: at more than 38 years, it is the longest running in the country. Editors and former editors interviewed were generally receptive to the position and to working with the ombudsmen. ${ }^{47}$ However, there are indications that the post at the Star is not immune to problems or conflicts.

\section{Interruptions in incumbency}

There have been times in which the position has been vacant. When Don Sellar left the job for a sabbatical year in August 2000, there was a competition to fill the vacancy. Eventually, Robin Harvey was chosen, but did not start for three months - in

\footnotetext{
${ }^{46}$ Bill Newbigging, telephone interview, 09 Nov 2009.

${ }^{47}$ This statement is based on interviews with Bob Hepburn, Star communications editor; Fred Kuntz and Giles Gherson, former editors-in-chief; lan Urquhart, editorial page editor; Mary Deanne Shears, former managing editor; and Michael Cooke, editor-in-chief.
} 
December 2000. When Sellar left for the second time, taking a buyout, it was January 2005; Sharon Burnside, who followed him in the job, did not start until March. Then, when Burnside was asked to return to work in newsroom training and development in December 2006, Kathy English won a competition as replacement and started in May, 2007, five months later. Phone calls and corrections during those gaps were handled by the ombudsman's assistant.

However, the gaps between incumbents are insignificant compared to the times when the job or the person holding it was severely challenged by superiors. It seems that was the case during both Sharon Burnside's and Robin Harvey's tenure.

\section{Conflicts}

Star former editor-in-chief Fred Kuntz affirms that, when Burnside was public editor under publisher Jagoda Pike, the ombudsman office experienced a difficult time:

I don't know if Sharon Burnside had the weight and the authority within the newsroom. She is a very good person, very kind and fair, but people have different strengths that suit them to different areas of the business. Sharon was always a very good mentor to interns. I hired her originally into the Star for that position. But, you know, the ombud is a tricky position because you have to respond to the public, you answer to the publisher and you have to question the editor-in-chief. You have to fiercely, courageously question what is going on, but do it in a very political and balanced way. And I don't know if she had all of that. She answered to the publisher who is Jagoda Pike [at that time] and it's hard to think of people who have a more different sort of personal orientation than Pike and Burnside. Both are tremendously capable women, big brains and good intentions, but have different styles. And the style of the ombudsman and the style of the publisher have to match. ${ }^{48}$

Giles Gherson was Toronto Star editor-in-chief from 2004 to 2006. He agrees that the position needs chemistry between the incumbent and publisher to work:

\footnotetext{
${ }^{48}$ Fred Kuntz, telephone interview, 22 Oct 2009.
} 
If the publisher doesn't have an interest in it or doesn't feel it is very important and doesn't want to be bothered with those kind of things or wants to find someone weak, then they can do that. But of course it's going to lose all of its value. It is only as good as the group that installs the ombudsman, how they treat the ombudsman and the ombudsman itself. ${ }^{49}$

Burnside worked, in fact, for two publishers: Michael Goldbloom, who appointed her, and his successor, Pike. ${ }^{50}$ Asked if she had problems with the publishers she worked for, Burnside replied:

I would say absolutely nothing with Michael. He had a great picture view of the role of the ombudsman. And we always had great conversations [about various cases]. And I would say that with Jagoda was a bit different. There were no confrontations. I would say we had huge general chats about things like, if the readers were upset about basically anything connected to the paper, I thought it was my job was to speak for the readers. The dynamics of the job make these tensions. We expect to work through [those kind of conversations] taking a job like that. ${ }^{51}$

In January 2007, Burnside was asked to return to newsroom training and development, where she worked before the ombudsman appointment. The request came from both the editor, Giles Gherson, and publisher Pike. Says Burnside:

There were some things they wanted to accomplish in the paper and in the newsroom and they thought, because of my training background, that I could [help in the accomplishments]. At the time I probably said to the publisher that I was enjoying the job [as public editor]. It probably takes a year to sort of get the pace of it [the job], understand the pressures, and after a couple of years, you just start to feel sort of okay. I think I would be happier to stay in

\footnotetext{
${ }^{49}$ Giles Gherson, telephone interview, 05 Nov 2009.

${ }^{50}$ Goldbloom was the Star's deputy publisher in 2003, and publisher from 2004 to 2006 . Pike was publisher from 2006 to 2008.

${ }^{51}$ Sharon Burnside, telephone interview, 25 Jun 2009.
} 
the position. But at that time, the training was a priority for them. So they asked if I would do that and I said 'sure.'52

At that time, former ombudsman Don Sellar was officially retired, but he maintained contact with a couple of friends at the paper. According to him, the problem was with Pike's ideas of ombudsmanship. “The Star's tradition has been very strong with one exception: Jagoda Pike. Numerous editorial informants told me Jagoda Pike did not brook criticism of the newspaper by the ombud," Sellar affirms. ${ }^{53}$ Jagoda Pike was contacted by email and by phone through her secretary, but chose not to be interviewed.

Robin Harvey didn't have the most pleasant of experiences. She was the first female ombudsman at the Star and the one whose tenure was shortest: ten months. It will be recalled that she won a competition to replace Don Sellar when he left for a sabbatical year (Sellar was supposed to return in a different capacity). ${ }^{54}$ Harvey started the job in December 2000. And so did her "problems." She had a disagreement with the managing editor, Mary Deanne Shears, about a column she wrote - her third. ${ }^{55}$ It was about a reporting procedure Harvey felt was not ethical journalism. The story involved a person selling illegal goat meat, which Harvey calls "an excellent piece of journalism." The reporters, working undercover, got the seller to deny the fact. But, Harvey says:

They got him on tape, but they didn't make the attempt to go back with the video and say, 'Hello, we are the Toronto Star. We have done this and now what is your comment?', and to me this is a

\footnotetext{
52 Sharon Burnside, telephone interview, 25 Jun 2009.

${ }^{53}$ Don Sellar, telephone interview, 22 Jun 2009; email interviews, 9 Mar and 13 Apr 2010.

${ }^{54}$ Sellar had stayed at the job for eight years when he signed up for the sabbatical year: "I thought that it was time for someone else to do it. I enjoyed my job, but I was thinking 'How do you leave this job in a grateful way?', so the sabbatical seemed to be a nice way to do it. I took my year off and about a month before I got back, John Honderich, who was by then the publisher of the paper, phoned me at home and said 'Would you like your old job?' and I said 'sure, why not?' and then I went back for another three years." (Telephone interview, 22 Jun 2009.)

${ }_{55}$ Robin Harvey, "Slaughterhouse operator deserved his say," Toronto Star, Dec. 23, 2000, p. 6.
} 
major broken journalism rule. Initially I was very strong about it. I went to all the people [related to the story] to get different points of view. She [Shears] was the main person who was going to comment. She said, 'We didn't [go back] because we felt if you go back to him he would close down shop immediately and public health would not have time to come in and get him, and my response was, 'Well, we are not the police. We are journalists.' The first column I wrote was fairly worded more strongly. It didn't go out because my policy was always to take the column to the managing editor and then the publisher would see it. She was furious and went to him [the publisher]. He said: 'You two work it out.' So I sat with her and we went over it and he said that ultimately it was still my call. A different version of it came out, but with the same points. From then everything went downhill. ${ }^{56}$

This column was the first of many "conflicts" that she would face on the job, not only with Shears but also, and more importantly, with publisher John Honderich.

According to Harvey, the disagreements added up. For example, the number of editorial corrections she published was higher than other ombudsmen had done. But the problem, according to her, was that the paper was switching to a new computer system, which led to more errors not being caught by editors. A second issue was related to Star coverage of the Intifada (Palestinian uprising in 2000).

I compared the Star coverage to the Globe's and to the Post's and other American papers plus several other newspapers and analysed the language... I came up with a thing this big [showing with her hand] and I didn't say we [the Star coverage] were pro-Palestine and anti-Israel, but I did point out that in my opinion there were some things that were more aligned with the European papers, which were considered to be more pro-Palestinian papers. I was just trying to point that out. I felt that the publisher was not happy with that. After reading it [the report], he dropped it into the garbage. It was three months in analysis of the papers ... and I had asked him [if I could do the analysis]. ${ }^{57}$

${ }^{56}$ Robin Harvey, in person interview, 15 Oct 2009.

${ }^{57}$ Robin Harvey, in person interview, 15 Oct 2009. 
In a third confrontation, Harvey wrote an erroneous correction and apologized for it in a column. It was about a Star book review, which included a reference to a horror film. She received a complaint claiming a factual error. She was "familiar" with the film and thought the reviewer had indeed made an error. She couldn't reach him and wrote a correction on her own. In fact, the reviewer was right. Within three days, she was called by publisher Honderich, who had her apology column in hand. ${ }^{58}$ As Harvey recalls it:

He said; 'What is this? The ombudsman is not supposed to make mistakes! And look at all your corrections. I notice that your corrections is triple the corrections that happened before.' Then he added: 'I am temporarily stripping you of authority and anything you write or do has to be vetted by Carol Goar [the editorial board editor]. ${ }^{, 59}$

The vetting went on for four or six weeks. ${ }^{60}$

She went home that night and called Burt Bruiser, the Star lawyer. She asked him if she should quit, but was advised to wait and see what would happen. "Carol was really sweet. She basically let me do whatever I was going to do. She looked at them [columns] and would say this is fine," Harvey adds. Honderich, afterwards, lifted his restriction. But, somehow Harvey sensed that in general the publisher was not happy with her work; and, at the same time, things were getting tense with managing editor Shears as well.

\footnotetext{
${ }^{58}$ Robin Harvey, "Correcting the corrections," Toronto Star, Apr. 7, 2001, p. K6.

${ }^{59}$ Robin Harvey, in person interview, 15 Oct 2009.

${ }^{60}$ In an email interview, March 26, 2010, Carol Goar writes: “I'm afraid I don't recall the details clearly. Officially, as you probably know, the ombudsman reports directly to the publisher, so I was reluctant to intervene. But when John explicitly asked me to review Robin's columns, I agreed. My recollection is that the arrangement didn't last long. Her predecessor, Don Sellar, who'd done the job for eight years, was a very senior journalist, who'd worked on Parliament Hill, been a foreign correspondent and served as interim editorial page editor. His news instincts were excellent and he understood the internal dynamics of the Star. His columns seldom, if ever, caused the publisher any trouble. He had a soothing personality and an ability to defuse contentious issues. Robin was more of a crusader. She'd take risks. She'd wade into extremely sensitive areas such as Middle Eastern politics and racial profiling. At times, she didn't have a full understanding of the complexities of these issues."
} 
The combination of all these factors made Harvey believe there was an insufficiently supportive climate to justify continuing at the job. "At that point I thought I don't want it [to keep on the job]." Harvey didn't write a farewell column. "I decided that was inappropriate under the circumstances," she explains. Harvey stayed until Don Sellar came back from his sabbatical year. ${ }^{61}$

Shears, for her part, says she holds the ombudsman's position in high regard. ${ }^{62}$

She affirms she occasionally faced disagreements over corrections or the substance of columns, but with other ombudsmen as well, not just Harvey. The differences were something customary and part of the business:

We disagreed on some things for sure, but those are professional disagreements. I tried never to cross the line into anything personal. I think it is a position that one grows into, the ombudsman's position. You are an editor, you are working at the newsroom one day and the next day you are in a very different position. The ombud, I think, it takes a time to adjust to, and in a way it is a lonely position. You are now judging your peers, whereas you were working with them. So I think it takes awhile to get used to that different work and environment, but I don't think I put any pressure on her [Harvey]. We disagreed over some things, and agreed on others. That is the nature of the game. ${ }^{63}$

${ }^{61}$ Robin Harvey, in person interview, 15 Oct 2009. Harvey accepted an invitation from John Ferguson, then assistant city editor, to write "Consumer Watch," a column that resolved consumers' problems. It ran for a year and a half. After that, she returned to reporting. Harvey took a buyout in 2007 and left the paper to become a freelance writer and photographer.

${ }_{62}$ In her interview (08 Feb 2010), Shears also declared: "As I got into more senior positions, I really came to understand the position even more and to appreciate that it was pretty important for the Star to have this and to invest in that way. I think it is very important for readers and viewers even at the Web to have somebody to talk to at the same time. I also feel that with the internet that it is very important for somebody to be able to sort out any kind of charges or allegations or feelings of unfairness that are said about newspapers. I think it is important for reporters to work to very high standards, and I think an ombudsman helps that. I also think this is important to have an ombudsman to explain the paper's position on many things, such as conflict of interest, freelance, all those kind of things. It helps to explain the values of the individual of the media company to people who don't know." Shears worked at the Star for 35 years.

${ }^{63}$ Mary Deanne Shears, telephone interview, 08 Feb 2010. 
Honderich recalls that there were some problems indeed at Harvey's tenure as ombudsman: "I do recall in vague terms this incident [the vetting of her columns] and issues we had with Robin Harvey as Ombud. But I cannot recall the specifics," he states in an email. ${ }^{64}$

Don Sellar worked with Honderich as publisher for most of his years as ombudsman ${ }^{65}$ and says he never had interference from Honderich or the other two publishers under whom he worked:

I think it's crucial to have the publisher being on side. John Honderich called me never once. There was one instance that he asked me if I would consider putting aside one column for a week because he thought that I needed to talk to one more person. And I did. I don't count that as interference. ${ }^{66}$

Sellar also states that he is proud that he "survived" at that job for eleven years and was not "burned out."

In reflecting about his long tenure, Sellar affirms that he may regret not writing about some issues that there were going on at the paper. He cites as an example special sections, such as travel supplements, that he felt didn't always follow the standards of the rest of the newspaper, such as who was paying for newsgathering expenses. "You know, these are heavily revenue sections and journalists are sloths sometimes. I should have done more, but I don't know if it would have made any difference," he declares.

Kathy English, who has held the position since May 2007, is very aware that the job entails a difficult balance:

\footnotetext{
${ }^{64}$ John Honderich, email interview, 10 Mar 2010.

${ }^{65}$ Sellar also served under David Jolley, and Michael Goldbloom.

${ }^{66}$ Don Sellar, telephone interview, 22 Jun 2009.
} 
Your role is to bite the hand that feeds you, to hold the newspaper to account. And you do, but you still work for an organization. You have to hold the paper to account and at the same time to be able to come back to work the next day, and work with people. I don't see my job as being an apologist for the paper. I do think that I explain the paper for the readers because I think generally readers do not understand a lot of the conventions and the culture of the journalism. ${ }^{67}$

English adds she hopes to be in the job long enough to "maybe" turn some of her columns and experiences as ombudsman into a book.

\section{Position guaranteed, at least for the moment}

The ombudsman's position seems to be secured at the Toronto Star, at least for awhile. Despite all the financial difficulties that the paper, like others, has been facing, publisher John Cruikshank states the Star has already done much to cut costs, and the public editor's position was not included:

You make those kinds of hard decisions in a balance. What is most important is how much you value the position. If it is a decision between the head of the editorial board and the ombudsman, well then maybe [it can be terminated], but that's a long way along the line from where we are today. ${ }^{68}$

Nevertheless, Cruickshank, along with editor in-chief Michael Cooke, points out newspapers have other options to reach and listen to their readers. ${ }^{69}$ Cooke, for instance, declares that while an ombudsman helps newsroom honesty and credibility, he doesn't necessarily recommend that others adopt this position:

It's expensive. And not everybody could afford it. There are lots of big newspapers in [North] America that do not have ombudsmen

\footnotetext{
${ }^{67}$ Kathy English, in person interview, 15 and 16 Jun 2009.

${ }^{68}$ John Cruikshank, telephone interview, 09 Jul 2009.

${ }^{69}$ Cruickshank has been Star publisher since November 2008, and Cooke, editor-in-chief since March 2009. They also worked together as publisher and editor-in-chief, respectively, of the Chicago Sun-Times.
} 
anymore, and they listen to readers. There are other ways to quiz a newsroom. There are other ways to listen to readers. ${ }^{70}$

Former ombudsman Don Sellar affirms that leadership helps protect the position: "I am confident that as long as John Honderich is at the Star, the paper will have a public editor." ${ }^{\text {71 }}$ Honderich, who now chairs Torstar's Board of Directors, seems indeed to be a believer in the position. He says the post not only adds credibility to a news organization, but also saves it money by avoiding libel suits. He does admit that its future is going to be "tough," considering economic pressures and newsroom downsizing. But asked what he would think if Cruickshank hypothetically cut the position, Honderich didn't seem to like the possibility: "I think I would want to talk about it first." It is important to secure the position as much as possible, he added. ${ }^{72}$

\section{A new time that came along}

Overall, executive editors say ombudsmen were important and served to make journalists more aware of the need for accountability. But they add that the ombudsman's era has gone by, as journalists become highly trained and more conscious of their responsibilities. Besides, they say, the Internet has brought easier two-way communication between readers and journalists, and the post, of course, is an expensive one.

Gazette publisher Alan Allnut, for instance, reflects on the new era and what role ombudsmen played:

\footnotetext{
${ }^{70}$ Michael Cooke, in person interview, 16 Jun 2009.

${ }^{71}$ Don Sellar, telephone interview, 22 Jun 2009.

72 John Honderich, telephone interview, 17 Jun 2009.
} 
I think daily newspapers in the 1960s, 1970s and early 1980s were in their sort of golden era. They were very powerful and income was not difficult to come by. I think that it was a very good time to have people watching almost external or independent what you were doing. We have had to become a lot more sensitive to what our readers are thinking, and doing, but also the subjects of coverage. I recall in the 70s, when I was first in the daily newspaper business, we never thought or debated or discussed whether we would run a picture of a victim's widow or a victim of some kind of crime. It was just done automatically. Today we have internal debates all the time about what is fair, what we should do or what we shouldn't do. The role that the ombudsmen played in the early 1980s has been to some extent adopted by other senior editors. The generation of editors that is now taking over the newsrooms have grown up in a complete different atmosphere. Particularly now with the Web, there is just an expectation that people can respond and can have their say. It is less of an issue at this point. The newspapers were always positioned as preaching, as pushing out to the audience without particularly responding to the audience. In the last ten or fifteen years that entire construct has changed. We understand that it is a two-way, a conversation. I think that mentality is in most newsrooms today. The ombudsman's position could have been either a step along the road and helped the development of somewhat more enlightened newsroom or maybe was a symbol of the fact that editors were becoming more enlightened, but they quite didn't know how to deal with it themselves so they appointed people to deal with it. ${ }^{73}$

Even those who didn't agree philosophically with ombudsmanship agree that the position once served a useful purpose. Murray Burt, managing editor of the Winnipeg

Free Press in the late 1980s, is a good example of that:

I was not in favour of ombudsmen. But I think in some circumstances, in some newspapers they have done a useful job sensitizing the newspaper staff to a need for more care, more accuracy, less arrogance. They also opened the eyes of the public that the editorial department was approachable if there were genuine disagreements. Newspaper people are more enlightened now, with formal academic instruction. Most of the people I

${ }^{73}$ Alan Allnut, telephone interview, 17 Sep 2009. 
worked with had come in at ground level and had worked their way up. ${ }^{74}$

If this new era is characterized by enlightened journalists, it is also true it is full of financial pressures. Rare it was to find, among my interviewees, a former editor or publisher who would implement the position again. "In a perfect world, I would," admits Philip McLeod, former editor of the London Free Press - a sentiment repeated by many others. They say the newspaper industry now pushes for more restricted use of budgets. Kevin Peterson, who as editor and publisher kept an ombudsman at the Calgary Herald for many years, is a good example of the change of mentality:

We were certainly making money and we had the resources to be able to invest in that. The position is an expensive investment and I will admit, if I had been a publisher ten years ago, when you had to make some tough economic decisions, I think a reporter is more valuable than an ombudsman. When you have to decrease the number of reporters I think at that point it is entirely appropriate to question whether this is a worthwhile investment of your resources. If I was a publisher now, I wouldn't even remotely put this in my agenda. The economics of the business is so tight that you are shrinking your newsroom gathering resources; and when economics are better, yes, you can afford something like this. But frankly it doesn't add the value that a good reporter does. And given that it is a senior position - a high salary - you can probably hire two junior reporters for the cost of paying for an ombudsman. I certainly opt for more reporters. ${ }^{75}$

\footnotetext{
${ }^{74}$ Murray Burt, telephone interview, 26 Sep 2009.

${ }^{75}$ Kevin Peterson, telephone interview, 26 Oct 2009.
} 


\section{Chapter 6 \\ CONCLUSION}

Newspaper ombudsmanship is a tool of media accountability. That accountability process occurs between two actors, the paper (through its ombudsman) and its audience. In implementing it, the newspaper voluntarily commits itself to provide a specific channel of communication that gives readers explanations (excuses or justifications) of the newspaper's conduct on the whole or in a particular story.

The audience, on the other hand, expects some standard of performance from the paper, even though these standards can vary greatly among the members of that audience and will therefore never reach a full consensus between the two actors, as was pointed out by scholars (pages 10 to 14). The audience trusts (to varying degrees) the newspaper's capability to perform a responsible job, and there is also no full agreement on what those responsibilities are. However, in general, there is an embedded responsibility in the news media's job because citizens, for instance, turn to them as their main source of information of what is going on (culturally and politically) in their city, state or province, country and abroad.

At the same time, news outlets are private firms and, to some extent, employ ombudsmen (and/or other means of accountability) out of self-interest. Some scholars have said that companies should be ethical and account for their behaviour because reputation counts in the success of a business. In the case of newspapers, there is practically no scholarly evidence of a direct relation between ombudsmanship and 
business success; ${ }^{1}$ but the openness created by the position shows a willingness to accept and handle customers' complaints, which in turn might lead to compensation, whether it be financial or in the form of public admiration (as Pritchard, Nemeth, McQuail, and Bertrand have all put it). ${ }^{2}$

In newspaper ombudsmanship, the accountability process happens internally, too. Ombudsmen request explanation from reporters and/or editors, and the latter become accountable to the former for their practices by responding to the inquiries. After weighing the facts, the ombudsman can write a memo to be distributed to the newsroom and/or publish his statement in his/her column.

In fact, the enforcement part of an ombudsman's accountability practice resides mostly in the public scrutiny that his or her judgement will have. This is what scholars have called the in-house critic component of ombudsmanship, and what journalists in general have referred to as the discomfort produced by "peer surveillance." The peer surveillance factor is indeed perceived through the loneliness that the position brings to ombudsmen, and the many wary reactions journalists have towards the ombudsman's job and pronouncements, especially when they are involved in the matter being discussed.

Ombudsmanship can provide a fairly fast resolution of readers' concerns. But in managing conflicts between readers and the newspaper, and/or improving an

\footnotetext{
${ }^{1}$ To my knowledge, there is only one study that makes reference to ombudsmanship and the maintenance of newspaper circulation figures over the years, as cited in chapter 2, footnote 58. (Philip Meyer, "Capacity Measures," In The Vanishing Newspaper: Saving Journalism in the Information Age, Columbia: University of Missouri Press, 2004, pages 171 and 172.)

${ }^{2}$ David Pritchard, "The Future of Media Accountability," in Holding the Media Accountable: Citizens, Ethics, and the Law, Bloomington: Indiana University Press, 2000; Neil Nemeth, News Ombudsmen in North America: Assessing an Experiment in Social Responsibility, Praeger: Westport, Conn, 2003; Denis McQuail, Media Accountability and Freedom of Publication, Oxford: Oxford University Press, 2003; and Claude Jean Bertrand, "The Arsenal of the $\mathrm{M}^{*} \mathrm{~A} * \mathrm{~S}$," in An Arsenal for Democracy: Media Accountability Systems, Hampton Press: Cresskill, New Jersey, 2003; and Media Ethics \& Accountability Systems, New Brunswick, N.J: Transaction Publishers, 2002.
} 
understanding between both, ombudsmen tend to be labelled as public relations practitioners. If public relations is by and large the "management of communication between an organization and its public," as Grunig and Hunt argue, ${ }^{3}$ then, in fact, this function derives inevitably from the ombudsman's position. But that does not necessarily diminish the ombudsman's ability to make the media accountable, a conclusion previously reached by Nemeth and Pritchard. ${ }^{4}$ After all, in establishing (or trying to establish) a good relationship with readers, ombudsmen provided explanations (and/or excuses and justifications) of the paper's behaviour, which is the essence of being accountable.

It appears that the position will always be expensive, because it demands journalists who are sufficiently experienced to explain the realities of newsgathering and also give a "respected" identity to the person who questions the reporters and editors. Arguably, however, others can handle readers' phone calls or emails, forward a reader's complaint to a reporter or editor, and research specific subjects, as have secretaries at the Star, Gazette and Calgary Herald.

Canadian papers employed ombudsmen largely for their own benefit, although they announced the implementation as something mainly beneficial for readers. All papers stressed that they were more approachable than ever - that readers would have an official channel of communication to whom they could vent their complaints or concerns. Ombudsmen would write columns explaining newsgathering processes and/or defending readers' complaints when that was justified, the promise continued.

\footnotetext{
${ }^{3}$ James E. Grunig and Todd Hunt, Managing Public Relations, New York: Holt, Rinehart \& Winston, 1984.

${ }^{4}$ Neil Nemeth, News Ombudsmen in North America: Assessing an Experiment in Social Responsibility, Praeger: Westport, Conn, 2003; and David Pritchard, "The Impact of Newspaper Ombudsmen on Journalists' Attitudes," Journalism Quarterly, Vol. 70, No. 1, 1993, Pp. 77-86.
} 
In general, ombudsmen fulfilled those roles. The success of each incumbent (if such measurement can ever be satisfactorily made) probably varied in degree. The reasons for that variation could be many, including: management's understanding of what the job should entail, how far the ombudsman was willing to exercise his or her duties as a critic, and the regard with which the ombudsman was seen by co-workers and bosses alike.

The columns informed readers about some cultures and practices of journalism, and explained newsrooms' conduct or in a specific story at large. The columns also provided criticism of the paper's performance, stating, for instance, that something could have been handled better or that an inexcusable mistake had occurred. On the basis of the columns reviewed for this thesis, it appears that criticism was limited to small scale. Ombudsmen, as experienced journalists and usually long-time employees, tended to give their opinions from the perspective of accepted professional practices; the propensity was in favour of the paper and/or journalism in general. At the same time, this is not to say that ombudsmen didn't agree with readers. In fact they sided with them in many occasions, and their judgements would depend on the circumstances of each case analysed, as discussed at pages 88 to 93 .

On the whole, my interviews indicate that the position was useful (and still is in the case of the Toronto Star). It made journalists more aware of their mistakes and sensitive to readers' concerns without pandering; they paid more attention to accuracy and fairness.

Former ombudsmen are in general among the most confident that the position was and still can be beneficial to readers, papers and journalists. As discussed in chapter 4, 
ombudsmen from other news organizations, however, linked their own success mostly to their conditions of employment, which they considered essential to the full exercise of their duties.

Indeed, evidence suggests that the terms under which the ombudsmanship process takes place are likely to affect the incumbent's performance. Canadian newspaper ombudsmen, for instance, had no contract ${ }^{5}$ and no fixed term limit. Although the majority of former Canadian ombudsmen interviewed said a contract would have made no difference, it seems fair to state that at least the press criticism part of ombudsmanship would have likely been more respected and safeguarded by at least the newsroom. Reporters overall tended to doubt the incumbents' independence to criticize management.

A specific term of tenure would have likely strengthened the position as well. Canadian ombudsmen usually stayed as many years as they wanted in their post. But if one knows that he/she is going to stay in that function for a short defined period and then move out, he/she may be more motivated for the entire term. That is certainly what Vince Carlin, Julie Miville-Dechêne, Andy Alexander and Jeffrey Dvorkin's statements imply. In any case, as we saw with Roger Edge and John Brown's long appointments at the Chronicle Herald and Edmonton Journal respectively, their busy lives in the beginning and middle of their terms diminished toward the end. Diminished, too, was the regard in which their role was held by management.

One solution, it seems, rests in turning to a discussion of what the ideal model of ombudsmanship is, knowing, nevertheless, that ombudsmanship will never become completely efficient - all systems have their fragilities - and could therefore not be sufficient by itself.

\footnotetext{
${ }^{5}$ As noted in Chapter 4, the exception was William MacPherson, Ottawa Citizen ombudsman.
} 
As pointed out, other news ombudsmen take their conditions of employment as essential for both incumbents (it assures, for instance, that they can be critical without fearing of being fired) and for readers (it gives transparency on the rules of the job, inciting trust in it).

In comparing their conditions with the ones encountered in Canadian newspaper ombudsmanship, I came to believe that the lack of a concrete, contractually fixed job description was the weakest point. To maximize this accountability system, it was necessary to have a proper arrangement, including a time limit, formal independence and a no-cut contract. As everything else in a business company, any new mechanism of "quality control" has to be structured, organized and periodically evaluated. Besides, the models of ombudsmanship at CBC and the Washington Post gives a good example of a stable and organized role. Actually, in the latter case, there is evidence that the job is still working strong and secure after 40 years. $^{6}$

Canadian papers abolished the post, alleging for the most part problems related to budgets and to a change in their appreciation of the job over the years. However, the latter reason appears really to be the number one factor.

The Ottawa Citizen, Montreal Gazette, London Free Press, and Calgary Herald claimed that cost was their main factor for letting ombudsmanship lapse, but former executive editors acknowledged as well that somehow the position was not perceived as an essential one. The Edmonton Journal and Calgary Herald stated clearly that the ombudsman acted as a buffer between journalists and readers, creating an unnecessary

\footnotetext{
${ }^{6}$ Kathy English makes reference to a speech by Post publisher Katharine Weymouth at the 2009 annual conference of the Organization of News Ombudsmen (ONO). Weymouth, according to English, affirmed her commitment to continue with the position at the paper. ("Why news ombuds matter," Toronto Star, May 23, 2009, p. 6)
} 
layer of communication and consequently difficulties within the newsroom. In the Sun's case, there were both financial and non-financial motives for the termination, but, judging by Alison's Downie comments, it seems fair to say that the Sun Media chain wouldn't likely continue anyway with ombudsmanship (or at least not continue with the criticism part of it). At the Winnipeg Free Press, Barry Mullin resigned following a controversy over a particular column with publisher Maurice Switzer. But the role was likely to change in the near future, if not cut, anyway: Switzer's understanding of the job didn't embrace criticism. At the Halifax Chronicle Herald and Sudbury Star, management felt the ombudsman's tasks could be handled by the newsroom alone; in others words, the position per se was not valued much anymore. The Winnipeg Tribune is the only case where it is difficult to assess the position, given the unavailability of former employees and the fact that termination resulted from the failure of the entire paper.

Even the most common arguments cited against ombudsmanship among my interviewees - the position is expensive; journalists and editors should listen to readers' complaints themselves, especially because they are more enlightened and/or professionalized in the field today; the new technological era makes it easier for readers to contact journalists and post their comments - are subject to inquiry. Flipside arguments would include: ombudsmen can make money by helping the paper avoid libel suits; an ombudsman doesn't mean that a complainant cannot be asked to speak with relevant reporters and editors first; professionalization do not imply that journalists will become capable of policing themselves better or being open-minded; and the internet does not guarantee that explanations and/or corrections will be made easily or promptly if there is no one specific person to deal with them. 
But none of those arguments seems to matter now. The evidence suggests that newspaper ombudsmanship in Canada is not likely to come back, at least for the foreseeable future. Even former advocates said that they would not employ it anymore.

The ombudsman's post at the Toronto Star marked its $38^{\text {th }}$ anniversary in May 2010. It is the only one left in the country. It is likely to continue its path for awhile, until budgetary struggles become worse, or John Honderich's advocacy for the post fades away. Besides, some Star ombudsmen have faced problems in the past and others can face them in the future.

Different analysis on newspaper ombudsmanship in Canada and, of course, elsewhere can be examined. To my knowledge there is no published scholarly research on why newspaper ombudsmanship has disappeared.

Whether ombudsmanship strengthens the bond between readers and newsroom remains unknown. The relation between ombudsmanship and business success is also unexplored. Future research could usefully develop a study among Toronto Star readers to explore these areas and it could also attempt to measure their appreciation of the position.

In addition, a comparative study could usefully explore ombudsmanship in other countries, such as in the United States, Brazil, and England, where the position was adopted by a few newspapers and has also been gradually eliminated. Such research would shed light on the factors affecting the implementation, development and abolition of the position, helping determine how each national context played a role. How would those differ from Canada? As Wahab points out (footnote 4 on page 30), even 
government ombudsmanship has being adapted by the countries to best suit their characteristics - and this might be the case with newspaper ombudsmanship as well. ${ }^{7}$

A study could also compare newspapers that have been employing ombudsmen for a long time. The future research could usefully try to indicate if there are similarities across the papers that could explain the long success of their ombudsmanship as a tool of media accountability.

All in all, gaps remain in our knowledge about this subject; gaps that can also tell us much about the history and characteristics of the news media more generally. As Pritchard says, media accountability systems reflect the character of the communities and countries in which they are found. ${ }^{8}$ I agree with the scholar and believe that newspaper ombudsmanship specifically can say much about this society and this country. This is not something that I aimed to study or answer here, of course, but it was something that persuaded me to do this research - research that I am glad and proud to have done.

\footnotetext{
${ }^{7}$ Ibrahim Ismail Wahab, The Swedish Institution of Ombudsman: an Instrument of Human Rights, Stockholm: LiberFörlag, 1979.

${ }^{8}$ David Pritchard, "The Process of Media Accountability," in Holding the Media Accountable: Citizens, Ethics, and the Law. Bloomington: Indiana University Press, 2000, pages 3 and 4.
} 


\section{LIST OF SOURCES}

\section{Interviews}

\section{$\underline{\text { Toronto Star }}$}

Balkissoon, Denise. Reporter. Email interview, 16 Aug 2010.

Burnside, Sharon. Former ombudsman. Telephone interview, 25 Jun 2009.

Cooke, Michael. Editor-in-chief. In-person interview, 16 Jun 2009.

Cruickshank, John. Publisher. Telephone interview, 09 Jul 2009.

English, Kathy. Public editor. In-person interview, 15 and 16 Jun 2009.

Gherson, Giles. Former editor-in-chief. Telephone interview, 05 Nov 2009.

Goar, Carol. Columnist and Editorial Board. Email interview, 26 Mar 2010.

Goodman, Rod. Former ombudsman. Telephone interview, 14 Jul 2009.

Harvey, Robin. Former ombudsman. In-person interview, 15 Oct 2009; email interview, 15 Apr 2010.

Hepburn, Bob. Communications editor. In-person interview, 16 Jun 2009.

Honderich, John. Former publisher. Telephone interview, 17 Jun 2009; email interview, 10 Mar 2010.

Kuntz, Fred. Former editor-in-chief. Telephone interview, 22 Oct 2009.

McDonnell, Liz. Public editor associate. In-person interview, 15 Jun 2009.

Stancu, Henry. Reporter. Email interview, 20 Aug 2010.

Sellar, Don. Former ombudsman. Telephone interview, 22 Jun 2009; email interviews, 9 Mar and 13 Apr 2010.

Shears, Mary Deanne. Former managing editor. Telephone interview, 08 Feb 2010.

Urquhart, Ian. Editorial page editor. In-person interview, 16 Jun 2009.

Vander Doelen, Joan. Former ombudsman associate. In-person interview, 15 Jun 2009. 


\section{$\underline{\text { Montreal Gazette }}$}

Allnutt, Alan. Publisher. Telephone interview, 17 Sep 2009.

Balfour, Clair. Former ombudsman. Telephone interview, 01 Sep 2009.

Brassard, Raymond. Managing editor. Telephone interview, 21 Jul 2009.

Davey, Clark. Former publisher. Telephone interview, 06 Jul 2009; email interview, 10 Jul 2009. ${ }^{1}$

Goldbloom, Michael. Former publisher. Telephone interview, 22 Jul 2009. ${ }^{2}$

Whittaker, Stephanie. Former ombudsman. Telephone interview, 16 Jul 2009.

\section{Winnipeg Free Press}

Burt, Murray. Former managing editor. Telephone interview, 26 Sep 2009.

Hirst, Nicholas. Former editor. Telephone interview, 23 Sep 2009.

Lee, Dave. Former managing editor. Telephone interview, 29 Oct 2009.

Mullin, Barry. Former ombudsman. Telephone interview, 17 Oct 2009; email interview, $27 \mathrm{Jul} 2010$.

Pona, Steve. Business editor. Telephone interview, 30 Sep 2009.

Switzer, Maurice. Former publisher. Telephone interview, 19 Oct 2009; email interview, 10 Mar 2009. ${ }^{3}$

\section{Ottawa Citizen}

Butler, Don. Former executive editor. Telephone interview, 13 Aug 2009.

Calamai, Peter. Former managing editor. Telephone interview, 22 Oct 2009.

Gordon, Charles. Reporter and former editor. Telephone interview, 24 Sep 2009.

Mills, Russ. Former publisher. In-person interview, 11 Aug 2009.

Spencer, Christina. Former editor. Telephone interview, 30 Sep 2009.

\footnotetext{
${ }^{1}$ Davey was also interviewed as former publisher of the Ottawa Citizen.

${ }^{2}$ Goldbloom was also interviewed as former publisher of the Toronto Star.

${ }^{3}$ Switzer was also interviewed as former publisher of the Sudbury Star.
} 


\section{$\underline{\text { Toronto Sun }}$}

Downie, Alison. Former readership editor. Telephone interview, 24 Jul 2009; email interview, 19 Apr 2010.

Fowler, Neil. Former publisher. Telephone interview, 21 Oct 2009.

Garnett, Glenn. Former Editor-in-chief. Telephone interview, 14 Aug 2009.

Jennings, Jim. Former editor-in-chief. Telephone interview, 17 Jul 2009.

Strobel, Mike. Reporter. Telephone interview, 28 Sep 2009.

\section{London Free Press}

Berton, Paul. Editor-in-chief. Telephone interview, 28 Sep 2009.

Martin, Chip. Reporter. Telephone interview, 28 Sep 2009.

McLeod, Phillip. Former editor-in-chief. Telephone interview, 15 Sep 2009.

Miner, John. Reporter and former editor. Telephone interview, 28 Sep 2009.

Sanderson, Gordon. Former ombudsman. Telephone interview, 30 Sep 2009.

\section{Chronicle Herald}

De Palma, Frank. Managing editor. Telephone interview, 30 Sep 2009.

Edge, Roger. Former ombudsman. Telephone interview, 09 Nov 2009; email interview, 01 Mar 2010.

Howse, Bob. Editor-in-chief. Email interviews, 07 and 10 Nov 2009.

O’Neil, Terry. Former managing editor. Telephone interview, 30 Nov 2009.

Purves, Jane. Former managing editor. Telephone interview, 01 Oct 2009.

\section{Edmonton Journal}

Cashman, Paul. Reporter. Telephone interview, 05 Nov 2009.

Davis, Murdoch. Former editor-in-chief. Email interview, 16 Oct 2009.

Hughes, Linda. Former publisher. Telephone interview, 05 Oct 2009. 
Mayer, Allan. Editor-in-chief. Telephone interview, 26 Oct 2009.

Newbigging, Bill. Former publisher. Telephone interview, 09 Nov 2009.

\section{Calgary Herald}

Cotton, Crosbie. Former editor. Telephone interview, 28 Sep 2009.

Cunningham, Jim. Former reporter. Email interview, 01 Dec 2009.

Ford, Catherine. Former columnist. Telephone interview, 12 Nov 2009; email interview, 13 Jul 2010.

Peterson, Kevin. Former publisher and editor. Telephone interview, 26 Oct 2009.

Steward, Gillian. Former managing editor. Telephone interview, 09 Nov 2009.

\section{$\underline{\text { Sudbury Star }}$}

Cazabon, Roger. Former managing editor. Email interview, 06 Nov 2009.

Hrybinski, Boris. Former managing editor. Telephone interview, 09 Nov 2009.

Krejlgaard, Chris. Former ombudsman. Telephone interview, 28 Oct 2009.

MacDonald, Don. City editor. Telephone interview, 09 Nov 2009.

\section{Other institutions}

Alexander, Andy. Ombudsman, Washington Post. Telephone interview, 27 Oct 2009.

Carlin, Vince. Ombudsman, CBC. Telephone interview, 26 Oct 2009.

Dvorkin, Jeffrey. Executive director, Organization of News Ombudsmen (ONO).

Telephone interview, 22 Oct 2009.

Elgie, Robert G. Chair, Ontario Press Council. Telephone interview, 30 Nov 2009.

Lubrano, Gina. Former executive secretary, Organization of News Ombudsmen (ONO).

Email interview, 10 Oct 2008; telephone interview, 4 Mar 2009.

Marshall, Laura. CBC ombudsman's assistant. Email interview, 12 Mar 2010.

Miville-Dechêne, Julie. Ombudsman, Radio Canada. Telephone interview, 29 Oct 2009. 
Owen, Gerald. Reader response editor, Globe and Mail. Telephone interviews, 10 and 24 Sep 2009.

Rose, Rollie. Executive director, British Columbia Press Council. Email interview, 25 Mar 2010.

Stubbs, Lewis St. George. Research and reference person for the University of Manitoba Archives and Special Collections. Email interviews, 25 Feb 03 and 17 Mar 2010.

Sufrin, Mel. Executive secretary, Ontario Press Council. Email interview, 14 Apr 2010. Tuominen, Liisa. Ottawa Citizen librarian. Email interview, 9 Mar 2010.

Wilson, Colleen. Executive secretary-treasurer, Alberta Press Council. Email interview, 25 Mar 2010.

\section{Ombudsman columns cited}

Balfour, Clair. "To name or not to name, that's the question," Montreal Gazette, Apr. 11, 1985, p. B3.

Balfour, Clair. "Headline gave story unjustified weight," Montreal Gazette, Nov. 21, 1985, p. B3.

Balfour, Clair. "What The Gazette looks for in letters to the editor," Montreal Gazette, Aug. 15, 1988, p. B3.

Briglia, Jack. "Openness and credibility ombudsman's basic concern," London Free Press, Jan. 30, 1985, p. A13.

Briglia, Jack. "If readers aren't given the facts they get the wrong idea," London Free Press, Feb. 6, 1985, p. A15.

Briglia, Jack. "The case against naming names," London Free Press, Jul. 3, 1985, p. A11.

Briglia, Jack. "Perceptions of stories vary from reader to reader," London Free Press, Dec. 11, 1985, p. A15.

Briglia, Jack. "Pictures again year's biggest problem," London Free Press, Feb. 2, 1991, p. E2.

Brown, John. "If we erred, call me," Edmonton Journal, Jun. 30, 1978, p.1.

Brown, John. "A busy week with our readers," Edmonton Journal, Jul. 7, 1978, p. A5. 
Brown, John. "Solution through compromise," Edmonton Journal, Jan. 4, 1980, p. A6.

Brown, John. "Ombudsmen's world proves small, indeed," Edmonton Journal, May 22, 1990 , p. A17.

Brown, John. "Public doesn't know how to read newspaper," Edmonton Journal, Jan. 13, 1992, p. A10.

Brown, John. "Letters a reflection of public opinion," Edmonton Journal, May 10, 1993, p. A8.

Brown, John. "Children's photo upset many readers," Edmonton Journal, Apr. 27, 1992, p. A8.

Burnside, Sharon. "Let me get this right, I'm here to serve," Toronto Star, Mar. 12, 2005, p. F06.

Burnside, Sharon. "You be the editor," Toronto Star, Dec. 26, 2005, p. A29.

Burnside, Sharon. "Plagiarism an issue of trust," Toronto Star, Oct. 15, 2005, p. H06

Burnside, Sharon. "Star coverage failed vital test," Toronto Star, Oct. 21, 2006, p. F6.

Cross, Dave. "Sparse rural coverage deplored," Winnipeg Tribune, Dec. 29, 1979, p. 9.

Downie, Alison. "Meet your new advocate; we've appointed Alison Downie as our first Sun Readership Editor. She's on your side," Toronto Sun, June 5, 2005, p. 2 A.

Downie, Alison. "Readers call - We listen; In her first week, readership editor Alison Downie learns all about crossword rage," Toronto Sun, Jun. 12, 2005, p. 2.

Downie, Alison. "Balancing news and family privacy," Toronto Sun, Nov. 13, 2005, p. C3.

Downie, Alison. "Public life can be such a b..." Toronto Sun, Nov. 5, 2006, p. C3.

Edge, Roger. "Keep those letters coming - but be patient," Chronicle Herald, Feb. 11, 2000, p. C2.

Edge, Roger. "Sunday columnists take heat from readers," Chronicle Herald, Mar. 24, 2000, p. B2.

Edge, Roger. "Got a news story? We're approachable," Chronicle Herald, Feb. 9, 2001, p. C2.

Edge, Roger. “Occasionally, change is for better," Chronicle Herald, Jun. 1, 2001, p.C2.

English, Kathy. "Journalism and Jiminy Cricket," Toronto Star, Apr. 19, 2008, p. A4 
English, Kathy. "Our commitment to credibility," Toronto Star, Jun. 16, 2007, p. A6.

English, Kathy. "Public interest and private grief," Toronto Star, Jul. 12, 2008, p. A6.

English, Kathy. "Why news ombuds matter," Toronto Star, May 23, 2009, p. A6.

English, Kathy. "The Star's 'unforgivable' error," Toronto Star, May 22, 2010, p. A6.

English, Kathy. "Who decides what's news?" Toronto Star, May 1, 2010, p.A6.

English, Kathy. "Readers, now you be the editor," Toronto Star, Jan. 3, 2009, p. A4.

Gardner, Ray. "The headline is The Story," Toronto Star, Mar. 13, 1982, p. B2.

Gardner, Ray. "Much too close for comfort," Toronto Star, Apr. 10, 1982, p. B2.

Gardner, Ray. "Publication ban is best course," Toronto Star, May 22, 1982, p. B6.

Gold, William. "Columnist's criticism of left fulfilled role," Calgary Herald, Jan. 3, 1985, p. A10.

Gold, William. "Listening, Ralph Ponskum? Don't call me again," Calgary Herald, Sep. 4, 1985, p. A11.

Goodman, Rod. "Did photo of grief at policeman's funeral invade privacy?", Toronto Star, Sep. 14, 1984, p. A14.

Goodman, Rod. "A year in the life of Star's ombudsman," Toronto Star, Dec. 31, 1988, p. D2.

Goodman, Rod. "24 editors of my ilk swap ideas," Toronto Star, Jun. 13, 1992, p. A16.

Goodman, Rod. "Vigilant readers: Thanks for caring," Toronto Star, Aug. 29, 1992, p. D2.

Goodwin, Dick. "An end and a beginning," Winnipeg Tribune, Jun. 2, 1979, p. 9B.

Goodwin, Dick. "Score for lawyer, zero for CP and us," Winnipeg Tribune, Sep. 13, 1975, p. 9.

Harrison, Mark. "Newspaper errors underline need for ways to ensure accuracy," Toronto Star, Jun. 3, 1972, p. 17.

Harrison, Mark. "'We try to be fair - but it's in the eye of the beholder'," Toronto Star, Dec. 16, 1972, p. 22.

Harrison, Mark. "Headlines: They can create - and compound - the error," Toronto Star, Feb. 24, 1973, p. 20. 
Harvey, Robin. "Some proud coverage in recent weeks," Toronto Star, Mar. 10, 2001, p. J6.

Harvey, Robin. "Errors and apologies," Toronto Star, Aug. 11, 2001, p. H6.

Harvey, Robin. "Slaughterhouse operator deserved his say," Toronto Star, Dec. 23, 2000, p. 6.

Harvey, Robin. "Correcting the corrections," Toronto Star, Apr. 7, 2001, p. K6.

Krejlgaard, Chris. "Is Star's Sunthetic coverage biased?" Sudbury Star, Dec. 11, 1992, p. 6.

Krejlgaard, Chris. "Would the Star follow politicians' affair?" Sudbury Star, Mar. 19, 1993, p. A6.

Krejlgaard, Chris. "Just who's responsible for bad press?" Sudbury Star, May 6, 1994, p. 6.

MacPherson, William. “Ombudsman's role a buffer against injustice," Ottawa Citizen, Mar. 10, 1990, p. P. B3.

MacPherson, William. "Columnists are expected to state strong opinions," Ottawa Citizen, Jun. 9, 1990, p. B7.

MacPherson, William. "Newspaper ombudsmen: they lead a lonely, arm's-length existence," Ottawa Citizen, Jun. 20, 1992, p. A13.

Mullin, Barry. "Front-page error creates chance to needle ombudsman," Winnipeg Free Press, Nov. 6, 1987, p.2.

Mullin, Barry. "Subscribers missed front-page L.A. riot story," Winnipeg Free Press, May 1, 1992, p. 7.

O'Hara, Larry. "A new way for the readers to talk to The Herald," Calgary Herald, Dec. 7, 1982, p. A8.

O'Hara, Larry. "Professional reviewers needn't agree with the audience," Calgary Herald, Jan. 4, 1983, p. A7.

O'Hara, Larry. "It's been interesting - even the call from 'God'," Calgary Herald, Oct. 29,1984 , p. A10.

Sanderson, Gordon. "Reader's advocate hopes to achieve fair balance," London Free Press, Feb. 16, 1991, p. A2.

Sanderson, Gordon. "Reader's advocate bids farewell," London Free Press, Sep. 30, 1995, p. A2. 
Sellar, Don. "You Be the Editor It's your call," Toronto Star, Dec. 18, 2004, p. H6.

Sellar, Don. "You Be The Editor Your call," Toronto Star, Jul 24, 2004, p. H6.

Sellar, Don. "You be the editor It's your call," Toronto Star, Mar 13, 2004, p. F6.

Sellar, Don. "You be the editor It's your call," Toronto Star, Dec. 13, 2003, p. E6.

Sellar, Don. "You be editor for a day," Toronto Star, Aug. 30, 1997, p. B2.

Sellar, Don. “As editor, you make the calls," Toronto Star, Apr 5, 1997, p. B2.

Sellar, Don. "Let's put columnists on a diet," Toronto Star, Nov. 13, 2004, p. H6.

Sellar, Don. "Another one bites the dust," Toronto Star, Feb. 24, 1996, p. B2.

Sellar, Don. "U.S. article was plagiarized," Toronto Star, Apr. 15, 2004, p. A24.

Spears, Borden. "Press must be critical of its criticism too," Toronto Star, Aug. 30, 1975, p. B2.

Spears, Borden. "The press modestly disclaims the role of a savior," Toronto Star, Apr. 12, 1975, p. B2.

Spears, Borden. "Toward a code of media ethics," Toronto Star, Dec. 24, 1979, p. A8.

Spears, Borden. "Misleading headline really misled," Toronto Star, Jan. 27, 1979, p. C2.

Stott, Jim. "It's time for this ombudsman to fly alone at the controls," Calgary Herald, Sep. 05, 1985 p. A11.

Stott, Jim. "Just in case you wondered, a journalist is..." Calgary Herald, Jun. 20, 1993, p. A7.

Stott, Jim. "More journalists should 'bleed over their mistakes'," Calgary Herald, Dec. 24, 1995, p. A7.

Stott, Jim. "Herald was wrong to publish photograph," Calgary Herald, May 7, 1995, p. A7

Stott, Jim. "Readers, editors seldom agree on news," Calgary Herald, Feb. 28, 1993, p. A7.

Stott, Jim. "Let 400,000 readers know what's on your mind," Calgary Herald, Oct 29, 1995. p. A.7

Stott, Jim. "After 30,000 calls and 400 columns -- that's a wrap: Veteran journalist bids adieu after 10 years as ombudsman," Calgary Herald, Jan. 28, 1996, p. A7. 
Timson, Ray. "When public interest collides with personal privacy," Toronto Star, Nov. 28, 1981, p. B2.

Timson, Ray. "Should we name the accused?" Toronto Star, Dec. 19, 1981, p. B2.

Timson, Ray. "Lady Luck didn't smile for us," Toronto Star, Jan. 2, 1982, p. B2.

Walker, Robert. "McGill ethics students hated picture of dying umpire," Montreal Gazette, Apr. 15, 1996, p. B3.

Walker, Robert. "How would you make these four editorial decisions?" Montreal Gazette, March 25, 1996, p. B3.

Walker, Robert. "Improve the chances that your letter will be printed," Montreal Gazette, Feb. 19, 1996, p. B3.

Walker, Robert. "How to improve the chances that your letter will be printed," Montreal Gazette, Sep. 12, 1994, p. B3.

Walker, Robert. "How we decide which stories should be on the front page," Montreal Gazette, Aug. 28, 1995, p. B3.

Walker, Robert. "Errors of fact top the hate list; Ombudsmen say key job is guarding credibility," Montreal Gazette, Nov. 26, 1990, p. B3.

Walker, Robert. "Departing ombudsman thanks readers," Montreal Gazette, May 27, 1996 , p. B3.

Whittaker, Stephanie. "Media ethics threatened when 'scoop mania' reigns," Montreal Gazette, Jan. 30, 1989, p. B3.

Whittaker, Stephanie. "Inane' story was designed to provide amusement," Montreal Gazette, Mar. 27, 1989, p. B3.

Whittaker, Stephanie. "Here's what newspaper's ombudsman aims to do," Montreal Gazette, Apr. 3, 1989, p. B3.

Whittaker, Stephanie. "The Gazette erred in not running Doonesbury strips," Montreal Gazette, Apr. 10, 1989, p. B3.

Whittaker, Stephanie. "Decision on space agency story was not partisan," Montreal Gazette, Mar. 13, 1989, p. B3.

Whittaker, Stephanie. "Newspapers shrink from reporting on themselves," Montreal Gazette, Mar. 6, 1989, p. B3.

Worth, Roger. "The Ombudsman: a spokesman for Star readers," Sudbury Star, Sep. 7, 1990 , p. A5. 
Worth, Roger. "Perceptions not necessarily truths," Sudbury Star, Mar. 1, 1991, p. 4.

Worth, Roger. "Why are some stories given prominence?" Sudbury Star, Sep. 6, 1991, p. 6.

Worth, Roger. "The ombudsman: yes, we do want to hear from readers," Sudbury Star, Sep. 14, 1990, p. A5.

\section{Other newspaper columns and articles cited}

Balkissoon, Denise, and Stancu, Henry. "Gang connection investigated in killing of boy, 15," Toronto Star, May 18, 2010, p. 1.

Boras, Alan. "Herald publisher resigns," Calgary Herald, Dec. 13, 1995, p. 1.

Boras, Alan. "Interim Herald publisher named," Calgary Herald, Dec. 20, 1995, p. C1.

Boras, Alan. "New Herald publisher appointed," Calgary Herald, Jan. 30, 1996, p. 1.

Brown, Dave. “Ombudsman makes me work harder," Ottawa Citizen, May 27, 1991, p. C1.

Clark, Roy Peter. "Press deserves some respect," Toronto Star, Oct. 7, 2006, p. F6.

Cobb, Chris. "Media; Winnipeg Free Press fires ombudsman," Ottawa Citizen, May 6, 1992, p. A5.

Cobb, Chris. "Ombudsman fired for L.A. riot column," Vancouver Sun, May 6, 1992, p. A4.

Cotton, Crosbie. "Herald bids good-bye to ombudsman," Calgary Herald, Jan. 28, 1996, p. A2.

Connery, Allan. "Herald scribe kept calm," Calgary Herald, Jun. 9, 2005, p. B13.

Davis, Murdoch. "The Journal pledges to listen directly to the readers; How to call us," Edmonton Journal, Jun. 12, 1993, p. A2.

Evans, Patrick. "Jack Cahill 'He was one of the last old-time journalists'; Globe- trotting reporter, author dies at age 79 Best way to get a story was 'to see it, feel it, touch it',"' Toronto Star, Jul. 7, 2005 , p. A10.

Fisher, Gordon. "Got a gripe with us? Call your ombudsman," Ottawa Citizen, Mar. 3, 1990, p. B3. 
May, Kathryn. "Southam executive returns to the Citizen, Russell Mills to replace Clark Davey as publisher," Ottawa Citizen, Oct. 29, 1992, p. A2.

McLeod, Philip. "A new approach to readers' complaints," London Free Press, Feb. 9, 1991, p. E2.

McLeod, Philip. “Editor's note,” London Free Press, Sep. 30, 1995, p. A2.

Roberts, David. "Winnipeg: Departure of newsman puts paper in spotlight," Globe and Mail, May 7, 1992, p. A6.

Toughill, Kelly. “Official 'scoops' double dupe,” Toronto Star, Sep. 2, 2006, p. F6.

“Apology," Toronto Star, May 19, 2010, p. 2.

"Borden Spears named 'Man at the Star', Reynolds city editor," Toronto Star, Jan. 21, 1974 , p. A3.

"Editor to represent public in newsroom," Toronto Star, May 6, 1972, front page.

"FP selects columnist as first ombudsman," Winnipeg Free Press, Oct. 28, 1987, p. 1.

“Gazette names reader representative," Montreal Gazette, Jun. 5, 1981, p. 1.

"Handling of ombudsman by paper draws criticism," Toronto Star, May 14, 1992, p. A14.

“Journal appoints own ombudsman," Edmonton Journal, Jun. 10, 1978, p. A2.

“Ombudsman named," Calgary Herald, Dec. 7, 1982, p. 1.

“Ombudsman appointed," Chronicle Herald, Jan. 16, 1993, front page.

"Ombudsman Jack Briglia your advocate at the Free Press starting today!" London Free Press, Jan. 30, 1985, p. 1.

"Ombudsman's appointment gives readers a voice at the Citizen," Ottawa Citizen, Jan. 24, 1990, p.1.

"Ray Timson takes charge of Star's accuracy bureau," Toronto Star, Aug. 30, 1980, p. A2.

"Sun's news boss resigns post," Toronto Sun, Sep. 21, 2006, p. 6.

“Tribune readers get an ombudsman”, Winnipeg Tribune, Aug. 30, 1975, page unknown.

“Top critic Ken Adachi dies at 60," Toronto Star, Feb. 11, 1989, p. A3.

“The ombudsman - New voice for Star readers," Sudbury Star, Sep. 7, 1990, p. 1. 
"Veteran editor Ray Gardner appointed Star ombudsman," Toronto Star, Feb. 13, 1982, p. A3.

"Winnipeg Free Press; Association criticizes ombudsman restrictions," Ottawa Citizen, May 14, 1992, p. A7.

\section{Books, articles and documents}

Adam, G. Stuart. "The Journalistic Imagination." In Journalism Communication and the Law. Scarborough: Prentice-Hall, 1976.

Axworthy, Thomas S. "The Accountability Ladder: Five Steps Toward Democracy." Paper prepared for the World Forum on the Democratization of Asia, Taipei, Taiwan. September 15-17, 2005.

Bardoel, Jo, and D'Haenens, Leen. "Media Responsibility and Accountability: New Conceptualizations and Practices." Communications: The European Journal of Communication Research, Vol. 29, No.1, 2004. Pp.5-25.

Bernstein, James M. "The Public's View of Newspaper Accountability." Newspaper Research Journal. Vol. 7, No. 2, 1986. Pp. 1-9.

Bertrand, Claude Jean. Media Ethics \& Accountability Systems. New Brunswick, NJ: Transaction Publishers, 2002.

Bertrand, Claude Jean. "A Predicament and Three Solutions." In An Arsenal for Democracy: Media Accountability Systems. Cresskill, New Jersey: Hampton Press; 2003.

Bertrand, Claude Jean. "The Arsenal of the M*A*S." In An Arsenal for Democracy: Media Accountability Systems. Cresskill, New Jersey: Hampton Press; 2003.

Bertrand, Claude Jean. "Conclusion." In An Arsenal for Democracy: Media Accountability Systems. Cresskill, New Jersey: Hampton Press; 2003.

Bridges, Lamar W., and Bridges, Janet A. "Newspaper Ombudsman Role During Presidential Campaign." Newspaper Research Journal. Vol. 16, No. 2, 1995. Pp. 76-90.

Boeyink, David E. "How Effective Are Codes of Ethics? A Look at Three Newsrooms." Journalism Quarterly. Vol. 71, No. 4, 1994. Pp. 893-904.

Bunton, Kristie. "Media Criticism as Professional Self-Regulation." In Holding the Media Accountable: Citizens, Ethics, and the Law. Bloomington: Indiana University Press, 2000. 
Canadian Advertising Rates and Data. December 1978, Vol. 51, No. 12, p. 7 and 11; January 1982, Vol.55, No.1, 7 and 24; January 1988, Vol. 61, No.1, p. 12; February 1985, Vol. 58, No.2, p. 14; and January 1991, Vol. 64, No.1, p. 16, 19 and 27.

Christians, Clifford. "Self-Regulation: a Critical Role for Codes of Ethics." In Media Freedom and Accountability. New York: Greenwood Press, 1989.

Christians, Clifford. "Social Responsibility, Corporate Morality, and Codes of Ethics." In An Arsenal for Democracy: Media Accountability Systems. Cresskill, New Jersey: Hampton Press; 2003.

Cline, Andrew. "Ethics and Ethos: Writing an Effective Newspaper Ombudsman Position." Journal of Mass Media Ethics. Vol. 23, No. 2, 2008. Pp. 79-89.

Damas, Susana H. "Situacion Del Ombudsman en el Mundo." Revista de Comunicacion. Vol. 4, 2005. Pp. 17-37.

Desbarats, Peter. “Accountability.” In Guide to Canadian News Media. Toronto: Harcourt Brace Canada, 1996. 2nd Ed.

Dennis, Everette E. “Conclusion.” In Media Freedom and Accountability. New York: Greenwood Press, 1989.

Dornan, Christopher. "Free to be Responsible: the Accountability of the Print Media." In Reporting the Campaign: Electoral Coverage in Canada. Toronto: Dundurn Press Limited, 1991.

Dumenco, Simon. "Is the Newspaper Ombudsman More or Less Obsolete?" Advertising Age. Vol. 79, No.12, 2008. Pp.18.

Dvorkin, Jeffrey. "Death of the Ombud? Only in Canada." The Canadian Journalism Project. In www.jsource.ca/english_new/detail.php?id=4320 [accessed October 20, 2009].

Dvorkin, Jeffrey. "News Ombudsmen and Stress." Dart Center for Journalism \&Trauma. In dartcenter.org/content/news-ombudsmen-and-stress [accessed October 21, 2009].

Elliott, Deni. "Foundations for News Media Responsibility." In Responsible Journalism. Beverly Hills, Calif: Sage Publications, 1986.

Ettema, James, and Glasser, Theodore L. "Public Accountability or Public Relations? Newspaper Ombudsmen Define Their Role." Journalism Quarterly. Vol. 64, No.1, 1987. Pp. 3-12.

Fenstermacher, Gary D. "Educational Accountability: Features of the Concept." Theory Into Practice. Vol. 18, No.5, 2001. Pp. 330-335. 
Glasser, Theodore L. "The Newspaper Ombudsman and the Aim of Accountability in American Journalism." In An Arsenal for Democracy: Media Accountability Systems. Cresskill, New Jersey: Hampton Press; 2003.

Glasser, Theodore L. "Three Views on Accountability." In Media Freedom and Accountability. New York: Greenwood Press, 1989.

Grunig, James E., and Hunt, Todd. Managing Public Relations. New York: Holt, Rinehart \& Winston, 1984.

Harding, Katherine M. "Death of Newspaper Ombudsmen: Why Canadian Newspapers Have Abandoned their Watchdogs.” Master's Research Project, Carleton University, April 2001.

Hartung, Barbara; Jacoby, Alfred, and Dozier, David. "Readers' Perceptions of Purpose Of Newspaper Ombudsman Program.” Journalism Quarterly. Vol. 65, No.4, 1988. Pp. 914-919.

Henry III, William A. "Freedom and Accountability: A Search for Solutions," In Media Freedom and Accountability. New York: Greenwood Press, 1989.

Hickey, Neil. "Public Editor's Private Story." Columbia Journalism Review. Vol. 44, No.1, 2005. Pp. 24-27.

Hodges, Louis W. "Defining Press Responsibility: a Functional Approach." In Responsible Journalism. Beverly Hills, Calif.: Sage Publications, 1986.

Höpfl, Harro M. "The Critical Issue of Accountability." In Critical Theory Ethics for Business and Public Administration. Charlotte, NC: Information Age Pub., 2008.

JaCoby, Alfred. "The Newspaper Ombudsman: a Personal Memoir of the Early Days." In www.newsombudsmen.org/jacoby [accessed October 16, 2009].

Kaler, John. "Responsibility, Accountability and Governance.” Business Ethics: A European Review. Vol. 11, No.4, 2002. Pp. 327-334.

Langlois, Simon, and Sauvageau, Florian. "L'image de L'ombudsman de Presse dans Deux Quotidiens Canadiens.” Communication Information. Vol.10, No.2/3, 1989. Pp.189-210.

Lundvik, Ulf. The Ombudsmen in the Provinces of Canada. Edmonton, Alta.: International Ombudsman Institute, 1981.

Maezawa, Takeshi. "The Controversy Over the Origins and Functions of Ombudsmanship." In www.newsombudsmen.org/maezawa [accessed October 16, 2008].

McQuail, Denis. Media Accountability and Freedom of Publication. Oxford: Oxford University Press, 2003. 
Meyer, Philip. "Capacity Measures." In The Vanishing Newspaper: Saving Journalism in the Information Age. Columbia: University of Missouri Press, 2004.

Meyers, Christopher. "Creating an Effective Newspaper Ombudsman Position." Journal of Mass Media Ethics. Vol. 15, No.4, 2000. Pp. 248-256.

Merrill, John C. "Three Theories of Press Responsibility and the Advantages of Pluralistic Individualism." In Responsible Journalism. Beverly Hills, Calif.: Sage Publications, 1986.

Mogavero, Donald T. “The American Press Ombudsman." Journalism Quarterly. Vol. 59, No.4, 1982. Pp. 548-580.

Nelson, David R., and Starck, Kenneth. "The Newspaper Ombudsman as Viewed by the Rest of the Staff." Journalism Quarterly. Vol. 59, 1974. Pp. 453-457.

Nemeth, Neil. News Ombudsmen in North America: Assessing an Experiment in Social Responsibility. Praeger: Westport, Conn, 2003.

Nemeth, Neil. "A News Ombudsman as an Agent of Accountability." In Holding the Media Accountable: Citizens, Ethics, and the Law. Bloomington: Indiana University Press, 2000.

Nemeth, Neil. "How a Typical American Newspaper Handles Complaints." In Holding the Media Accountable: Citizens, Ethics, and the Law. Bloomington: Indiana University Press, 2000.

Nemeth, Neil. "From Reporting Sleuth to Pioneer in Media Accountability: The Career of the New York World's Isaac D. White." American Journalism. Vol. 25, No. 3, 2008. Pp. 7-29.

Nemeth, Neil, and Sanders, Craig. "Ombudsmen's Interaction with Public Through Columns.” Newspaper Research Journal. Vol. 20, No.1, 1999. Pp. 29-42.

Nemeth, Neil, and Sanders, Craig. "Meaningful Discussion of Performance Missing." Newspaper Research Journal. Vol. 22, No.2, 2001. Pp. 52-64.

Okrent, Daniel. Public Editor \#1: the Collected Columns (with Reflections, Reconsiderations, and Even a Few Retractions) of the First Ombudsman of The New York Times. New York: Public Affairs, 2006.

"Organization of News Ombudsmen Launches New Website." In www.jsource.ca/english_new/detail.php?id=4775 [accessed March 16, 2010].

"Philip M. Foisie's Memos to the Management of the Washington Post." In www.newsombudsmen.org/foisie [accessed October 16, 2009]. 
Plaisance, Patrick Lee. "The Concept of Media Accountability Reconsidered." Journal of Mass Media Ethics. Vol. 15, No.4, 2000. Pp. 257-268.

Pritchard, David. "The Impact of Newspaper Ombudsmen on Journalists' Attitudes." Journalism Quarterly. Vol. 70, No. 1, 1993. Pp. 77-86.

Pritchard, David. "The Process of Media Accountability." In Holding the Media Accountable: Citizens, Ethics, and the Law. Bloomington: Indiana University Press, 2000.

Pritchard, David. "The Future of Media Accountability." In Holding the Media Accountable: Citizens, Ethics, and the Law. Bloomington: Indiana University Press, 2000.

Pritchard, David. "Structural Flaws in Press Council Decision-Making." In Holding the Media Accountable: Citizens, Ethics, and the Law. Bloomington: Indiana University Press, 2000.

Raymond, Linda. "We Were Wrong." In www.newsombudsmen.org/raymond [accessed on March 29, 2009].

Scott, Marvin B., and Lyman, Stanford M. "Accounts." American Sociological Review. Vol. 33, No.1, 1968. Pp. 46-62.

Schedler, Andreas. "Conceptualizing Accountability." In The Self-Restraining State: Power and Accountability in New Democracies. London: Lynne Rienner Publishers, 1999.

Schudson, Michael. Why Democracies Need an Unlovable Press. Cambridge: Polity, 2008.

Shore, Keane. Newspaper Ombudsmen in Canada. Master of Journalism Thesis, Carleton University, 1991.

Stacey, Frank. Ombudsmen Compared. Oxford: Clarendon Press, 1978.

Starck, Kenneth, and Eisele, Julie. "Newspaper Ombudsmanship as Viewed by Ombudsmen and Their Editors." Newspaper Research Journal. Vol. 20, No.4, 1999. Pp. $37-48$.

Tate, Cassandra. "What do ombudsmen do?" Columbia Journalism Review. Vol.23, No.1, 1984. Pp. 37-41.

Van Dalen, Arjen, and Deuze, Mark. "Readers' Advocates or Newspapers' Ambassadors?" European Journal of Communication. Vol. 21, No. 4, 2006. Pp. 457-475.

Wahab, Ibrahim Ismail. The Swedish Institution of Ombudsman: an Instrument of Human Rights. Stockholm: LiberFörlag, 1979. 
Zadec, Simon; Pruzan, Peter, and Evans, Richard. "Why Count Social Performance?" In Building Corporate Accountability: Emerging Practices in Social and Ethical

Accounting, Auditing and Reporting. London: Earthscan Publications Ltd, 1997.

\section{Websites cited}

Canadian Journalism Project (CJP): www.j-source.ca and www.projetj.ca [accessed July $15,2010]$

CBC: www.cbc.ca/ombudsman [accessed February 10, 2010]

Forum of Canadian Ombudsmen: www.ombudsmanforum.ca [accessed March 16, 2010].

Radio Canada: www.radio-canada.ca/ombudsman [accessed February 12, 2010]

Organization of News Ombudsmen: www.newsombudsmen.org [accessed numerous times throughout 2009, and in February and March 2010]

Toronto Star: www.thestar.com/contactus [accessed July 12, 2010]

Merriam-Webster Online Dictionary:

www.merriam-webster.com/dictionary/accountability [accessed August 15, 2009].

Dictionary.com: www.dictionary.reference.com/browse/accountability [accessed August $15,2009]$. 